
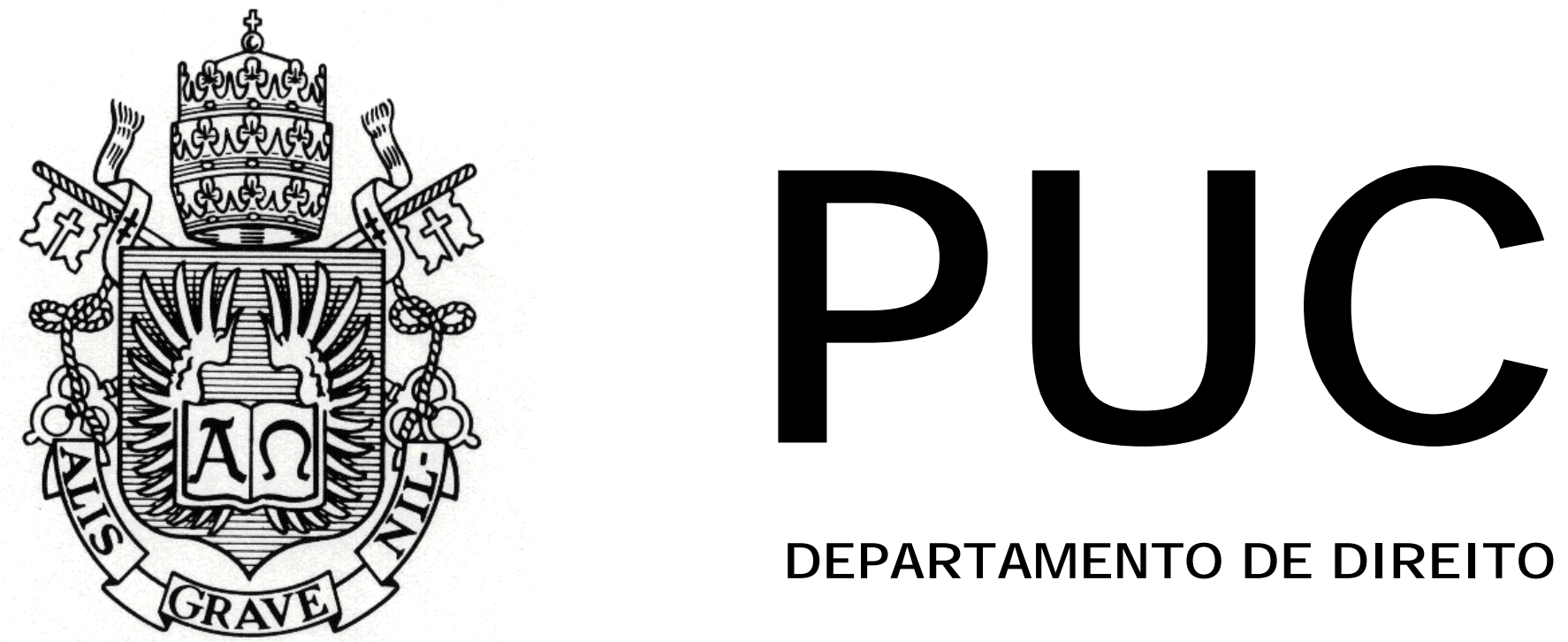

DEPARTAMENTO DE DIREITO

\title{
CONFLITO DE INTERESSES EM ASSEMBLEIA DE SOCIEDADE ANÔNIMA
}

por

Carlos Hugo Galli Hartveld

ORIENTADOR(A): Pedro Paulo Salles Cristofaro 2011.1

PONTIFÍCIA UNIVERSIDADE CATÓLICA DO RIO DE JANEIRO

RUA MARQUÊS DE SÃO VICENTE, 225 - CEP 22453-900

RIO DE JANEIRO - BRASIL 


\title{
CONFLITO DE INTERESSES EM ASSEMBLEIA DE SOCIEDADE ANÔNIMA
}

\author{
por \\ Carlos Hugo Galli Hartveld
}

Monografia apresentada ao Departamento de Direito da Pontifícia Universidade Católica do Rio de Janeiro (PUC-Rio) para a obtenção do Título de Bacharel em Direito.

Orientador(a): Pedro Paulo Salles Cristofaro 
Aos meus pais que tanto se esforçaram para me dar a melhor educação e transmitir os verdadeiros valores da vida. 


\section{RESUMO}

Esta obra tem como escopo a análise da controvérsia em torno da melhor interpretação do termo conflito de interesses constante do parágrafo $1^{\circ}$ do artigo 115 da Lei 6.404/76 ("Lei das S.A.”). Para tal, faz-se necessário o estudo de aspectos preliminares, tais como o interesse social, o voto e o direito de voto. Além disso, em busca da melhor definição, analisa-se cada um dos argumentos fornecidos por ambas as correntes que tratam de explicá-lo, utilizando, para isso, os princípios gerais de direito, o direito comparado, e a interpretação sistemática da Lei das S.A.. Ao final, faz-se um estudo do histórico de entendimentos da Comissão de Valores Mobiliários sobre o tema.

\section{PALAVRAS-CHAVE}

Conflito de Interesses em Assembleia; Parágrafo $1^{\circ}$ do artigo 115 da Lei 6.404/71; Correntes Formal e Material. 


\section{EPÍGRAFE}

"Não existe uma fórmula para o sucesso. Mas, para o fracasso, há uma infalível: tentar agradar a todo mundo."

Herbert Bayard Swope - Editor americano 


\section{ÍNDICE}

INTRODUÇÃO

CAPÍTULO 1: Aspectos Preliminares

1.1. Teorias Sobre o Interesse Social 9

1.2. O Voto e o Direito de Voto 15

CAPÍTULO 2: A Tutela do Interesse Social no Brasil

2.1. Histórico $\quad 19$

2.2. A Lei 6.404 de 1976

CAPÍTULO 3: Correntes Formal e Material

3.1. Correntes Formal e Material 30

3.2. O Conflito 34

3.3. Conflito de Interesses x Proibição de Voto 38

3.4. Conflito de Interesses x Abuso do Direito de Voto 47

3.5. A Inversão do Princípio Majoritário 50

3.6. Abuso das Minorias

3.7. O Princípio da Presunção de Boa-Fé 57

3.8. Conflito de Interesses x Benefício Particular 60

3.9. A Lei 10.303 de 2001

CAPÍTULO 4: A Comissão de Valores Mobiliários 
4.2. Histórico de Decisões da CVM

4.2.1. O Caso TIM

66

4.2.2 O Caso PREVI

70

4.2.3. O Caso AMBEV

73

4.2.4. O Caso TRACTEBEL

76

CONCLUSÃO

BIBLIOGRAFIA

ANEXO 1 


\section{INTRODUÇÃO}

Há muitos temas no direito societário que geraram e continuam a gerar enorme controvérsia entre os doutrinadores. Há poucos, contudo, que apesar de terem instigado tantas mentes, ainda parecem longe de encontrar um consenso. Esta obra tem como escopo justamente um desses debates, mais especificamente, o que gira em torno da melhor interpretação do termo conflito de interesses utilizado no parágrafo $1^{\circ}$ do artigo 115 da Lei 6.404 de 15 de dezembro de 1976 (a "Lei das S.A.”).

Dessa forma, este trabalho não tem a pretensão de trazer uma solução definitiva a essa perseverante polêmica. Objetiva-se aqui, principalmente, apontar e esclarecer os mais importantes pensamentos sobre tal tema. Para isso, são utilizadas ilustrações com os argumentos de cada uma das correntes que tanto se esforçam para explicá-lo.

Assim, esta obra foi estruturada para alcançar os referidos objetivos, sendo que no Capítulo 1 fornecem-se alguns conceitos basilares, primordiais à análise do conflito de interesses. O primeiro deles é o significado do interesse social de acordo com cada uma das correntes que tratam de definí-lo. A segunda análise será acerca do voto e a extensão do direito de exercício do voto.

Mais adiante, no Capítulo 2, adentra-se na interessante busca sobre as origens históricas do conflito de interesses em nosso ordenamento jurídico, evidenciando, consequentemente, os caminhos que percorreu o legislador brasileiro ao optar por redigir a norma constante do parágrafo $1^{\circ}$ do artigo 115 da Lei das S.A., ali também apontada. 
No terceiro Capítulo - central ao debate em pauta - são apresentadas as duas correntes que se esforçam para interpretar a expressão conflito de interesses. Em seguida, são listados os principais alicerces sobre os quais se apóiam essas correntes, a começar pela própria definição do vocábulo conflito. Passa-se, então, ao estudo do Direito Comparado, do instituto do abuso do direito de voto, da importância do Princípio Majoritário e, por fim, deságua-se na caracterização do benefício particular e diferenciação em relação ao conflito de interesses, termo com o qual é muitas vezes confundido.

No último Capítulo desta obra faz-se um breve histórico de decisões da Comissão de Valores Mobiliários (a "CVM") sobre a interpretação do conflito de interesses. Nesse trecho fica evidente o quão controverso é o tema central deste trabalho, dada a diversidade de decisões que tomou a autarquia, pautada sempre em diferentes argumentos.

Ao fim, conclui-se esta obra sem deixar de abordar as implicações práticas da interpretação que decidirmos seguir, principalmente, as econômicas, percebidas no mercado de capitais nacional. 


\section{CAPÍTULO 1 \\ Aspectos Preliminares}

\subsection{Teorias Sobre o Interesse Social}

Interesse deve ser entendido como a relação existente entre um sujeito, que tem uma necessidade qualquer, e determinado bem, apto a satisfazê-la. Entre o sujeito e o bem, assim, forma-se uma relação que, na situação jurídica enfocada, toma o nome de interesse. ${ }^{1}$

E quanto ao interesse social a que se refere o caput do artigo 115 da Lei das S.A. ${ }^{2}$ ? A qual interesse referia-se o legislador ao redigir essa norma? Como pode o acionista identificá-la ao momento do exercício de seu voto?

Basicamente, existem dois grandes grupos que tratam de definir o que seria o interesse social, a saber: os institucionalistas e os contratualistas. ${ }^{3}$ Os primeiros vêem o interesse da companhia como independente ou, ao menos, não totalmente identificado com o interesse dos sócios. ${ }^{4}$ Esse grupo, por sua vez, divide-se entre os seguidores da Teoria da Empresa em Si e os da Teoria da Pessoa em Si.

\footnotetext{
${ }^{1}$ EIZIRIK, Nelson. Temas de Direito Societário. $1^{a}$ ed. Rio de Janeiro: Renovar, 2005. p. 96.

${ }^{2}$ Art. 115. O acionista deve exercer o direito a voto no interesse da companhia; considerar-se-á abusivo o voto exercido com o fim de causar dano à companhia ou a outros acionistas, ou de obter, para si ou para outrem, vantagem a que não faz jus e de que resulte, ou possa resultar, prejuízo para a companhia ou para outros acionistas.

${ }^{3}$ REGO, Marcelo Lamy. Direito das Companhias. $1^{\text {a }}$ ed. Rio de Janeiro: Forense, 2009. v. I, p. 403;

FRANÇA, Erasmo Valladão Azevedo e Novaes. Conflito de Interesses nas Assembléias de S.A.. ed. única São Paulo: Malheiros, 1993. p. 22.

${ }^{4}$ CARVAlHOSA, Modesto de Souza Barros. Comentários à Lei de Sociedades Anônimas. $3^{\mathrm{a}}$ ed. São Paulo: Saraiva, 2003. v. 2, p. 447.
} 
A Teoria da Empresa em Si foi desenvolvida pelo empresário, filósofo, sociólogo e homem de Estado alemão, Walter Rathenau ${ }^{5}$. Sua obra, publicada em 1917, em meio à Primeira Guerra Mundial, era baseada em suas experiências profissionais e alcançou notável repercussão jurídica, em especial, na Alemanha nazista. Rathenau enxergava a importância que as sociedades anônimas haviam alcançado, exercendo vasta influência nos mais variados setores da sociedade, desde nos trabalhadores aos consumidores, passando pela própria comunidade em que atuavam.

É por isso que, para este homem de negócios e seus seguidores, a grande empresa não mais deveria ser tratada como "uma organização de direito privado, mas como um fator da economia nacional, a serviço de interesses públicos". ${ }^{6}$ Era imprescindível, para tanto, libertar o poder de controle da companhia dos limites impostos pelo capital que fora nela investido. O lucro, como consequência lógica, passou a ser desprezado pelos rathenaunianos como fator propulsor da atividade econômica. ${ }^{7}$

Essa liberdade que defendiam os filiados à Rathenau seria alcançada por meio da outorga de amplos poderes aos membros dos órgãos administrativos e ao acionista controlador que os nomeava - este visto como peça chave na

\footnotetext{
${ }^{5}$ Walther Rathenau, judeu nascido em Berlim em 29 de setembro de 1867, morreu assassinado em 24 de junho de 1922; foi um industrial, político, escritor e estadista alemão, que serviu como ministro das Relações Exteriores da Alemanha durante a República de Weimar. Sua obra a respeito do interesse social, Von Aktienwesen (Eine geschaeftliche Betrachtung), foi publicada em Berlim em 1917.

${ }^{6}$ FRANÇA, Erasmo Valladão Azevedo e Novaes. Conflito de Interesses nas Assembléias de S.A.. ed. única São Paulo: Malheiros, 1993. p. 22: "Rathenau chama a atenção, inicialmente, para o que denomina de 'substituição de conteúdo', ou seja, para o fato de que o modelo legal da sociedade anônima de antão regulava um fenômeno completamente diverso, sob todos os ângulos, daquele para o qual fora idealizado, nos primórdios da época industrial. Com aguda percepção da realidade, afirmava ele que a administração das grandes empresas superava, em vários aspectos, a de pequenos Estados. No entanto, essa 'substituição de conteúdo' consistente na passagem da empresa familiar para a grande empresa permanecia ignorada, comportando-se os tribunais segundo esquemas tradicionais. A grande empresa, dizia ele, não é mais uma organização de direito privado, mas um fator da economia nacional, a serviço de interesses públicos".

${ }^{7}$ BORBA, José Eduardo Tavares. Direito Societário. $9^{a}$ ed. Rio de Janeiro: Forense, 2004. p.136
} 
condução dos negócios em favor do interesse público. Limitavam-se, por outro lado, os poderes e a influência da assembleia geral na condução dos negócios sociais. Não poderiam ser mais lúcida a explicação de Modesto Carvalhosa sobre essa matéria:

“(...) a teoria rathenauniana proclama a prevalência do objeto sobre o fim social e, como consequiência, o predomínio dos órgãos administrativos sobre as prerrogativas da assembléia geral, possibilitando o reforço do grupo controlador no contexto societário. Este passa a ser o depositário e o intérprete do interesse social."

Já a Teoria da Pessoa em Si, ou Person na Sich, em alemão, foi fundada com base nos ensinamentos de Otto Friedrich von Gierke ${ }^{9}$. Muito menos radical que a primeira tese, esta não defendia o controle autoritário dos acionistas majoritários ou dos administradores. Ela propunha apenas uma nova visão da pessoa jurídica que passou a ser encarada como uma entidade real com personalidade e interesses próprios. Interesses os quais, inclusive, eram destacados e superiores aos interesses particulares dos sócios. ${ }^{10}$

A consequência maior dessa visão foi que o acionista passou a ser considerado como um órgão da sociedade encarregado de perseguir não seus interesses próprios, mas os interesses sociais. As diferenças entre as duas teorias institucionalistas ficam mais claras após a leitura do seguinte trecho extraído da obra de Erasmo Valladão Azevedo e Novaes França:

"É evidente, porém, a diferença entre as duas doutrinas. Na da pessoa em si, o interesse, reduzido ao da pessoa jurídica, não é externo ao da sociedade. Dessa forma, um dos pilares fundamentais da doutrina da empresa em si, ou seja, o reconhecimento dos interesses públicos na disciplina da sociedade anônima e a

\footnotetext{
${ }^{8}$ CARVAlHOSA, Modesto de Souza Barros. Comentários à Lei de Sociedades Anônimas. $3^{\mathrm{a}}$ ed. São Paulo: Saraiva, 2003. v. II, p. 448.

9 Otto Friedrich von Gierke, nascido em 11 de janeiro de 1841 em Stettin, Alemanha, faleceu em 10 de outubro de 1921 em Berlim; foi um importante jurista alemão. Sua obra mais importante foi Uber die Geschichte dês Majoritatsprinzips.

${ }^{10}$ CARVALHOSA, Modesto de Souza Barros. Comentários à Lei de Sociedades Anônimas. $3^{\text {a }}$ ed. São Paulo: Saraiva, 2003. v. II, p. 448.
} 
outorga de sua tutela aos administradores, cai por terra. Ademais, na concepção organicista de Gierke sobre a pessoa jurídica, os direitos da minoria são protegidos, ao contrário do que ocorre na doutrina da empresa em si, que concede à maioria ampla discriscionariedade na condução dos negócios sociais."11

$\mathrm{Na}$ doutrina brasileira, um dos mais ilustres seguidores da teoria institucionalista é Modesto de Souza Barros Carvalhosa, o que se pode deduzir de suas declarações:

"O interesse social não é, pois, a somatória dos interesses individuais de cada acionista, mas a transcendência desses mesmos interesses por um interesse comum a todos, definido no objetivo empresarial específico da companhia e nos fins sociais que são comuns a todas elas, qual seja, a realização do lucro." 12

Já o grupo dos contratualistas, representados pela Teoria do Interesse Comum, entende que o interesse social da companhia resume-se ao interesse coletivo dos seus sócios. Seus partidários vêem a empresa como uma relação contratual que não envolve outro interesse senão a soma do interesses das partes contratantes. $^{13}$

Para se caracterizar o interesse social é necessária uma zona de interesse comum entre os acionistas, os quais deveriam, por outro lado, manifestar-se em consonância com a realização do objeto social. Ou seja, não se deve confundir o interesse social com qualquer interesse individual dos sócios, mas unicamente identificados com aqueles interesses comuns, mas pertinentes ao objetivo da sociedade.

\footnotetext{
${ }^{11}$ FRANÇA, Erasmo Valladão Azevedo e Novaes. Conflito de Interesses nas Assembléias de S.A.. ed. única São Paulo: Malheiros, 1993. p. 27

${ }^{12}$ CARVALHOSA, Modesto de Souza Barros. Comentários à Lei de Sociedades Anônimas. $3^{\mathrm{a}}$ ed. São Paulo: Saraiva, 2003. v. II, p. 457.

${ }^{13}$ FRANÇA, Erasmo Valladão Azevedo e Novaes. Conflito de Interesses nas Assembléias de S.A.. ed. única São Paulo: Malheiros, 1993. p. 35 e 36.
} 
Como não podia deixar de ser, contudo, existem duas vertentes dentro

dos adeptos ao contratualismo, conforme muito bem definido por Fábio Konder Comparato:

"Deste contratualismo por antonomásia podem-se deduzir duas vertentes diversas: segundo a primeira, o interesse social é depurado de elementos externos. Define-se o interesse social sempre como o interesse dos sócios e somente dos sócios atuais. Pela segunda vertente, incluem-se na categoria de sócio não apenas os atuais, como também os futuros. A perspectiva a longo prazo do interesse social ganha importância. Obviamente, nesse caso, assume relevância também o próprio interesse à preservação da empresa, motivo pelo qual afirma-se que essa variante contratualista, na prática, aproximou-se um pouco da teoria institucionalista.",14

Um dos mais importantes adeptos à corrente contratualista é Túlio Ascarelli, que nega a existência de um interesse social superior ao dos acionistas, conforme citação de Modesto de Souza Barros Carvalhosa:

"As companhias constituem não apenas a comunhão dos interesses, mas, pelo fato de serem voluntárias, também a comunhão dos fins. E é através da constituição contratual de um conjunto de objetivos que se constitui a comunhão de interesses da sociedade (...). O interesse social é entendido como o interesse comum dos sócios e com estes identificado." 15

\section{Junta-se a ele, Fabio Konder Comparato:}

“(...) ainda que teoricamente discutível e sua prática muitas vezes superada, o contratualismo revive e predomina na interpretação doutrinária e jurisprudencial (...). Ora, não existem em direito interesses e relações que não digam respeito unicamente aos homens. Por conseguinte, toda a disciplina jurídica concernente às pessoas jurídicas reduz-se, finalmente, a uma disciplina de interesses dos homens que as compõem, uomini nati ventre di donna, como enfatizava. $\mathrm{O}$ chamado interesse social não pode deixar de ser o dos sócios e somente deles. Toda e qualquer hipóstase, aí, é de rejeitar-se. (...) As sociedades por ações, tal como as demais sociedades, reduzemse, à categoria dos contratos plurilaterais."

${ }^{14}$ COMPARATO, Fabio Konder; SALOMÃo FILHO, Calixto. O Poder de Controle na Sociedade Anônima. $4^{\mathrm{a}}$ ed. Rio de Janeiro: Forense. p. 331.

${ }^{15}$ CARVALHOSA, Modesto de Souza Barros. Comentários à Lei de Sociedades Anônimas. $3^{\mathrm{a}}$ ed. São Paulo: Saraiva, 2003. v. II, p. 452.

${ }^{16}$ COMPARATO, Fabio Konder; SALOMÃO FILHO, Calixto. O Poder de Controle na Sociedade Anônima. $4^{\text {a }}$ ed. Rio de Janeiro: Forense. p. 331. 
Ainda que filiado à doutrina contratualista, Fabio Konder Comparato nos ensina que teria prevalecido na Lei das S.A. a corrente institucionalista. Exemplo disso seria o parágrafo único do artigo $116^{17}$, que determina que o acionista controlador deve usar o poder atendendo e respeitando os direitos e interesses dos trabalhadores e da comunidade. Outro exemplo estaria na alínea $a$ do parágrafo $1^{\circ}$ do artigo $117^{18}$, ao utilizar os termos interesse nacional e economia nacional para qualificar formas de exercício abusivo de voto. Ou, ainda, o disposto no artigo $154^{19}$ da lei societária, que condiciona o exercício da administração à satisfação das "exigências do bem público e da função social da empresa". ${ }^{20}$ No mesmo sentido, José Eduardo Tavares Borba. ${ }^{21}$

José Luiz Bulhões Pedreira e Alfredo Lamy Filho discordam desse posicionamento, pois afirma que:

\begin{abstract}
"O direito positivo brasileiro também não enseja dúvidas sobre a natureza contratual da companhia. (...) A LSA admite expressamente a natureza contratual, ao dispor (no art. 83) que o 'projeto de estatuto deverá satisfazer a todos os requisitos exigidos para os contratos das sociedades mercantis em geral e aos peculiares às companhias, e conterá as normas pelas quais se regerá a companhia."”22
\end{abstract}

\footnotetext{
${ }^{17}$ Art. 116 (...) Parágrafo único. O acionista controlador deve usar o poder com o fim de fazer a companhia realizar o seu objeto e cumprir sua função social, e tem deveres e responsabilidades para com os demais acionistas da empresa, os que nela trabalham e para com a comunidade em que atua, cujos direitos e interesses deve lealmente respeitar e atender.

${ }^{18}$ Art. 117 (...) $\S 1^{\circ}$ São modalidades de exercício abusivo de poder: a) orientar a companhia para fim estranho ao objeto social ou lesivo ao interesse nacional, ou levá-la a favorecer outra sociedade, brasileira ou estrangeira, em prejuízo da participação dos acionistas minoritários nos lucros ou no acervo da companhia, ou da economia nacional;

${ }^{19}$ Art. 154. O administrador deve exercer as atribuições que a lei e o estatuto lhe conferem para lograr os fins e no interesse da companhia, satisfeitas as exigências do bem público e da função social da empresa.

${ }^{20}$ COMPARATO, Fabio Konder; SALOMÃO FILHO, Calixto. O Poder de Controle na Sociedade Anônima. $4^{\mathrm{a}}$ ed. Rio de Janeiro: Forense. p. 371.

${ }^{21}$ BORBA, José Eduardo Tavares. Direito Societário. $9^{\mathrm{a}}$ ed. Rio de Janeiro: Renovar, 2004. p. 135: “A Lei 6.404/76, numa demonstração de que a sociedade anônima é uma verdadeira instituição, depois de conceituar o acionista controlador, determina (art. 116, parágrafo único) que este deve usar seu poder 'para fazer a companhia realizar seu objeto social e cumprir sua função social', acrescentando que 'tem deveres e responsabilidades para com os demais acionistas da empresa, os que nela trabalham e para com a comunidade em que atua, cujos direitos e interesses deve lealmente respeitar e atender'."

${ }^{22}$ BULHÕES PEDREIRA, José Luiz; LAMY FILHO, Alfredo. Direito das Companhias. $1^{\mathrm{a}}$ ed. Rio de Janeiro: Forense, 2009. v. I, p. 91 e 92.
} 
Já Luiz Antonio de Sampaio Campos encontra um meio termo ao defender que "a LSA possui tanto características institucionais quanto contratuais, não se filiando exclusivamente a uma ou outra corrente". ${ }^{23}$

\title{
1.2. O Voto e o Direito de Voto
}

O voto é o meio de manifestação da vontade do acionista em assembleia geral. É por meio dele que se afere a vontade ou o entendimento predominante entre os acionistas com direito de participar das deliberações sociais e, por conseguinte, se determina o que seria o interesse social da companhia. ${ }^{24}$ Nesse sentido, vale apresentar aqui o posicionamento de Wilson de Souza Campos Batalha, citado por Marcelo Lamy Rego:

\begin{abstract}
"Na lição de Campos Batalha 'o voto constitui declaração unilateral de vontade destinada à formação de vontade do órgão social, obedecidos os pressupostos legais. A vontade declarada individualmente pelos acionistas, uma vez preenchidos os requisitos de regular instalação da assembléia, de quorum, de maioria legal e de validade da declaração individual, passa a constituir manifestação de vontade da assembléia geral, imputável à sociedade como ente juridicamente diverso dos acionistas'., 25
\end{abstract}

Ressalte-se, contudo, que existem diferentes tipos de voto. $\mathrm{O}$ voto pode ser tanto de vontade como de verdade. No primeiro caso, o acionista escolhe, dentre as opções que lhe foram apresentadas na assembleia, qual das alternativas mais the interessa. No segundo caso, ele reconhece a fidelidade ou veracidade de um documento em apreciação ao seu correspondente objeto. ${ }^{26}$ Vejamos alguns exemplos, nas palavras de Carvalhosa:

\footnotetext{
${ }^{23}$ CAMPOS, Luiz Antonio Sampaio. Direito das Companhias. $1^{\mathrm{a}}$ ed. Rio de Janeiro: Forense, 2009. v. I, p. 1159.

${ }^{24}$ COELHO, Fábio Ulhoa. Curso de Direito Comercial. $8^{a}$ ed. São Paulo: Saraiva, 2005. v. II, p. 308.

${ }^{25}$ REGO, Marcelo Lamy. Direito das Companhias. $1^{\mathrm{a}}$ ed. Rio de Janeiro: Forense, 2009. v. I, p. 380.

${ }^{26}$ COELHO, Fabio Ulhoa. Curso de Direito Comercial. $8^{a}$ ed. São Paulo: Saraiva, 2005. v. II, p. 309.
} 
“(...) será o voto um ato de vontade na medida em que o acionista deliberar, v.g., sobre o aumento de capital social ou qualquer outra alteração estatutária. Ou, ainda, quando deve decidir sobre a eleição e/ou destituição de um administrador, ou sobre a fusão ou a cisão da companhia, ou qualquer outra forma de modificação institucional dela. Será, por outro lado, um mero ato de verdade, quando o objeto do voto for, v.g., a aprovação do relatório das contas e do balanço apresentado ordinariamente pelos órgãos da administração." ${ }^{27}$

$\mathrm{O}$ direito de voto, por outro lado, é justamente o direito de exercer o voto. De acordo com Alfredo Lamy Filho e José Luiz Bulhões Pedreira, o direito de voto é o meio pelo qual o acionista participa das deliberações da assembleia geral e pode contribuir, por meio da manifestação da sua vontade, para a formação da vontade social. Em outras palavras, o direito de voto seria o instrumento para o desempenho do acionista enquanto membro do órgão social. $^{28}$ Nas palavras de Marcelo Lamy Rego:

"Direito de voto é o direito do acionista de manifestar sua vontade na assembléia geral, a favor ou contra a aprovação de proposta de deliberação, e de ter seu voto computado na formação da vontade social." 29

O exercício do direito de voto deve, ainda, ser entendido como um direito subjetivo, sujeito ao princípio da liberdade, podendo, para tanto, o acionista exercê-lo ou se abster de fazê-lo.

Destaque-se, contudo, que diferentemente da discricionariedade que é concedida à decisão sobre exercer ou não o voto, no que tange ao conteúdo desse voto, existem limites claros impostos pelo ordenamento jurídico brasileiro. O melhor exemplo de tal afirmação constata-se por meio da leitura do caput artigo $115^{30}$ da Lei das S.A. que, como dito anteriormente, impõe ao

${ }^{27}$ CARVAlHOSA, Modesto de Souza Barros. Comentários à Lei de Sociedades Anônimas. $3^{\mathrm{a}}$ ed. São Paulo: Saraiva, 2003. v. II, p. 387.

${ }^{28}$ BULHÕES PEDREIRA, José Luiz; LAMY FILHO, Alfredo. A Lei das S.A...1 ed. Rio de Janeiro: Renovar. v. II, p. 456.

${ }^{29}$ REGO, Marcelo Lamy. Direito das Companhias. $1^{\text {a }}$ ed. Rio de Janeiro: Forense, 2009. v. I, p. 377.

${ }^{30}$ Art. 115. O acionista deve exercer o direito a voto no interesse da companhia; considerar-se-á abusivo o voto exercido com o fim de causar dano à companhia ou a outros acionistas, ou de obter, 
acionista o dever de exercer o seu direito de voto no interesse social. Como bem observado por Modesto de Souza Barros Carvalhosa, existe sim, de acordo com nossa lei societária, uma conotação social no conteúdo do voto:

\begin{abstract}
"Trata-se, pois, de um direito próprio com profunda conotação social ou coletiva, na medida em que, instrumentalmente, é destinado a formar a vontade do grupo de controle ou dos minoritários, e de cujo exercício coletivo resulta formada a vontade social.", ${ }^{31}$
\end{abstract}

Já de acordo com os ensinamentos de Alfredo Lamy Filho e José Luiz Bulhões Pedreira, existiria um direito-função intrinsecamente ligado ao exercício do voto:

“(...) Ao prescrever o exercício do direito de voto no interesse da companhia, a lei proíbe ao acionista colocar a serviço de qualquer outro papel que ocupe um poder jurídico que é conferido para o desempenho da função de membro da Assembleia Geral. A caracterização do direito de voto como um 'direito-função' e a distinção entre os atos do acionista enquanto sócio e como pessoa são outros modos de exprimir o mesmo princípio." 32

A lei societária brasileira busca, assim, afastar o direito de voto de seu caráter subjetivo, aproximando-o a um direito-dever, conferindo um poder ao seu titular para agir no interesse de outrem e não em seu interesse próprio. A princípio, essa limitação do conteúdo do voto pode parecer-nos uma afronta à liberdade de manifestação do acionista. No entanto, a partir de uma análise mais aprofundada, percebe-se que o direito de voto assemelha-se, em alguns aspectos, à potestas do direito romano, já que é um poder jurídico conferido ao seu titular para agir no interesse de outrem, neste caso, a sociedade. ${ }^{33}$

para si ou para outrem, vantagem a que não faz jus e de que resulte, ou possa resultar, prejuízo para a companhia ou para outros acionistas.

${ }^{31}$ CARVALHOSA, Modesto. Comentários à Lei de Sociedades Anônimas. $3^{\mathrm{a}}$ ed. São Paulo: Saraiva, 2003. v. II, p. 386.

${ }^{32}$ BULHÕES PEDREIRA, José Luiz; LAMY FILHO, Alfredo. A Lei das S.A.. $1^{\mathrm{a}}$ ed. Rio de Janeiro: Renovar, 1992. v. III, p. 456.

${ }^{33}$ REGO, Marcelo Lamy. Direito das Companhias. $1^{\text {a }}$ ed. Rio de Janeiro: Forense. v. I, p. 378. 
Essa função social do voto decorre, primordialmente, da influência exercida pela corrente institucionalista na elaboração da Lei das S.A.. O legislador, nesse sentido, viu a necessidade de proteger o interesse maior da sociedade frente ao interesse dos sócios que a representam. Exige-se deles, por isso, um distanciamento de seu interesse próprio quando do exercício do voto assemblear que deve sempre focar o interesse social.

Fabio Konder Comparato justifica a atitude do legislador ao afirmar que "a todo poder correspondem deveres e responsabilidades próprias, exatamente porque se trata de um direito-função, atribuído ao titular para a consecução de finalidade precisas". ${ }^{34}$

Por fim, vale mencionar que o direito de voto não é, tal qual o direito de participar dos lucros ou o de fiscalizar, um direito essencial do acionista. Se de outra forma fosse, estaria enquadrado no artigo 109 da Lei das S.A. ${ }^{35}$. Pode esse direito, inclusive, ser suprimido pelo estatuto social, desde que, de acordo com a lei, se garanta alguma contrapartida político-financeira. As ações preferenciais sem direito de voto são o maior exemplo disso. Outra hipótese nos é trazida pelo artigo $120^{36}$ da lei societária que prescreve que a assembleia geral poderá suspender direitos, inclusive o de voto, dos acionistas que deixarem de cumprir com suas obrigações legais ou estatutárias. ${ }^{37}$

\footnotetext{
${ }^{34}$ COMPARATO, Fabio Konder; SALOMÃO FILHO, Calixto. O Poder de Controle na Sociedade Anônima. $4^{\text {a }}$ ed. Rio de Janeiro: Forense. p. 363.

${ }^{35}$ Art. 109. Nem o estatuto social nem a assembléia-geral poderão privar o acionista dos direitos de: I participar dos lucros sociais; II - participar do acervo da companhia, em caso de liquidação; III fiscalizar, na forma prevista nesta Lei, a gestão dos negócios sociais; IV - preferência para a subscrição de ações, partes beneficiárias conversíveis em ações, debêntures conversíveis em ações e bônus de subscrição, observado o disposto nos artigos 171 e 172; V - retirar-se da sociedade nos casos previstos nesta Lei.

${ }^{36}$ Art. 120. A assembléia-geral poderá suspender o exercício dos direitos do acionista que deixar de cumprir obrigação imposta pela lei ou pelo estatuto, cessando a suspensão logo que cumprida a obrigação.

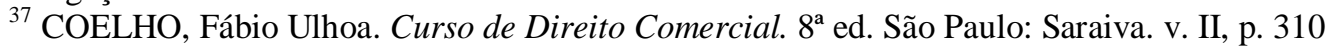




\section{CAPÍTULO 2 \\ A Tutela do Interesse Social no Brasil}

\subsection{Histórico}

Como muito bem dito nas lições de Fabio Ulhoa Coelho, as sociedades anônimas correspondem à forma jurídico-societária mais apropriada aos grandes empreendimentos econômicos. Existem dois motivos para isso. O primeiro deles é a limitação de responsabilidades dos sócios frente às obrigações da pessoa jurídica. O segundo, não menos importante, é a liquidez das ações representativas do capital social investido. ${ }^{38}$ É isso que permite a essas empresas mobilizarem as poupanças de milhares de pessoas para aplicálas em projetos de monta. A consequência prática é a enorme influência social, econômica e política das sociedades anônimas, o que, por sua vez, acarreta a natural preocupação de regulamentação de sua atividade pelo Estado.

Segundo os ensinamentos de José Eduardo Tavares Borba, ao longo da História, a sociedade anônima conheceu três sistemas distintos para a sua constituição. Primeiramente, nos séculos XVII e XVIII, vigorou o sistema de privilégios. A criação de uma sociedade anônima nessa época dependia de um ato de governo. Posteriormente, a partir da promulgação do Decreto 575, passou-se ao sistema de autorização, pelo qual a criação de uma sociedade por ações dependia de preliminar autorização do Governo. ${ }^{39}$

Somente em 4 de novembro de 1882, data da publicação da Lei 3.150, a constituição das sociedades anônimas foi totalmente alforriada. ${ }^{40}$ Foi essa

\footnotetext{
${ }^{38}$ COELHO, Fábio Ulhoa. Curso de Direito Comercial. $8^{\text {a }}$ ed. São Paulo: Saraiva. v. II, p. 59.

${ }^{39}$ FRANÇA, Erasmo Valladão Azevedo e Novaes. Conflito de Interesses nas Assembléias de S.A.. ed. única São Paulo: Malheiros, 1993. p. 68

${ }^{40}$ BORBA, José Eduardo Tavares. Direito Societário. 9a ed. Rio de Janeiro: Renovar. p. 133 e 134;
} 
mesma lei que, regulada pelo Decreto $\mathrm{n}^{\circ}$ 8.821, instaurou no Brasil o chamado Regime de Regulamentação ou das Disposições Normativas. Livres do rígido controle estatal era natural, contudo, que o legislador passasse a se preocupar mais enfaticamente em criar mecanismos para proteger o interesse da companhia nas deliberações assembleares. ${ }^{41}$

Foi nesse contexto que se editou o artigo 12 da referida Lei 3.150. Essa norma inovou ao trazer o conceito de interesse oposto, predecessor do conflito de interesses no nosso ordenamento jurídico atual. O legislador fez neste tópico menção expressa ao interesse da companhia como critério genérico orientador do direito de voto. Era, contudo, voltada especificamente ao administrador da sociedade:

“Art. 12. O administrador, que tiver interesse opposto ao da companhia, em qualquer operação social, não poderá tomar parte na deliberação a respeito, e será obrigado a fazer o necessário aviso aos outros administradores, devendo disso lavrar-se declaração na acta das sessões." ${ }^{, 2}$ (sic) (grifou-se)

Já no que tange às disposições relativas aos acionistas em geral, o legislador não aplicou a regra da generalidade; ao contrário, definiu critérios objetivos e bastante específicos para determinar os casos de proibição do exercício do direito de voto. Veja-se abaixo o parágrafo 10 do artigo 15 dessa mesma lei:

“\$10. Não podem votar nas assembléas geraes os administradores para approvarem seus balanços, contas e inventarios, os fiscaes os seus pareceres, e os accionistas a

Lei 3.150. Art. $1^{\circ}$. As companhias ou sociedades anonymas, quer o seu objecto seja commercial quer civil, se podem estabelecer sem autorização do Governo. Disponível no site do Planalto <http://www.planalto.gov.br/ccivil_03/LEIS/1851-1900/L3150.htm>. Acesso em 10 de maio de 2011

${ }^{41}$ FRANÇA, Erasmo Valladão Azevedo e Novaes. Conflito de Interesses nas Assembléias de S.A.. ed. única São Paulo: Malheiros, 1993. p. 69

${ }^{42}$ Disponível no site do Planalto <http://www.planalto.gov.br/ccivil_03/LEIS/1851-1900/L3150.htm>. Acesso em 10 de maio de 2011. 
avaliação de seus quinhões, ou quaesquer vantagens estipuladas nos estatutos ou contrato social., $" 43$ (sic)

Com a proclamação da República, foi publicado, em 1890, o Decreto 164 que reformou a Lei 3.150 deixando, apesar disso, praticamente intacta a redação original do artigo 12 e do parágrafo 10 do artigo 15. Outros diplomas legais sobre a matéria foram editados nos anos subsequentes: os Decretos 997 de 1890, 1.362 de 1891, 1.386 de 1981 e 434. Nenhum deles, todavia, trouxe quaisquer mudanças relevantes no que tange às situações conflituosas. Continuou-se, portanto, sem uma disposição genérica de proteção ao interesse da companhia em deliberações assembleares capazes de atingir, inclusive, o acionista não administrador. ${ }^{44}$

Não foi até 26 de setembro de 1940, data da promulgação do Decreto-lei 2.627, que regulamentava a constituição e funcionamento das sociedades por ações, apresentado por Trajano de Miranda Valverde em plena Era Vargas, que a proteção do interesse social no âmbito das assembleias gerais ganharia novos contornos. Eram quatro os itens que tratavam sobre o tema, a saber, os artigos $82,95,100$ e 120.

\footnotetext{
${ }^{43}$ Disponível no site do Planalto <http://www.planalto.gov.br/ccivil_03/LEIS/1851-1900/L3150.htm>. Acesso em 10 de maio de 2011.

${ }^{44}$ FRANÇA, Erasmo Valladão Azevedo e Novaes. Conflito de Interesses nas Assembléias de S.A.. ed. única São Paulo: Malheiros, 1993. p. 71 e 72:

Não obstante o silêncio da lei, ilustres juristas contemporâneos, tais como Manuel Inácio Carvalho de Mendonça, já se indagavam se haveria alguma obrigação do acionista abster-se de votar em situações de conflito com a sociedade: "o acionista pode votar sobre negócio que lhe diga respeito e que porventura contrate com a sociedade? Poderá votar em si mesmo para os cargos de administrador ou fiscal? A opinião geral é que a lei não vedando, implicitamente permite que vote o acionista, ainda que seja administrador. As proibições são de direito estrito. Os votos dos outros acionistas podem eliminar a influência dos votos dos interessados. Que lucraria a lei estabelecendo a proibição se não evitar aos acionistas transferirem as ações a figuras de palha para a votação nas assembléias? É melhor que cada um assuma francamente a responsabilidade de seus atos. (...) muitas vezes é difícil precisar os interesses opostos entre o administrador e a sociedade. Só a apreciação do caso concreto oferece a justa solução"
} 
Na nova lei, o conteúdo do antigo parágrafo 10 do artigo 15 da Lei 3.150 foi dividido em dois dispositivos. A primeira parte, inserida no artigo 82, tratava dos acionistas em geral. Já o artigo 100 cuidava do exercício do voto do administrador quando deliberada a aprovação das suas contas. Ambos os dispositivos transcritos abaixo:

“Art. 82. O acionista não pode votar nas deliberações da assembléia geral relativas ao laudo de avaliação dos bens com que concorrer para a formação do capital social, nem nas que venham a beneficiá-lo de modo particular."45

“Art. 100. Instalada a assembléia geral proceder-se-á à leitura do relatório, do balanço, da conta de lucros e perdas e do parecer do conselho fiscal. O presidente abrirá, em seguida, discussão sobre esses documentos e, encerrada, submeterá a votação as contas da diretoria, o balanço e o parecer do conselho fiscal. Não poderão tomar parte na votação os membros da diretoria e do conselho fiscal." ${ }^{46}$

Note-se que houve, contudo, uma ligeira extensão do alcance da norma do artigo 82 do Decreto-Lei 2.627, visto que, ao contrário do parágrafo 10 do artigo 15 da Lei 3.150, o acionista estava impedido de votar sobre quaisquer vantagens, independente de estarem ou não previstas no estatuto social.

Outro avanço do Decreto-Lei 2.627, foi trazido pela redação do artigo 95. Nele o legislador incluiu, pela primeira vez em nosso ordenamento jurídico, uma norma genérica de proteção do interesse da companhia nas deliberações assembleares capazes de nortear o voto de qualquer acionista e não só dos administradores. ${ }^{47}$ Veja-se a redação, com especial atenção ao trecho em destaque:

\footnotetext{
45 Disponível no site do Planalto < http://www.planalto.gov.br/ccivil/Decreto-Lei/Del2627.htm>. Acesso em 10 de maio de 2011.

46 Disponível no site do Planalto < http://www.planalto.gov.br/ccivil/Decreto-Lei/Del2627.htm>. Acesso em 10 de maio de 2011.

${ }^{47}$ FRANÇA, Erasmo Valladão Azevedo e Novaes. Conflito de Interesses nas Assembléias de S.A.. ed. única São Paulo: Malheiros, 1993. p. 73
} 
“Art. 95. Responderá por perdas e danos o acionista que tendo em uma operação interesses contrários aos da sociedade, votar deliberação que determine com o seu voto a maioria necessária." ${ }^{, 48}$ (grifou-se)

Percebe-se que a expressão interesse opposto foi substituída pelo termo interesses contrários. A inclusão da referida norma não veio acompanhada, contudo, do significado dessa expressão, o que gerou um acalorado debate entre os juristas da época sobre o seu alcance. Referiam-se a questões materiais ou meramente formais? De acordo com Erasmo Valladão Azevedo e Novaes França que cita Trajano de Miranda Valverde, Francisco Cavalcanti Pontes de Miranda e Ruy Carneiro Guimarães, o interesse contrário seria uma questão de fato a ser analisada caso a caso. O artigo 95, portanto, diferentemente do que estipulava o anteprojeto da lei, não impedia expressamente o acionista de tomar parte na deliberação assemblear, mas apenas estabelecia uma sanção na hipótese ali prevista. ${ }^{49}$

Por fim, vale aqui citar a redação do artigo 120 do mesmo Decreto-Lei 2.627, que, a exemplo do artigo 12 da Lei 3.150, limitava a atuação do administrador em situações de interesse oposto ao da companhia, sem trazer, todavia, qualquer avanço em relação ao dispositivo anterior:

“Art. 120. É vedado ao diretor intervir em qualquer operação social, em que tenha interesse oposto ao da companhia, bem como na deliberação que a respeito tomarem os demais diretores, cumprindo-lhe cientificá-los do seu impedimento." ${ }^{, 50}$ (grifou-se)

A tutela dos interesses sociais da sociedade anônima frente às situações de conflitos de interesse permaneceu sem mudanças até 15 de dezembro de 1976, data da promulgação da Lei 6.404, chamada de a nova Lei das

\footnotetext{
48 Disponível no site do Planalto < http://www.planalto.gov.br/ccivil/Decreto-Lei/Del2627.htm>. Acesso em 10 de maio de 2011.

${ }^{49}$ FRANÇA, Erasmo Valladão Azevedo e Novaes. Conflito de Interesses nas Assembléias de S.A.. ed. única São Paulo: Malheiros, 1993. p. 74.

50 Disponível no site do Planalto < http://www.planalto.gov.br/ccivil/Decreto-Lei/Del2627.htm>. Acesso em 10 de maio de 2011.
} 
Sociedades Anônimas brasileira. A partir de então, o debate sobre o conflito de interesses ganharia novos contornos já que passou a ser mais amplamente tutelado pelo legislador e, posteriormente, inclusive pela CVM, criada naquele mesmo ano.

\subsection{A Lei 6.404 de 1976}

Passados os tempos do laissez faire, laissez passer, ganha força no Brasil e no mundo o fenômeno jurídico pelo qual, cada vez mais, leis de Direito Privado, têm, não apenas se limitado a regular certa atividade, mas lançado mão de dispositivos com o claro objetivo de proteger uma das partes. Baseadas no Princípio da Equidade e conscientes da diferenciação de poderes entre os contratantes, essas leis permeiam diversas áreas do nosso ordenamento jurídico, tais como o Direito do Trabalho, o Direito do Consumidor e até o Direito de Família. Não cabe aqui explorar esses ramos, já que não fazem parte do escopo desta obra; restringir-se-á o estudo, portanto, à Lei das Sociedades Anônimas. ${ }^{51}$

A Lei 6.404 de 15 de dezembro de 1976, inspirada nas correntes institucionalistas, apresenta claramente uma preocupação focada não só na proteção dos acionistas minoritários, mas também na tutela do interesse da própria sociedade anônima. Dentre os dispositivos mais importantes dos quais o legislador se utilizou para alcançar esse fim, está o caput do artigo 115, que

\footnotetext{
${ }^{51}$ Nesse sentido, a exposição de motivos $n^{\circ}$ 196, de 24 de junho de 1976 para a Lei das S.A.: "O Projeto visa basicamente a criar a estrutura jurídica necessária ao fortalecimento do mercado de capitais de risco no País, imprescindível à sobrevivência da empresa privada na fase atual da economia brasileira. A mobilização da poupança popular e o seu encaminhamento voluntário para o setor empresarial exigem, contudo, o estabelecimento de uma sistemática que assegure ao acionista minoritário o respeito a regras definidas e eqüitativas, as quais, sem imobilizar o empresário em suas iniciativas, ofereçam atrativos suficientes de segurança e rentabilidade." (grifou-se). Disponível no site da CVM <http://www.cvm.gov.br/port/atos/leis/6404_Exposicao.asp>. Acesso em 10 de maio de 2011.
} 
determina como deve ser orientado o voto de qualquer acionista em assembleia. Além dele, o parágrafo único do artigo $116^{52}$ e o parágrafo $1^{\circ}$ do artigo $117^{53}$, que tratam do uso e abuso do poder de controle pelo acionista controlador. Podem ainda ser citados os artigos $154^{54}$, 156 e $245^{55}$, que protegem o interesse social face à conduta do administrador, dentre outros.

No que tange especificamente ao conflito de interesses, há duas normas que valem ser destacadas. A primeira delas é a constante do artigo 156, que trata da situação conflituosa entre administrador e companhia. Como se pode ver abaixo, a redação deste dispositivo é praticamente idêntica à do artigo 120 do Decreto-Lei 2.627 que fora revogado:

\footnotetext{
52 Art. 116. (...) Parágrafo único. O acionista controlador deve usar o poder com o fim de fazer a companhia realizar o seu objeto e cumprir sua função social, e tem deveres e responsabilidades para com os demais acionistas da empresa, os que nela trabalham e para com a comunidade em que atua, cujos direitos e interesses deve lealmente respeitar e atender.

${ }_{53}$ Art. 117. (...) $\S 1^{\circ}$ São modalidades de exercício abusivo de poder: a) orientar a companhia para fim estranho ao objeto social ou lesivo ao interesse nacional, ou levá-la a favorecer outra sociedade, brasileira ou estrangeira, em prejuízo da participação dos acionistas minoritários nos lucros ou no acervo da companhia, ou da economia nacional; b) promover a liquidação de companhia próspera, ou a transformação, incorporação, fusão ou cisão da companhia, com o fim de obter, para si ou para outrem, vantagem indevida, em prejuízo dos demais acionistas, dos que trabalham na empresa ou dos investidores em valores mobiliários emitidos pela companhia; c) promover alteração estatutária, emissão de valores mobiliários ou adoção de políticas ou decisões que não tenham por fim o interesse da companhia e visem a causar prejuízo a acionistas minoritários, aos que trabalham na empresa ou aos investidores em valores mobiliários emitidos pela companhia; d) eleger administrador ou fiscal que sabe inapto, moral ou tecnicamente; e) induzir, ou tentar induzir, administrador ou fiscal a praticar ato ilegal, ou, descumprindo seus deveres definidos nesta Lei e no estatuto, promover, contra o interesse da companhia, sua ratificação pela assembléia-geral; f) contratar com a companhia, diretamente ou através de outrem, ou de sociedade na qual tenha interesse, em condições de favorecimento ou não equitativas; g) aprovar ou fazer aprovar contas irregulares de administradores, por favorecimento pessoal, ou deixar de apurar denúncia que saiba ou devesse saber procedente, ou que justifique fundada suspeita de irregularidade. h) subscrever ações, para os fins do disposto no art. 170, com a realização em bens estranhos ao objeto social da companhia.

${ }^{54}$ Art. 154. O administrador deve exercer as atribuições que a lei e o estatuto lhe conferem para lograr os fins e no interesse da companhia, satisfeitas as exigências do bem público e da função social da empresa.

55 Art. 245. Os administradores não podem, em prejuízo da companhia, favorecer sociedade coligada, controladora ou controlada, cumprindo-lhes zelar para que as operações entre as sociedades, se houver, observem condições estritamente comutativas, ou com pagamento compensatório adequado; e respondem perante a companhia pelas perdas e danos resultantes de atos praticados com infração ao disposto neste artigo.
} 
“Art. 156. É vedado ao administrador intervir em qualquer operação social em que tiver interesse conflitante com o da companhia, bem como na deliberação que a respeito tomarem os demais administradores, cumprindo-lhe cientificá-los do seu impedimento e fazer consignar, em ata de reunião do conselho de administração ou da diretoria, a natureza e extensão do seu interesse. ${ }^{, 56}$ (grifou-se)

Em segundo lugar, está o parágrafo $1^{\circ}$ do artigo 115 , objeto central do estudo desta obra. Nele, pela primeira vez, o ordenamento jurídico brasileiro determinou expressamente que o direito de voto de qualquer dos acionistas deveria ser exercido somente se em favor dos interesses da própria companhia. Este dispositivo acrescentou às situações já previstas na Lei 3.150 e no Decreto-Lei 2.627 o impedimento de voto em circunstâncias generalistas de conflito de interesses, antes restrito apenas aos conflitos envolvendo os administradores da sociedade, conforme já visto. Para melhor se desdobrar a análise desta matéria, veja-se a seguir a íntegra do dispositivo legal:

"Art. 115. O acionista deve exercer o direito a voto no interesse da companhia; considerar-se-á abusivo o voto exercido com o fim de causar dano à companhia ou a outros acionistas, ou de obter, para si ou para outrem, vantagem a que não faz jus e de que resulte, ou possa resultar, prejuízo para a companhia ou para outros acionistas.

$\S 1^{\circ} \mathrm{O}$ acionista não poderá votar nas deliberações da assembléia-geral relativas ao laudo de avaliação de bens com que concorrer para a formação do capital social e à aprovação de suas contas como administrador, nem em quaisquer outras que puderem beneficiá-lo de modo particular, ou em que tiver interesse conflitante com o da companhia.

$\S 2^{\circ}$ Se todos os subscritores forem condôminos de bem com que concorreram para a formação do capital social, poderão aprovar o laudo, sem prejuízo da responsabilidade de que trata o $\S 6^{\circ}$ do artigo $8^{\circ}$.

$\S 3^{\circ} \mathrm{O}$ acionista responde pelos danos causados pelo exercício abusivo do direito de voto, ainda que seu voto não haja prevalecido.

$\S 4^{\circ}$ A deliberação tomada em decorrência do voto de acionista que tem interesse conflitante com o da companhia é anulável; o acionista responderá pelos danos

56 Disponível no site do Planalto <http://www.planalto.gov.br/ccivil/Decreto-Lei/Del2627.htm>. Acesso em 10 de maio de 2011. 
causados e será obrigado a transferir para a companhia as vantagens que tiver auferido." ${ }^{\mathrm{5} 7}$

Como visto, o texto do parágrafo $1^{\circ}$ proíbe o exercício do direito de voto dos acionistas em assembleia geral em quatro hipóteses distintas: (i) na votação do laudo de avaliação dos bens por eles utilizados para formação do capital $\operatorname{social}^{58}$; (ii) caso sejam administradores, na aprovação das suas contas ${ }^{59}$; (iii) em situações que puderem lhe trazer um benefício não compartilhado com os demais acionistas ${ }^{60}$; e, por último, (iv) nas situações de conflito de interesse.

Quanto à proibição de voto nas duas primeiras situações, tanto a doutrina como a jurisprudência são unânimes no reconhecimento de tal impedimento a priori, baseados em um conflito aparente, determinado por fatores meramente objetivos. ${ }^{61}$ Isto com base no Princípio Nemo Iudex in Causa Propria, que se traduz pelo preceito de que a ninguém é licito julgar

${ }^{57}$ Disponível no site do Planalto <http://www.planalto.gov.br/ccivil/leis/L6404consol.htm>. Acesso em 10 de maio de 2011.

${ }^{58}$ Art. $7^{\circ} \mathrm{O}$ capital social poderá ser formado com contribuições em dinheiro ou em qualquer espécie de bens suscetíveis de avaliação em dinheiro. (...) $§ 5^{\circ}$ Aplica-se à assembléia referida neste artigo o disposto nos $\S \S 1^{\circ}$ e $2^{\circ}$ do artigo 115 ;

Art. 122. Compete privativamente à assembléia-geral: (...) VI - deliberar sobre a avaliação de bens com que o acionista concorrer para a formação do capital social;

59 Art. 122. Compete privativamente à assembléia-geral: (...) III - tomar, anualmente, as contas dos administradores e deliberar sobre as demonstrações financeiras por eles apresentadas;

60 Art. 152. A assembléia-geral fixará o montante global ou individual da remuneração dos administradores, inclusive benefícios de qualquer natureza e verbas de representação, tendo em conta suas responsabilidades, o tempo dedicado às suas funções, sua competência e reputação profissional e o valor dos seus serviços no mercado.

${ }^{61}$ Nesse sentido, CARVALHOSA, Modesto de Souza Barros. Comentários à Lei das Sociedades Anônimas. $3^{a}$ ed. São Paulo: Saraiva, 2003. v. II, p. 463; REGO, Marcelo Lamy. Direito das Companhias. $1^{a}$ ed. Rio de Janeiro: Forense. v. I, p. 411; FRANÇA, Erasmo Valladão Azevedo e Novaes. Conflito de Interesses nas Assembléias de S.A.. ed. única São Paulo: Malheiros, 1993. p. 87; EIZIRIK, Nelson. Temas de Direito Societário. $1^{a}$ ed. Rio de Janeiro: Renovar, 2005. p. 97; BORBA, José Eduardo Tavares. Direito Societário. $9^{\mathrm{a}}$ ed. Rio de Janeiro: Renovar. p. 329 e 330; MARTINS, Fran. Comentários à Lei das Sociedades Anônimas. $2^{\mathrm{a}}$ edição. Rio de Janeiro: Forense, 1984. p. 80 84; e Luiz Antonio Sampaio Campos, que, face ao julgamento do Inquérito Administrativo CVM N ${ }^{\circ}$ TA/RJ2001/4977 disse: "O busílis está, então, em saber se as disposições do artigo 115, § 1º da Lei no 6.404/76 requerem a abstenção do voto do acionista em qualquer hipótese ou não. A doutrina é unânime no que toca às duas primeiras hipóteses, notadamente aquelas que tratam do laudo de avaliação e da aprovação de contas por administradores. Já no que toca às duas hipóteses seguintes, apesar haver algumas poucas manifestações em sentido oposto, pode-se dizer que há uma folgada predominância do entendimento de que não se cuida de impedimento a priori, ou presuntivo, como se observará abaixo." 
seus próprios atos. ${ }^{62}$ Princípio esse, vale dizer, está inserido em nosso ordenamento societário desde 1882, quando da promulgação da Lei 3.150, como visto anteriormente. A controvérsia se insere no trato da segunda metade da norma, ou seja, nas hipóteses de benefício particular e conflito de interesses. Ambas serão tratadas, mas o enfoque será na última hipótese. $\mathrm{O}$ benefício particular será abordado em tópico separado.

Foi por meio da redação do parágrafo $1^{\circ}$ do artigo 115 da lei societária que se importou ao Brasil a polêmica de como interpretar o termo conflito de interesses. Debate que começou há tempos no continente europeu e chamou a atenção, inclusive, dos juristas da Itália, de cuja lei serviu de inspiração ao legislador pátrio para posterior a edição da Lei das S.A..

O Congresso Nacional poderia ter evitado tal controvérsia ao explicitar como deveria ser feita a verificação da situação conflituosa. ${ }^{63}$ Preferiu, no entanto, deixar a redação da forma mais genérica e abrangente, dando espaço à doutrina e à magistratura para formarem seu próprio entendimento. É o que se pode concluir por meio da leitura da exposição de motivos da Lei das S.A., $\mathrm{n}^{\circ}$ 196, de 24 de junho de 1976:

"O artigo 115 cuida dos problemas do abuso do direito de voto e do conflito de interesses entre o acionista e a companhia. Trata-se de matéria delicada em que a lei deverá deter-se em alguns padrões necessariamente genéricos, deixando à prática e à jurisprudência margem para a defesa do minoritário sem inibir o legítimo exercício do poder de maioria, no interesse da companhia e da empresa." 64

\footnotetext{
${ }^{62}$ REGO, Marcelo Lamy. Direito das Companhias. $1^{\text {a }}$ ed. Rio de Janeiro: Forense. v. I, p. 412.

${ }^{63}$ CAMPOS, Luiz Antonio Sampaio. Direito das Companhias. $1^{\mathrm{a}}$ ed. Rio de Janeiro: Forense, 2009. v. I, p. 1155: "A Lei no 6.404/1976 não define o que seria conflito de interesses, embora no seu corpo se encontrem indicações do tratamento adequado para a questão (v. arts. 245 e 264 e os próprios $\S \S 1^{\circ} \mathrm{e}$ $2^{\circ}$ do art. 156)."

${ }^{64}$ Disponível no site da CVM <http://www.cvm.gov.br/port/atos/leis/6404_Exposicao.asp>. Acesso em 10 de maio de 2011.
} 
Foi nesse cenário, portanto, que se acirraram as discussões sobre a interpretação do termo conflito de interesses, com destaque para o embate entre as correntes formalista e materialista, tratadas no capítulo seguinte. 


\section{CAPÍTULO 3 \\ CORRENTES FORMAL E MATERIAL}

\subsection{Correntes Formal e Material}

Desde a promulgação da Lei das S.A., em 1976, até os dias de hoje, persiste entre os juristas a controvérsia sobre a forma de se identificar uma situação conflituosa. Diversos doutrinadores, aqui e alhures, já se dedicaram ao estudo dessa matéria. Dividem-se eles, basicamente, em dois grupos: a corrente formal e a material ou substancial.

Grosso modo, os primeiros entendem que o parágrafo $1^{\circ}$ do artigo 115 da Lei das S.A. trata somente da forma de conflito lato sensu, caracterizado, como o nome já diz, por questões formais ou de aparência. Já os segundos vêem o conflito stricto sensu, como uma situação identificada apenas por fundamentos materiais.

O conflito formal de interesses, como definido por Nelson Eizirik, é aquele que existe em todo negócio jurídico em que o acionista e a sociedade são as partes contratantes. ${ }^{65}$ Os formalistas entendem que o conflito de interesses se caracterizaria assim, somente pela aparência do negócio, dispensando qualquer análise concernente ao conteúdo da decisão. ${ }^{66}$

\footnotetext{
${ }^{65}$ EIZIRIK, Nelson. Temas de Direito Societário. $1^{\mathrm{a}}$ ed. Rio de Janeiro: Renovar, 2005. p. 72.

${ }^{66}$ FRANÇA, Erasmo Valladão Azevedo e Novaes. Conflito de Interesses nas Assembléias de S.A.. ed. única São Paulo: Malheiros, 1993. p. 96: “(...) Ora, a hipótese de um contrato entre o acionista e a companhia é considerada a hipótese paradigmática de conflito formal de interesses, ipotesi di scuola, como diz Galgano (...)."
} 
Parte-se do princípio que o acionista não pode participar da formação da vontade de ambas as partes sob o risco de privilegiar seu interesse particular em face do interesse da companhia. Estendem, por isso, preventivamente, o impedimento de voto aplicável às duas primeiras hipóteses do parágrafo $1^{\circ}$ do artigo 115 (laudo de avaliação e aprovação das contas como administrador) às situações de conflito de interesse.

A corrente formalista de interesses tem entre seus seguidores especialmente os juristas mais inclinados às teorias institucionalistas, já que encaram o direito de voto como um poder exercido no interesse alheio, no caso, o da sociedade. ${ }^{67}$ Dentre os mais ilustres seguidores da tese formal em nosso país, está Modesto de Souza Barros Carvalhosa:

"A configuração do interesse conflitante, além das duas hipóteses tipificadas em lei, torna-se uma questão que a priori somente pode ser deslindada através do critério formal. Impossível encarar a questão casuisticamente. (...) o contraste de interesses das partes, que existe em todo contrato bilateral ou unilateral, é a razão formal para a suspensão do exercício do voto pelo acionista pré-contratante ou contratante com a sociedade." 68

Dentre os juristas estrangeiros pode-se mencionar Rodrigo Uría, citado pela ex-diretora da CVM Norma Jonssen Parente, face ao Inquérito Administrativo CVM No TA-RJ2002/1153:

"En la emisión del voto goza el accionista de amplia libertad. Puede votar en el sentido que tenga por conveniente, sin otros límites que el respeto al interés de la sociedad, la moral y el orden público. Ahora bien, el interés de la sociedad correrá grave peligro siempre que el accionista tenga un interés propio y particular en el asunto sometido a la decisión de la junta, porque entonces el accionista puede sentirse inclinado a supeditar la conveniencia de la sociedad a su propio interés

${ }^{67}$ CARVAlHOSA, Modesto de Souza Barros. Comentários à Lei das Sociedades Anônimas. $3^{\mathrm{a}}$ ed. São Paulo: Saraiva, 2003. v. II, p. 451 e 452: "Essa concepção de direito de voto como poder exercido no interesse alheio - no caso, o da sociedade - acarreta inquestionavelmente o dever de abster-se do voto, no caso de conflito formal de interesses com a sociedade."

${ }^{68}$ CARVAlHOSA, Modesto de Souza Barros. Comentários à Lei das Sociedades Anônimas. $3^{\mathrm{a}}$ ed. São Paulo: Saraiva, 2003. v. II, p. 464. 
personal. De ahí que, en el supuesto de conflicto o colisión de intereses entre la sociedad y el socio, éste deba abstenerse de emitir el voto en el asunto u operación concreta en que se dé la colisión; si, no obstante, el voto se emitiera y fuera decisivo para la fomación de la mayoría, el acuerdo social podría ser impugnado al amparo del artículo 115, siempre que con la emisión de ese voto se haya causado lesión a los intereses de la sociedad; ese precepto puede implicar, en definitiva, la necesidad de posponer el interés personal del accionista al interés social, cuando uno y outro entren em conflicto y con ello se lesione realmente el interés social." ${ }^{69}$

Em contraponto à teoria formal, como dito acima, está a tese material do conflito de interesses, apoiada pela maioria da doutrina ${ }^{70}$. O conflito substancial de interesses, ou conflito stricto sensu, de acordo com Nelson Eizirik ocorre quando o poder de voto é utilizado com desvio de finalidade, para promover interesses incompatíveis do acionista com o interesse social. ${ }^{71}$ Os materialistas apóiam-se nessa leitura de conflito. A consequência lógica disso é que passa-se a exigir, para tal enquadramento, provas materiais dessa incompatibilidade, o que requer, por sua vez, que se faça uma análise caso a caso, necessariamente a posteriori da tomada da deliberação.

Dessa forma, os adeptos à corrente substancial restringem a aplicação do impedimento de voto previsto no parágrafo $1^{\circ}$ do artigo 115 da Lei das S.A. apenas aos casos onde, necessariamente, sabe-se de antemão que o conflito irá trazer prejuízos para a companhia ou os demais acionistas.

\footnotetext{
${ }^{69}$ URÍA, Rodrigo; Derecho Mercantil. Madrid: Marcial Pons, Ediciones Jurídicas S.A. 1995. p. 308. Citado por Norma Jonssen Parente face ao julgamento do Inquérito Administrativo CVM n ${ }^{\circ} \mathrm{RJ}$ 2002/1153. Disponível no site da $\quad$ CVM <http://www.cvm.gov.br/port/inqueritos/2002/rordinario/inqueritos/TARJ2002_1153.asp>. Acesso em 10 de maio de 2011.

${ }^{70}$ EIZIRIK, Nelson. Temas de Direito Societário. $1^{\text {a }}$ ed. Rio de Janeiro: Renovar, 2005. p. 97: "Com efeito, na hipótese de conflito de interesses (art. $115, \S \S 1^{\circ}$ e $4^{\circ}$ da Lei das S.A.) o entendimento dominante com base no direito comparado, é de que a lei não está se reportando a um conflito meramente formal, mas a um conflito substancial, que somente pode ser verificado mediante exame do conteúdo da deliberação."

CAMPOS, Luiz Antonio Sampaio. Direito das Companhias. $1^{\text {a }}$ ed. Rio de Janeiro: Forense, 2009. v. I, p. 1156: "Embora haja alguma controvérsia sobre a extensão que se deva dar ao conteúdo da expressão conflito de interesses, a doutrina, de uma forma geral, tem se inclinado para estabelecer que o conflito de interesses é matéria de fato, que deve ser examinada em cada caso concreto, não sendo mesmo improvável que para situações teoricamente iguais ocorram, do ponto de vista da configuração do conflito de interesses, soluções diferentes."

${ }^{71}$ EIZIRIK, Nelson. Temas de Direito Societário. $1^{\mathrm{a}}$ ed. Rio de Janeiro: Renovar, 2005. p. 72.
} 
Os adeptos à corrente material defendem seu entendimento, sobretudo, com base no Direito Comparado e nos Princípios da Boa-Fé e do Princípio Majoritário. Veja-se abaixo, nesse sentido, as palavras de Marcelo Lamy Rego, Nelson Eizirik e Luiz Antonio Sampaio Campos, alguns dos mais veementes defensores de tal tese:

\begin{abstract}
"A interpretação correta dos dispositivos da LSA é a de que o conflito de interesses não pode ser determinado a priori, a não ser nas hipóteses de conflito formal, semelhantes ao que a doutrina italiana chama de divieto de voto. (...) Nesses casos, a lei prevê o conflito impeditivo do voto (...) como remédio preventivo, proíbe o voto independentemente do exame de mérito. (...) A própria natureza do conflito de interesses não comporta interpretação literal desse dispositivo da LSA. (...) Por não se poder prever, de antemão, o comportamento do acionista, é que o conflito de interesses deve ser analisado caso a caso." ${ }^{, 72}$
\end{abstract}

“Ademais, seguindo a orientação consagrada no direito societário, tanto em nosso sistema jurídico como no direito comparado, a caracterização do conflito de interesses não é meramente formal, mas substancial, devendo, portanto, ser objeto de apreciação na hipótese concreta." ${ }^{, 73}$

"Já a hipótese de interesse conflitante com a companhia deve ser objeto de apreciação caso a caso, inexistindo a proibição absoluta do direito de voto" 74 ;

"Embora haja alguma controvérsia sobre a extensão que se deva dar ao conteúdo da expressão conflito de interesses, a doutrina, de uma forma geral, tem se inclinado para estabelecer que o conflito de interesse é matéria de fato, que deve ser examinada em cada caso concreto, não sendo mesmo improvável que para situações teoricamente iguais ocorram, do ponto de vista da configuração do conflito de interesses, soluções diferentes. (...) A eventual duplicidade de interesses não é caracterizadora de conflito de interesses. A relação bilateral não induz conflito de interesses necessariamente." $" 75$

Outro adepto à tese material é Fran Martins: “(...) Difícil é, às vezes, descobrir quando os interesses da companhia conflitam com os dos acionistas,

\footnotetext{
${ }^{72}$ REGO, Marcelo Lamy. Direito das Companhias. $1^{\text {a }}$ ed. Rio de Janeiro: Forense. v. I, p. 422 a 424.

${ }^{73}$ EIZIRIK, Nelson. Temas de Direito Societário. $1^{\text {a }}$ ed. Rio de Janeiro: Renovar, 2005. p. 48 e 49.

${ }^{74}$ EIZIRIK, Nelson. Temas de Direito Societário. $1^{\text {a }}$ ed. Rio de Janeiro: Renovar, 2005. p. 97.

${ }^{75}$ CAMPOS, Luiz Antonio Sampaio. Direito das Companhias. $1^{\text {a }}$ ed. Rio de Janeiro: Forense, 2009. v. I, p. 1156 e 1157.
} 
por se tratar de matéria de fato" ${ }^{, 76}$. Ainda, no mesmo sentido, Luiz Gastão Paes de Barros Leães: "Inicialmente, cumpre advertir que a configuração dos interesses conflitantes é de natureza substancial, e não meramente formal, como a significar a posição das partes contratantes, que de resto existe em todo contrato bilateral ou sinalagmático.,"77

Por último, cabe salientar que essa concepção materialista do conflito de interesses é privilegiada, sobretudo, pela posição contratualista de interesse social, como muito bem explicado por Fabio Konder Comparato e Calixto Salomão Filho. ${ }^{78}$

\subsection{O Conflito}

O primeiro ponto de atrito entre as duas teorias começa na própria definição do vocábulo conflito, que tem suas origens no léxico latino conflictu. Vejamos abaixo algumas das definições extraídas de diversas fontes, imprescindíveis para a delimitação do alcance da norma constante do parágrafo $1^{\circ}$ do artigo 115 da Lei das S.A.:

“conflito [Do lat. conflictu, 'choque', 'embate', 'peleja', do lat. confligere, 'lutar'.] S. m. 1. Embate dos que lutam. 2. Discussão acompanhada de injúrias e ameaças; desavença. 3. Guerra (1). 4. Luta, combate. 5. Colisão, choque: As opiniões dos dois entram sempre em conflito. (...)" (grifou-se) ${ }^{79}$

\footnotetext{
${ }^{76}$ MARTINS, Fran. Comentários à Lei das Sociedades Anônimas. $2^{\mathrm{a}}$ edição. Rio de Janeiro: Forense, 1984. p. 84.

${ }^{77}$ LEÃES, Luiz Gastão Paes de Barros. Estudos e Pareceres sobre Sociedades Anônimas. São Paulo: Revista dos Tribunais, 1989. p. 32.

${ }^{78}$ COMPARATO, Fabio Konder; SALOMÃO FILHO, Calixto. O Poder de Controle na Sociedade Anônima. $4^{\mathrm{a}}$ ed. Rio de Janeiro: Forense. 2005. p.389: "A posição contratualista tradicional privilegia a chamada regra de conflito de interesses material. Segundo ela o voto do acionista em assembléia é sempre permitido, devendo ser a posteriori comparado ao interesse social para eventual anulação."

${ }^{79}$ Aurélio Buarque de Holanda Ferreira.
} 
"Conflito (...) 1 profunda falta de entendimento entre duas ou mais partes (...) 2 p.ext. choque, enfrentamento (...) 4 p.ana. ato, estado ou efeito de divergirem acentuadamente ou se oporem duas ou mais coisas (...) c. de direitos jur convergência de direitos antagônicos de dois ou mais indivíduos, que obriga a que nenhum deles tenha exercício pleno ou exerça gozo exclusivo do direito do qual se arroga titular: colisão de direitos (...)" (grifou-se) ${ }^{80}$

"conflict, in psychology, the arousal of two or more strong motives that cannot be solved together." (grifou-se) ${ }^{81}$

De acordo com os extratos acima, poder-se-ia entender que conflito de interesses seria o choque intransponível de dois ou mais interesses que os impede de terem seu exercício pleno. Os defensores da corrente formalista definem, contudo, o vocábulo de forma diversa. Para Norma Jonssen Parente, ex-diretora da CVM, "Não é verdade que o acionista só deve se abster de votar quando o seu interesse particular implicar no sacrifício do interesse da sociedade" e, ainda, "o conflito de interesses não exige que os interesses sejam opostos, mas que o acionista tenha duplo interesse" ${ }^{82}$ É dessa forma que os formalistas buscam enquadrar a hipótese clássica de contratação entre acionista e companhia em situação conflituosa. Modesto de Souza Barros Carvalhosa manifesta-se na mesma direção:

“(...) o contraste de interesses das partes, que existe em todo o contrato bilateral ou unilateral, é a razão formal para a suspensão do exercício do voto pelo acionista précontratante com a sociedade. (...) Mesmo quando existam benefícios equitativos para ambas as partes, que é aquilo que se deve pressupor, haverá sempre conflito e não convergência de interesses." ${ }^{, 3}$

Os defensores da corrente materialista rebatem fortemente o argumento formalista, apoiados na interpretação literal do vocábulo conflito, que,

\footnotetext{
${ }^{80}$ Antônio Houaiss.

${ }^{81}$ The New Encyclopadia Britannica, ed. 15. 1986., vol. 3, p. 529.

${ }^{82}$ Voto de Norma Jonssen Parente em face do julgamento do Inquérito Administrativo CVM N ${ }^{\circ}$ TA/RJ2001/4977. Disponível no site da $\quad$ CVM <http://www.cvm.gov.br/port/inqueritos/2001/rordinario/inqueritos/4977.asp>. Acesso em 10 de maio de 2011.

${ }^{83}$ CARVAlhoSA, Modesto de Souza Barros. Comentários à Lei das Sociedades Anônimas. $3^{\mathrm{a}}$ ed. São Paulo: Saraiva, 2003. v. II, p. 464.
} 
conforme visto acima, seria um choque intransponível entre dois ou mais interesses distintos na mesma pessoa, sem a possibilidade de convergência ou conciliação entre esses interesses. ${ }^{84}$

Nesse sentido, manifesta-se Fabio Ulhoa Coelho, "conflitante é o voto manifestado em matéria acerca da qual o acionista votante tem interesse inconciliável com o da sociedade". ${ }^{85}$ (grifou-se) E, além dele, Luiz Antonio Sampaio Campos, ao afirmar que "A eventual duplicidade de interesses não é caracterizadora de conflito de interesses. A relação bilateral não induz conflito de interesses necessariamente". ${ }^{86}$

Ocorre que, se existe a possibilidade de o acionista votar em favor do interesse social, estaria ele, conciliando os dois interesses: o seu particular e o da companhia. $\mathrm{O}$ contrato entre essas duas partes pode sim beneficiar ambas simultaneamente, desde que celebrados em condições equitativas, observandose as boas práticas do mercado e, além disso, nas mesmas condições que seriam contratadas com terceiros.

Concentra-se justamente aí um dos argumentos dos materialistas, que defendem que, para tal configuração de conflito intransponível, deve haver, necessariamente, uma análise profunda baseada em provas substanciais e exigindo, por sua vez, um estudo caso a caso das hipóteses conflituosas. Defendem eles que a situação conflituosa estaria restrita apenas às hipóteses em que o acionista, necessariamente, vá sacrificar o interesse social frente a

\footnotetext{
${ }^{84}$ REGO, Marcelo Lamy. Direito das Companhias. $1^{\text {a }}$ ed. Rio de Janeiro: Forense. v. I, p. 420: "O conflito de interesses existe quando o interesse particular do sócio e o interesse social, este entendido como o interesse comum dos sócios, estão em situação contraposta ou antagônica"

${ }^{85}$ COELHO, Fábio Ulhoa. Curso de Direito Comercial. $8^{\text {a }}$ ed. São Paulo: Saraiva. v. II, p. 313

${ }^{86}$ CAMPOS, Luiz Antonio Sampaio. Direito das Companhias. $1^{a}$ ed. Rio de Janeiro: Forense. v. I, p. 1157.
} 
seu interesse particular. Marcelo Lamy Rego segue esse entendimento ao afirmar que:

"A expressão 'contraposta ou antagônica' é usada porque, caso exista a possibilidade de coexistência não danosa entre os dois interesses díspares, não há que se falar em conflito. $\mathrm{O}$ interesse pode ser complementar, não excludente. $\mathrm{O}$ conflito nasce no momento em que os interesses são mutuamente excludentes (ainda que em parte), em que um necessariamente prejudica o outro, e em que o acionista se volta para fora do círculo societário, no qual está intimamente ligado a seus pares e aos destinos do empreendimento comum, para decidir o conteúdo do seu voto. Exerce, pois, seu direito de voto para satisfazer a esse interesse externo, estranho." ${ }^{87}$

Nelson Eizirik segue o mesmo entendimento, ao afirmar que configurase o conflito de interesse porque a satisfação do interesse meramente individual somente poderá ocorrer mediante o sacrifício do interesse coletivo e viceversa, essa situação, por sua vez, somente poderia ser verificada por elementos fáticos. ${ }^{88}$

Na mesma linha, Francesco Galgano, conforme citação do ex-diretor da CVM Luiz Antonio de Sampaio Campos em seu voto no Processo Administrativo Sancionador TA/RJ2001/4977 (Caso TIM):

\begin{abstract}
"Hay conflicto de intereses entre socio y sociedad cuando el socio se encuentra en la condición de ser titular, ante determinada decisión, de un doble interés: de su interés de socio y, además, de un interés externo de la sociedad, y esta duplicidad de intereses ha de ser de tal naturaleza que no pueda obtener el uno sin sacrificar el otro interés. (...) La simple duplicidad de la posición de intereses en cabeza de un mismo sujeto por sí sola no implica, sin embargo, una situación de conflicto en sentido técnico. Las dos posiciones pueden ser entre sí solidarias, ya que el socio puede alcanzar su propio interés sin perjudicar el interés de la sociedad. Inclusive, en el contrato consigo mismo el comportamiento del representante no es posible censurarlo, cuando 'el contenido del contrato esté determinada en forma que excluya la posibilidad de conflicto de intereses'.",
\end{abstract}

\footnotetext{
${ }^{87}$ REGO, Marcelo Lamy. Direito das Companhias. $1^{\text {a }}$ ed. Rio de Janeiro: Forense. v. I, p. 422

${ }^{88}$ EIZIRIK, Nelson. Temas de Direito Societário. $1^{\text {a }}$ ed. Rio de Janeiro: Renovar, 2005. p. 96 e 97.

${ }^{89}$ GALGANO, Francesco. Derecho Comercial. v. II, p. 410: citado pelo diretor Luiz Antonio em seu voto no Processo Administrativo Sancionador TA/RJ2001/4977. Disponível no site CVM <http://www.cvm.gov.br/port/inqueritos/2001/rordinario/inqueritos/4977.asp>. Acesso em 10 de maio de 2011.
} 


\begin{abstract}
Veja-se, ainda, as palavras de Carlos Fulgêncio da Cunha Peixoto, também citado por Luiz Antônio em face do julgamento do Processo Administrativo TA-RJ2002/1153 (Caso Previ):
\end{abstract}

"Não é fácil a tarefa de aferir os interesses da sociedade e os do acionista para saber
se existe ou não choque. A matéria é de fato e deve ser examinada em cada caso,
pois, mesmo em uma operação de compra e venda, em determinadas condições, não
se poderá dizer, de antemão, se haverá antagonismo entre as partes. Pode, como
proclama Eduardo de Carvalho, 'dar-se a hipótese de haver convergência ou
mutualidade de interesses, por beneficiar a ambas as partes a transação
incriminada'." (grifou-se)

E, por fim, para ilustrar esse argumento materialista, vejamos o que tem a dizer Alfredo Lamy Filho e José Luiz Bulhões Pedreira, autores do anteprojeto da Lei das S.A.:

\begin{abstract}
"Interesse conflitante significa interesse oposto, contrário, incompatível ou colidente. Não é apenas interesse diferente, ou distinto, que pode ser, inclusive, coincidente com o da companhia, ou complementar a este: é válido o voto proferido pelo acionista no interesse da companhia, ainda que na deliberação tenha outro interesse próprio, distinto do da companhia, desde que não seja com este conflitante." 91
\end{abstract}

\title{
3.3. Conflito de Interesses $x$ Proibição de Voto
}

A teoria materialista encontra no Direito Comparado outro de seus principais argumentos. Ocorre que no continente europeu existe a diferenciação entre os institutos jurídicos da proibição de voto e do conflito de

\footnotetext{
${ }^{90}$ Sociedades por Ações, Vol. 3, Carlos Fulgêncio da Cunha Peixoto, p. 81 - Citado por Luiz Antonio de Sampaio Campos face ao julgamento do Inquérito Administrativo CVM No TA-RJ2002/1153. $\begin{array}{lllll}\text { Disponível no } & \text { nite } & \text { CVM }\end{array}$ <http://www.cvm.gov.br/port/inqueritos/2002/rordinario/inqueritos/TARJ2002_1153.asp>. Acesso em 10 de maio de 2011.

${ }^{91}$ Citado pelo diretor da CVM Luiz Antônio em face do julgamento do Processo Administrativo TARJ2002/1153. Disponível no site da CVM <http://www.cvm.gov.br/port/inqueritos/2002/rordinario/inqueritos/TARJ2002_1153.asp>. Acesso em 10 de maio de 2011.
} 
interesses. Essa distinção surgiu primeiramente na Alemanha e, posteriormente, na Itália, país cuja legislação, vale lembrar, serviu de inspiração para a edição da Lei das S.A.

No antigo Código Comercial Alemão (Handelsgesetzbuch - "HGB"), datado de 1896, vedava-se o voto do acionista em quatro diferentes situações: (i) exoneração de responsabilidade perante a companhia; (ii) liberação de obrigação para com a sociedade; (iii) conclusão de negócio com a própria empresa; e (iv) propositura de ação por parte da companhia contra o acionista. O HGB, nesses casos, admitia uma presunção de conflito de interesses entre acionista e sociedade. Caso o voto fosse proferido, seria nulo de pleno direito. Erasmo Valladão Azevedo e Novaes França, que estudou a fundo essa matéria, cita Françoise Herzfelder para afirmar que:

“(...) de um lado o sistema se mostrou muito estreito à vista dos numerosos casos de conflito substanciais de interesses que não eram apanhados pela norma; de outro lado, mostrou-se muito rigoroso diante de algumas daquelas hipóteses, como, por exemplo, no caso da conclusão de negócios entre o acionista e a companhia." ${ }^{92}$

Em face disso, ao elaborar a lei acionária de 1937 (Aktiengeszetz), o legislador alemão criou um duplo regime. No §114, 5, continuava a proibir preventivamente o exercício do voto com base no preenchimento de critérios objetivos, ou formais. As hipóteses eram as mesmas dos itens (i), (ii) e (iv), citados acima. Deixou-se de incluir, contudo, a celebração de negócio entre acionista e a companhia, por se entender que aquela hipótese inibia drasticamente o voto, dando à minoria poder decisório excessivo. ${ }^{93}$ Já no $§ 197$,

\footnotetext{
${ }^{92}$ FRANÇA, Erasmo Valladão Azevedo e Novaes. Conflito de Interesses nas Assembléias de S.A.. ed. única São Paulo: Malheiros, 1993. p. 75.

${ }^{93}$ FRANÇA, Erasmo Valladão Azevedo e Novaes. Conflito de Interesses nas Assembléias de S.A.. ed. única São Paulo: Malheiros, 1993. p. 76. Nota 164: "Sobre a eliminação da hipótese referida no texto, que constituía a fattispecie mais importante do $§ 252$ do $H G B$, a qual, de resto, já era interpretada de maneira fortemente restritiva, Gambino, citando Zollner, informa que a razão de sua eliminação foi o
} 
2, determinava-se a possibilidade de anulação da deliberação decorrente de voto exercido com o objetivo de obter vantagem particular, para si ou para outrem, ou que pudesse resultar em prejuízo para a companhia ou os demais acionistas. ${ }^{94}$ Ou seja, situações em que se provasse materialmente que o acionista estava conflitado. ${ }^{95}$

Esse sistema dualista foi mantido pela lei acionária alemã de 1965, ainda em vigor. $\mathrm{O} \S 136,1$ estabelece a proibição de voto do acionista administrador em deliberações sobre a aprovação de suas próprias contas, a exoneração de obrigações para com a sociedade, ou o exercício de direitos que esta tenha em relação ao mesmo. Já as situações de conflito de interesses são listadas, por sua vez, no $§ 243,2$, que permite a anulação de deliberação em que o acionista tentar obter, pelo exercício do seu voto, para si ou para terceiros, vantagens particulares em detrimento da sociedade ou de outros acionistas, e a decisão é idônea a servir a esse escopo. ${ }^{96}$ Nas palavras de Erasmo Valladão Azevedo e Novaes França:

fato de que aquela hipótese, com inibir drasticamente o voto, terminava por atribuir à minoria excessivo poder decisório, impedindo a conclusão de contratos úteis à sociedade."

${ }^{94}$ FRANÇA, Erasmo Valladão Azevedo e Novaes. Conflito de Interesses nas Assembléias de S.A.. ed. única São Paulo: Malheiros, 1993. p. 76.

${ }^{95} \mathrm{O}$ sistema alemão é muito bem explicado nas palavras de Françoise Hensfelder, conforme citação de Luiz Antonio Sampaio Campos face ao julgamento do Inquérito Administrativo CVM No TARJ2002/1153: "Comme nous l'avons vu, les règles du droit allemand interdisant l'exercice du droit de vote, dans certains cas de conflits d'intérêts présomptifs, soulèvent de nombreux problèmes fort complexes. Ce sont des règles rigides et longtemps avant la mise en vigueur de la loi allemande de 1937 on a constaté que, d'une part, elles sont trop étroites dans de nombreux cas de conflits d'intérêts effectifs et, d'autre part, il y a certaines catégories de faits (par exemple des actes juridiques à effectuer vis-à-vis d'un actionnaire) où l'application de ces règles ne paraît possible que sous des conditions tout à fait particulières. Aussi longtemps avant 1937, la doctrine allemande a-t-elle été à la recherche d'une "clause générale ", c'est-à-dire d'une règle plus souple et mieux adaptée aux faits pour la protection de la société contre les dangers d'un vote abusif de ses propres actionnaires." La protection de la societé anonyme contre des abus de vote em cas de conflits d'intérêts em droit allemand. (Revue Trimestrielle de Droit Commercial, Tome XXI, 1968, p. 285). Disponível no site da CVM <http://www.cvm.gov.br/port/inqueritos/2002/rordinario/inqueritos/TARJ2002_1153.asp>. Acesso em 10 de maio de 2011.

${ }^{96}$ FRANÇA, Erasmo Valladão Azevedo e Novaes. Conflito de Interesses nas Assembléias de S.A.. ed. única São Paulo: Malheiros, 1993. p. 76 a 81. 
“(...) nas hipóteses de proibição de voto, a lei alemã, com base em precisas circunstâncias formais, estabelece um controle ex ante de legitimidade do voto; violada a proibição, decorre a consequentia juris da nulidade do voto e da anulabilidade da deliberação, se o voto for decisivo para a formação da maioria. Já no que tange ao conflito de interesses, há um controle ex post: torna-se necessária uma indagação relativamente ao mérito da deliberação, para a qual foi decisivo o voto do acionista, a fim de se apurar se efetivamente ocorreu incompatibilidade entre os seus interesses e o interesse da companhia" $" 97$

As normas de direito sobre os conflitos de interesse evoluíram de forma semelhante na Itália. O antigo Codice di Commercio, datado de 1882, em seu artigo 161, estabelecia a proibição de voto, ou divieto di voto , como ficou conhecido, "nas deliberações assembleares de aprovação de balanço e naquelas que dissessem respeito à sua própria responsabilidade perante a companhia". Já o artigo 150 da mesma lei, determinava a abstenção de administrador que, em determinada operação, estivesse em conflitto di interessi com a sociedade, sob pena de responder pelos prejuízos causados. ${ }^{98}$

Segundo Agostino Gambino, citado por Erasmo Valladão Azevedo e Novaes França, a jurisprudência e a doutrina majoritária italianas admitiam, à semelhança do direito alemão, uma diferenciação na aplicação das duas normas. A hipótese de divieto di voto do artigo 161 acarretaria na nulidade do voto, caso fosse proferido, diferentemente de conflitto di interessi do artigo 150 , que provocaria apenas a responsabilidade do administrador por perdas e danos. $^{99}$

Na edição do Codice Civile Italiano, de 1942, que revogou o Codice di Commercio, se utilizou novamente o regime duplo de conflitto di interessi e divieto di voto. Tratou-se tal matéria no artigo 2.373 a seguir transcrito:

\footnotetext{
${ }^{97}$ FRANÇA, Erasmo Valladão Azevedo e Novaes. Conflito de Interesses nas Assembléias de S.A.. ed. única São Paulo: Malheiros, 1993. p. 77 e 78.

${ }^{98}$ FRANÇA, Erasmo Valladão Azevedo e Novaes. Conflito de Interesses nas Assembléias de S.A.. ed. única São Paulo: Malheiros, 1993. p. 78.

${ }^{99}$ FRANÇA, Erasmo Valladão Azevedo e Novaes. Conflito de Interesses nas Assembléias de S.A.. ed. única São Paulo: Malheiros, 1993. p. 78.
} 
"Art. 2373 Conflitto d'interessi. Il diritto di voto non può essere esercitato dal socio nelle deliberazioni in cui egli ha, per conto proprio o di terzi, un interesse in conflitto con quello della società.

In caso d'inosservanza della disposizione del comma precedente, la deliberazione, qualora possa recare danno alla società, è impugnabile a norma dell'art. 2377 se, senza il voto dei soci che avrebbero dovuto astenersi dalla votazione, non si sarebbe raggiunta la necessaria maggioranza.

Gli amministratori non possono votare nelle deliberazioni riguardanti la loro responsabilità (2393)" 100

No caso do divieto di voto, abordado pelo $3^{\circ}$ parágrafo do artigo transcrito acima, o legislador, baseado em precisas circunstâncias taxativas e formais, interdita o exercício do voto, determinando a nulidade do voto proferido em desobediência à norma e a anulabilidade da deliberação em que esse voto tenha sido fundamental para a formação da maioria necessária para sua aprovação. Já a primeira parte do artigo ultramencionado, como se pode ver, trata do conflitto di interessi. Nesse caso, a anulabilidade somente ocorrerá se, verificado o mérito da deliberação, ela for suscetível de causar dano, potencial ou efetivo, à sociedade.

Foi essa a fórmula que os legisladores alemão e italiano encontraram para conciliar, de um lado, a proteção dos interesses sociais e minoritários, e, de outro, o Princípio Majoritário e o interesse legítimo do controlador. Dividiuse a aplicação de remédios conforme a espécie de conflito: formal ou material. Com o objetivo de evitar uma afronta aos direitos dos acionistas controladores, restringiu-se as hipóteses de proibição de voto às circunstâncias onde o conflito de interesses era totalmente aparente. Presumiu-se, neste caso, que o acionista estava conflitado mesmo antes de tomada a deliberação, e, consequentemente,

\footnotetext{
100 Disponível no site The Cardozo Electronic Law Bulletin <http://www.jus.unitn.it/cardozo/obiter_dictum/codciv/codciv.htm>. Acesso em 10 de maio de 2011.
} 
interditou-se seu direito de voto com base no preenchimento de quesitos meramente objetivos.

Ao mesmo tempo, para não limitar os direitos da sociedade e dos minoritários, o legislador concedeu a possibilidade de se enquadrar as demais situações de conflito de interesses em norma genérica. Para isso, precisava provar-se apenas que, de fato, o dano havia ocorrido, imputando-se ao acionista, a responsabilidade sobre tais perdas.

Tendo esclarecido a distinção entre os conceitos de proibição de voto e conflito de interesses, tão pertinentes a esta obra, não surpreende qualquer semelhança com a redação do parágrafo $1^{\circ}$ do artigo 115 da nossa lei societária. Defendem os substancialistas, justamente, que o legislador brasileiro, ao elaborar a Lei das S.A., em 1976, conhecia e usou-se dessa classificação que constava nos ordenamentos jurídicos da Alemanha e da Itália desde 1937 e 1942, respectivamente. Vejamos o que dizem Marcelo Lamy Rego e Erasmo Valladão Azevedo e Novaes França sobre o tema:

\begin{abstract}
"As três primeiras hipóteses são hipótese às quais a lei dá tratamento semelhante ao divieto de voto, tendo o legislador prescrito situações formais em que o acionista não pode exercer o voto. (...) O conflito de interesses na lei brasileira, assim como nas doutrinas alemã e italiana, é hipótese distinta das demais, apesar de estar relacionada juntamente com as proibições objetivas de voto. (...) Entendemos que o conflito de interesses é caso em que a tutela do interesse social se dá a posteriori, com a análise do caso concreto." 101
\end{abstract}

"Antes de mais nada, soa perfeitamente claro que as duas primeiras hipóteses nele reguladas [parágrafo1 $1^{\circ}$ do artigo 115], são hipóteses de divieto de voto. Nas deliberações relativas ao laudo de avaliação de bens que conferiu ao capital social e à aprovação das suas contas como administrador, o acionista está proibido de votar (...) sendo de todo dispensável perquirir acerca da ocorrência de prejuízo para a companhia ou para os acionistas (...). Ocorreria o conflito de interesses, por sua vez,

${ }^{101}$ REGO, Marcelo Lamy. Direito das Companhias. $1^{\mathrm{a}}$ ed. Rio de Janeiro: Forense, 2009. v. I, p. 411. 
em todas as demais hipóteses em que for apurada efetiva conflituosidade, expressa em uma vantagem experimentada pelo acionista de modo particular (...)."

Como se fosse necessário, por último, transcreve-se abaixo as palavras de José Luiz Bulhões Pedreira e Alfredo Lamy Filho ao falarem sobre o poder de controle:

"Na disciplina do poder de controle a Lei não contém, todavia, normas simétricas às do artigo 115, que pró́bem o exercício do direito de voto em determinadas situações ou declaram anulável o voto proferido em situação de conflito de interesses. Essa diferença se explica porque as situações de impedimento ou conflito de interesses no exercício do direito de voto previstas no artigo 115 são esporádicas, enquanto o exercício do poder de controle é permanente, e a norma que vedasse ao acionista controlador exercer o direito de voto por conflito de interesses seria incompatível com o dever legal de exercer o controle, além de conflitar com o princípio majoritário, que é fundamental para o funcionamento eficiente da companhia. Em matéria de contratação com a companhia, que é um dos mais freqüientes - senão o mais freqüente - casos em que pode ocorrer conflito de interesses, a Lei admite implicitamente a contratação, desde que em condições de não-favorecimento ou equitativas (art. $117 \S 1^{\circ}$, 'f'). Por essas razões, as normas do artigo 115 sobre proibição de voto e conflito de interesses somente se aplicam ao exercício do direito de voto pelo acionista controlador enquanto compatíveis com as atribuições deste, o que não implica, evidentemente, que não possa ser responsabilizado se exerce o voto, em qualquer caso, com violação das normas que regulam o exercício do poder de controle." ${ }^{103}$ (grifou-se)

Não se pode, contudo, deixar de mencionar a crítica dos seguidores da tese formalista a essa classificação. Alegam que essa interpretação é falha, pois estar-se-ia admitindo a heterogeneidade dos comandos do parágrafo $1^{\circ}$ do art. 115. Veja-se abaixo o que disse, nesse sentido, a diretora Maria Helena Santana face ao Processo Administrativo $N^{\circ}$ RJ 2009-13179:

"A outra fragilidade da visão vinculada ao chamado conflito substancial diz respeito à incongruência que introduz na interpretação do disposto no $\S 1^{\circ}$ do art. 115 . Isto porque, a se adotar essa posição, seria necessário admitir a heterogeneidade do comando contido nesse preceito legal, que teria, por assim dizer, enunciado sucessivamente três hipóteses de proibição de voto - laudo de avaliação dos bens

\footnotetext{
${ }^{102}$ FRANÇA, Erasmo Valladão Azevedo e Novaes. Conflito de Interesses nas Assembléias de S.A.. ed. única São Paulo: Malheiros, 1993. p. 87

${ }^{103}$ BULHÕES PEDREIRA, José Luiz; LAMY FILHO, Alfredo. Direito das Companhias. $1^{\text {a }}$ ed. Rio de Janeiro: Forense, 2009. v. I, p. 840.
} 
com que concorrer o acionista para a formação do capital social, aprovação das contas do acionista como administrador, qualquer outra que possa beneficiar o acionista de modo particular - para, ao final, introduzir regra de natureza totalmente diversa, pela qual não mais se impediria o acionista de votar, mas, ao contrário, estaria estabelecida a sanção posterior ao voto exercido em contradição com o interesse da companhia."

\section{Modesto de Souza Barros Carvalhosa segue o mesmo entendimento:}

"Outra fragilidade de tal visão, agora suprimida pela CVM, está em uma interpretação incongruente do parágrafo $1^{\circ}$ do art. 115. Para se adotar a posição do chamado conflito substancial (ou material), seria necessário admitir a heterogeneidade do comando contido nesse preceito legal. Isto é, depois de enunciar sucessivamente três hipóteses de proibição de voto, a lei teria introduzido regra de natureza totalmente diversa: estabelecendo a sanção posterior ao voto, se exercido em contradição de interesse da companhia." 105

Entretanto, basta uma breve leitura do parágrafo $4^{\circ}$ do artigo 115 para constatarmos que o próprio legislador admitiu essa diferenciação entre o conflito de interesse e os demais casos do parágrafo $1^{\circ}$ do artigo 115 , ao cominar remédios jurídicos diversos entre essas hipóteses. Veja-se novamente a redação do parágrafo $4^{\circ}$ :

"§ $4^{\circ}$ A deliberação tomada em decorrência do voto de acionista que tem interesse conflitante com o da companhia é anulável; o acionista responderá pelos danos causados e será obrigado a transferir para a companhia as vantagens que tiver auferido."106

Como vemos pela leitura do dispositivo acima citado, a anulabilidade é aplicável somente aos casos de conflito de interesses, não aos demais casos previstos no parágrafo $1^{\circ}$ (laudo de avaliação, a aprovação das suas contas, e benefício particular), aos quais deve ser aplicada automaticamente a nulidade.

${ }^{104}$ Citação retirada do voto da diretora-presidente da CVM Maria Helena Santana face ao Processo Administrativo CVM $\mathrm{N}^{\circ}$ RJ 2009-13179. Disponível no site da CVM <http://www.cvm.gov.br/port/descol/respdecis.asp?File=7190-1.HTM>. Acesso em 10 de maio de 2011.

${ }^{105}$ CARVALHOSA. Modesto de Souza Barros. Revista Capital Aberto. ed. 89, 2010, p. 30.

${ }^{106}$ Disponível no site do Planalto <http://www.planalto.gov.br/ccivil/leis/2002/L10406.htm>. Acesso em 10 de maio de 2011. 
Para reforçar tal entendimento, veja-se o que dispõe o inciso VII do artigo 166 do Código Civil Brasileiro (Lei 10.406 de 10 de janeiro de 2002):

“Art. 166. É nulo o negócio jurídico ${ }^{107}$ quando: (...) VII - a lei taxativamente o declarar nulo, ou proibir-lhe a prática, sem cominar sanção." 108

Portanto, tendo a lei vedado o exercício do direito de voto nas três primeiras hipóteses do parágrafo $1^{\circ}$ do artigo 115 , sem cominar-lhes sanção, deduz-se que, sendo o voto proferido em desacordo, será nulo de pleno direito. Por outro lado, como a Lei das S.A. cominou sansão expressamente para o voto proferido em conflito de interesses, tal voto não é nulo, mas anulável. ${ }^{109}$

Em suma, o legislador dividiu as espécies de remédios jurídicos aplicáveis às diferentes hipóteses do parágrafo $1^{\circ}$ do artigo 115 em duas categorias: (i) nulidade para os três primeiros casos; e (ii) anulabilidade, responsabilidade por perdas e danos e transferência de vantagens para a companhia na última hipótese. ${ }^{110}$ Fez isto, justamente por saber que o voto do acionista em conflito aparente poderia ser proferido em favor dos interesses da companhia, descartando a necessidade de uma nulidade imperativa ${ }^{111}$.

${ }^{107}$ Segundo Francisco Cavalcanti Pontes de Miranda, citado por Marcelo Lamy Rego, "o voto é ato jurídico stricto sensu ou negócio jurídico. Está, portanto, sujeito às mesmas sanções de nulidade e anulabilidade dos mesmos." REGO, Marcelo Lamy. Direito das Companhias. $1^{a}$ ed. Rio de Janeiro: Forense, 2009. v. I, p. 414.

${ }^{108}$ Disponível no site do Planalto <http://www.planalto.gov.br/ccivil/leis/2002/L10406.htm>. Acesso em 10 de maio de 2011.

${ }^{109}$ REGO, Marcelo Lamy. Direito das Companhias. $1^{\text {a }}$ ed. Rio de Janeiro: Forense, 2009. v. I, p. 411 a 415.

${ }^{110}$ EIZIRIK, Nelson. Temas de Direito Societário. $1^{\text {a }}$ ed. Rio de Janeiro: Renovar, 2005. p. 330 e 331: "O voto conflitante, além de gerar responsabilidade indenizatória e obrigação de transferir à sociedade as vantagens aferidas, acarreta a anulabilidade da deliberação para a qual tenha sido dicisivo."

${ }^{111}$ Art. 169. O negócio jurídico nulo não é suscetível de confirmação, nem convalesce pelo decurso do tempo;

Art. 172. O negócio anulável pode ser confirmado pelas partes, salvo direito de terceiro. 
Por fim, cabe destacar que para que um voto possa ser anulado, requerse, necessariamente, uma análise caso a caso feita, consequentemente, ex post. Marcelo Lamy Rego segue esse entendimento:

"E a anulação do voto em conflito de interesses depende de uma análise do conteúdo do mesmo. Tendo o acionista sacrificado o interesse coletivo em prol do interesse individual, seu voto deve ser anulado. Nada obstante, tendo o acionista cumprido com a obrigação primária de votar no interesse da sociedade, seu voto é válido. É justamente por isso que não se pode prever, de antemão, o comportamento do acionista, que o conflito de interesses deve ser analisado caso a caso - e após o exercício do voto pelo acionista."

\subsection{Abuso do Direito de Voto $x$ Conflito de Interesses}

Adicionalmente aos argumentos expostos, sustentam os formalistas a tese de que, se a análise da situação conflituosa se desse ex post, estar-se-ia inutilizando as letras do caput do artigo 115. Segundo explicam, a configuração do abuso do direito de voto já se dá a posteriori. Não haveria, portanto, necessidade de se elaborar dois dispositivos determinando um controle material do conflito. Nas palavras de Carvalhosa:

“(...) ao se exigir a ocorrência de prejuízo à companhia para a configuração de
'interesse conflitante', usa-se um conceito jurídico ocioso, dispensável ante a
proibição geral ao abuso do direito de voto, prevista no art. 115 da Lei das S.A.s.
Com efeito, se o voto com o fim de causar dano já é vetado pela lei em razão do seu
caráter abusivo, seria totalmente supérflua a previsão, no parágrafo $1^{\circ}$ desse
dispositivo, de um conflito de interesses que, do mesmo modo, só se configuraria
quando identificado o prejuízo ao interesse social. Se assim fosse, a lei teria
consagrado unicamente a proibição do abuso de direito de voto. (...)"113

Segue o mesmo entendimento Marcos Barbosa Pinto, diretor da CVM:

\footnotetext{
${ }^{112}$ REGO, Marcelo Lamy. Direito das Companhias. $1^{\mathrm{a}}$ ed. Rio de Janeiro: Forense, 2009. v. I, p. 425.
}

${ }^{113}$ CARVALHOSA. Modesto de Souza Barros. Revista Capital Aberto. ed. 89, 2010, p. 30. 
"Esse último ponto merece destaque. O caput do art. 115 diz expressamente que 'o acionista deve votar no interesse da companhia'; caso não o faça, seu voto será considerado abusivo. Se o conflito de interesses só pudesse ser apurado depois da deliberação, $o \S 1^{\circ}$ do art. 115 não faria sentido algum; ele nada acrescentaria ao caput do artigo. Esse não foi, obviamente, o propósito da lei, que se propôs a tratar de maneira distinta as duas situações, o abuso de voto e o conflito de interesses, como denota o próprio título do artigo em questão."114

Este argumento, apesar de aparentemente bastante sólido, não pode prosperar devido ao fato de que a diferenciação entre o caput e o parágrafo $1^{\circ}$ do artigo 115 tem seus alicerces em outro quesito. Vejamos, novamente, o que diz o caput:

"Art. 115. O acionista deve exercer o direito a voto no interesse da companhia; considerar-se-á abusivo o voto exercido com o fim de causar dano à companhia ou a outros acionistas, ou de obter, para si ou para outrem, vantagem a que não faz jus e de que resulte, ou possa resultar, prejuízo para a companhia ou para outros acionistas." (grifei)

Como se pode ver no trecho em destaque, ao utilizar a expressão com $o$ fim de, fica nítido que o legislador pretendia que se levasse em consideração a finalidade do voto, ou seja, a intenção do acionista no seu exercício. ${ }^{115}$ Diversos autores, dentre eles José Eduardo Tavares Borba, seguem esse mesmo entendimento de que o voto abusivo envolve sempre um elemento subjetivo: o dolo. ${ }^{116}$ Essa tese pode ser reforçada, inclusive, pela citação de Modesto de Souza Barros Carvalhosa, Alfredo Lamy Filho e José Luiz Bulhões Pedreira:

"A lei leva em conta a finalidade, ou seja, a intenção do acionista no exercício do direito de voto. O voto abusivo origina-se da figura do abuso do direito (abus de droit), que, em meio à grande discussão doutrinária, tem servido como padrão

\footnotetext{
${ }^{114}$ Voto do diretor Marcos Barbosa Pinto em face do Processo RJ2009/13179. Disponível no site da CVM <http://www.cvm.gov.br/port/descol/respdecis.asp?File=7190-2.HTM>. Acesso em 10 de maio de 2011.

${ }^{115}$ FRANÇA, Erasmo Valladão Azevedo e Novaes. Conflito de Interesses nas Assembléias de S.A.. ed. única São Paulo: Malheiros, 1993. p. 83.

COELHO, Fabio Ulhoa. Curso de Direito Comercial. $8^{\text {a }}$ ed. São Paulo: Saraiva, 2005. v. II, p. 312.

${ }^{116}$ BORBA, José Eduardo Tavares. Direito Societário. $9^{\text {a }}$ ed. Rio de Janeiro: Renovar. p. 329.
} 
normativo e de decisões jurisprudenciais. Insere-se a figura dos princípios gerais de direito." $" 117$

“(...) para verificar, em cada caso, a ocorrência de abuso no exercício do direito de voto, é indispensável que o juiz perquira os fins com que o acionista exerceu o voto, uma vez que a ilegalidade que vicia a deliberação da assembléia geral consiste em votar com o fim que não o interesse da companhia (...)."

Este elemento subjetivo, contudo, não está presente nas hipóteses de conflito de interesses. Nesse sentido, José Eduardo Tavares Borba afirma que "O voto conflitante é o que coloca o acionista em situação de conflito de interesses com a companhia, configurando uma colocação inteiramente objetiva. (...)"119 (grifou-se)

Deduz-se, consequentemente, que a diferença entre o abuso do direito de voto e o conflito de interesses, é que no primeiro caso sua verificação se dá com base em elementos subjetivos. Já na segunda hipótese, seu enquadramento se faz por meio da presença de elementos puramente objetivos. Portanto, a diferença, ao contrário do que diz a corrente formalista, não reside no fato da verificação da situação conflituosa se dar a priori ou a posteriori.

${ }^{117}$ CARVAlHOSA, Modesto de Souza Barros. Comentários à Lei das Sociedades Anônimas. $3^{\mathrm{a}}$ ed. São Paulo: Saraiva, 2003. v. II, p. 458 e 459.

${ }^{118}$ FRANÇA, Erasmo Valladão Azevedo e Novaes. Conflito de Interesses nas Assembléias de S.A.. ed. única São Paulo: Malheiros, 1993. p. 97. José Luiz Bulhões Pedreira e Alfredo Lamy Filho citados na nota 219. Prossegue o trecho: “(...) A prova da intenção do acionista somente pode basear-se, evidentemente, em elementos circunstanciais, já que o acionista que exerce o voto com violação da lei não revela sua intenção mas, ao contrário, procura disfarçá-la com a alegação do interesse da companhia. Essa sindicância da intenção do acionista não se confunde com a apreciação do mérito ou da conveniência da deliberação da assembléia: ainda que a decisão tomada pelo acionista ao exercer o direito de voto seja - segundo qualquer critério - errada ou inconveniente para a companhia, seu voto é válido se agiu de boa fé no interesse da companhia."

${ }^{119}$ BORBA, José Eduardo Tavares. Direito Societário. $9^{\text {a }}$ ed. Rio de Janeiro: Renovar. p. 329. 


\subsection{A Inversão do Princípio Majoritário}

O Princípio Majoritário, inspirado na organização representativa democrática do Estado ${ }^{120}$, é a regra que determina que devem prevalecer, nas deliberações dos órgãos colegiados da companhia, aquelas propostas que forem aprovadas pelo maior número de sujeitos e, quando conformes com a lei e o estatuto, vinculam todos os membros, ainda que ausentes ou dissidentes. ${ }^{121}$ No caso da assembleia geral, os sujeitos são as ações com direito de voto, forma pela qual o capital social é representado. Veja-se a seguir, as palavras de Nelson Eizirik nesse sentido:

“(...) a idéia que está na base do princípio majoritário é a de que, tanto o ordenamento social, como o de uma companhia, devem estar de acordo com o maior número de sujeitos (de ações, na companhia) e em desacordo com o menor número possível."122

Isso significa dizer que, no caso da assembleia geral, aquelas propostas aprovadas pelos acionistas que detiverem o maior número de ações com direito de voto $^{123}$, deverão prevalecer. Foi este o princípio adotado pelo legislador ao redigir a Lei das S.A. ${ }^{124}$, como vemos por meio da leitura do seu artigo 129:

${ }^{120}$ BULHÕES PEDREIRA, José Luiz; LAMY FILHO, Alfredo. Direito das Companhias. $1^{\text {a }}$ ed. Rio de Janeiro: Forense, 2009. v. I, p. 778 e 779: "Como observa Galgano (1984, p. 32), a expressão 'democracia acionária', que foi cunhada para representar o modelo oitocentista de sociedade anônima, exprimia de modo adequado as analogias que foram estabelecidas no século passado (XIX) entre a constituição do Estado e da sociedade anônima, entre a democracia política e a democracia econômica. A filosofia política, que pregava uma classe dirigente submetida ao juízo das assembléias de acionista e, mais em geral, ao 'juízo do mercado', expresso por uma multidão de grandes e pequenos poupadores nas negociações diárias da bolsa, sede de um controle social sobre a direção das empresas".

${ }^{121}$ EIZIRIK, Nelson. Mercado de Capitais, Regime Jurídico. $2^{\mathrm{a}}$ ed. Rio de Janeiro: Renovar. 2008. p. 393 ;

BULHÕES PEDREIRA, José Luiz; LAMY FILHO, Alfredo. Direito das Companhias. ${ }^{a}$ ed. Rio de Janeiro: Forense, 2009. v. I, p. 808.

${ }^{122}$ EIZIRIK, Nelson. Mercado de Capitais, Regime Jurídico. $2^{\mathrm{a}}$ ed. Rio de Janeiro: Renovar. 2008. p. 393 ;

${ }^{123}$ As ações com direito de voto são, em princípio, as ordinárias. E, conforme disposto no caput do artigo 110 da Lei das S.A., cada uma delas terá direito a somente um voto: "A cada ação ordinária corresponde 1 (um) voto nas deliberações da assembléia-geral.". As ações preferenciais sem direito a voto poderão adquiri-lo em situações excepcionais, como no caso do $\S 1^{\circ}$ do artigo 111 da Lei das S.A.: 
“Art. 129. As deliberações da assembléia-geral, ressalvadas as exceções previstas em lei, serão tomadas por maioria absoluta de votos, não se computando os votos em branco."

As exceções a que se refere o artigo 129 são tratadas no parágrafo $1^{\circ}$ desse mesmo artigo, onde se abre espaço para a determinação de maioria qualificada para a aprovação de determinados assuntos:

"Art. 129. $\S 1^{\circ}$. O estatuto da companhia fechada pode aumentar o quorum exigido para certas deliberações, desde que especifique as matérias."

O Princípio Majoritário encontra inúmeros defensores. Dois deles são Alfredo Lamy Filho e José Luiz Bulhões Pedreira, que reconhecem que "o funcionamento das sociedades por ações não prescinde do princípio majoritário (...)." 125

Fábio Konder Comparato junta-se a eles ao afirmar que, assim como nas demais jurisdições, no direito societário brasileiro a maioria deve comandar porque parte-se do pressuposto de que, como a sociedade existe no interesse dos sócios, e como ninguém, a princípio, pode decidir em nome do outro, prevalece a vontade sempre do maior número de partícipes. ${ }^{126}$

Um dos fortes argumentos na defesa de que a maioria deve comandar baseia-se no princípio da proporcionalidade do risco, que reza que aquele acionista que investiu a maior parte do capital da companhia e é quem incorre

“§ $1^{\circ}$ As ações preferenciais sem direito de voto adquirirão o exercício desse direito se a companhia, pelo prazo previsto no estatuto, não superior a 3 (três) exercícios consecutivos, deixar de pagar os dividendos fixos ou mínimos a que fizerem jus, direito que conservarão até o pagamento, se tais dividendos não forem cumulativos, ou até que sejam pagos os cumulativos em atraso."

${ }^{124}$ MARTINS, Fran. Comentários à Lei das S.A. $2^{\mathrm{a}}$ ed. Rio de Janeiro: Forense, 1984. v. 2, p. 203.

${ }^{125}$ BULHÕES PEDREIRA, José Luiz; LAMY FILHO, Alfredo. A Lei das S.A. $1^{\text {a }}$ ed. Rio de Janeiro: Renovar, 1992. v. III, p. 457.

${ }^{126}$ COMPARATO, Fabio Konder; SALOMÃO FILHO, Calixto. O Poder de Controle na Sociedade Anônima. $4^{\text {a }}$ ed. Rio de Janeiro: Forense. 2005. p.60. 
em maiores risco de prejuízos ou sucesso, deve ter seu poder político atrelado proporcionalmente à sua participação no capital social. ${ }^{127}$ Nesse sentido, as palavras de Fabio Ulhoa Coelho:

"Quem aportou mais recursos no capital social corre risco empresarial maior que o minoritário. O direito de participar das decisões da sociedade é relativo. Quanto mais o sócio contribuiu para o capital social, maior é o seu poder de influir nos negócios." 128

Segundo a corrente materialista, se impedíssemos o exercício do direito de voto dos acionistas com base numa interpretação formalista do parágrafo $1^{\circ}$ do artigo 115 da Lei das S.A., estaríamos invertendo o Princípio Majoritário e descartando a proporcionalidade do risco. Este argumento se baseia no fato de que, na prática, a grande maioria dos casos de conflito formal de interesses é deflagrada em situações que envolvem o acionista majoritário. ${ }^{129}$ Impedir que o direito de voto desse acionista seja exercido, acarretaria na transferência do poder decisório às minorias, justamente aqueles acionistas que, por representarem parcela mais reduzida do capital social, incorrem em menores riscos ante a tomada de uma decisão equivocada. Nesse sentido, manifestou-se o diretor da CVM Eli Loria, em face do julgamento do Processo Administrativo CVM n ${ }^{\circ}$ RJ2009/13179:

"O entendimento pelo controle a priori do voto inverte a lógica da lei societária de prevalência da maioria e, conforme destacado em votos proferidos em casos anteriores, impede de votar aquele que sofrerá um impacto relevante da decisão (por sua participação expressiva no capital social da companhia) e que melhor conhece os negócios sociais, confrontando o princípio da boa-fé que rege as relações comerciais,

\footnotetext{
${ }^{127}$ Existem exceções a esta proporcionalidade, como no caso de empresas emissoras de ações preferenciais sem direito de voto, possível graças ao disposto no artigo 111 da Lei das S.A..

${ }^{128}$ COELHO, Fabio Ulhoa. Curso de Direito Comercial. $8^{\mathrm{a}}$ ed. São Paulo: Saraiva, 2005. v. 2, p. 429.

${ }^{129}$ BULHÕES PEDREIRA, José Luiz; LAMY FILHO, Alfredo. Direito das Companhias. $1^{\mathrm{a}}$ ed. Rio de Janeiro: Forense, 2009. v. I, p. 840: Nesse sentido, ao tratar dos poderes do acionista controlador afirma que "Em matéria de contratacao com a companhia, que é um dos mais freqüentes - senão o mais frequente - caso em que pode ocorrer conflito de interesses, a Lei admite implicitamente a contratação, desde que em condições de não-favorecimento ou equitativas."
} 
sendo o exercício do voto regra geral que, aliás, constitui-se em um direito do acionista não-controlador e em um dever do acionista controlador." 130

Essa inversão pode ser ainda mais extremada graças a um fenômeno societário atual: o absenteísmo assemblear, notório tanto no Brasil como no exterior, e que está cada vez mais acentuado nas assembleias gerais de companhias abertas, como muito bem apontado por José Eduardo Tavares Borba:

\begin{abstract}
"Nas grandes companhias abertas, cujo capital votante se encontre disseminado no mercado, enfrenta-se o problema do absenteísmo dos acionistas nas assembléias. Essa ausência que, em muitos casos, se estende à maioria das ações faz com que às assembléias apenas compareça parcela minoritária do capital votante. Nestas circunstancias, a maioria será apurada em relação aos presentes, possibilitando a polarização do controle na maioria da minoria."131
\end{abstract}

Os materialistas alegam que o absenteísmo faria com que a decisão sobre a deliberação em que o controlador estivesse conflitado ficasse ainda mais restrita dentro de um pequeno grupo de acionistas minoritários.

A corrente formalista, por sua vez, não vê nisso um aspecto negativo. Alegam, inclusive, que ao dar maior importância relativa ao minoritário no processo decisório, ele se sentiria mais estimulado a participar das assembleias gerais. Argumento, este, usado por Norma Jonssen Parente no âmbito do julgamento do Inquérito Administrativo CVM No TA/RJ2001/4977:

"O fato de o controlador não votar propiciaria, sem dúvida, maiores discussões sobre a matéria, mais transparência e maior interesse dos demais acionistas, evitando, assim, questionamentos futuros. Que interesse teriam os acionistas minoritários de participar das discussões se antecipadamente já sabiam que o contrato seria inevitavelmente aprovado? Por outro lado, que interesse teria o controlador em

130 Voto do diretor Eli Loria em face do julgamento do Processo Administrativo CVM ${ }^{\circ}$ RJ2009/13179. Disponível no site da $\quad$ CVM <http://www.cvm.gov.br/port/descol/respdecis.asp?File=7190-0.HTM>. Acesso em 10 de maio de 2011.

${ }^{131}$ BORBA, José Eduardo Tavares. Direito Societário. 9a ed. Rio de Janeiro: Renovar, 2004. p. 334. 
apresentar as razoes que justificassem a celebração do contrato se não há necessidade do apoio dos minoritários?"132

Este argumento, contudo, mostra-se raso frente a uma análise mais cuidadosa dos fundamentos do absenteísmo dos minoritários. Conforme explicado por Fabio Ulhoa Coelho, os acionistas investidores não desejam participar das assembleias já que "cultivam um frio desinteresse pelo cotidiano das sociedades nas quais investem"133. Vejamos abaixo o que dizem José Luiz Bulhões Pedreira e Alfredo Lamy Filho também nesse sentido:

“(...) Os investidores de mercado querem aplicar capital e receber dividendos ou revender suas ações com lucro. Não se interessam por participar da administração da companhia (...). Esperam que o acionista controlador e os administradores resolvam essas questões com a maior eficiência, mantenham a companhia próspera e respeitem seus direitos. Se isso não ocorre, alienam suas ações, investem em outras companhias ou se retiram do mercado. E em geral não têm tempo nem capacidade técnica para viver todos os problemas da empresa ou das várias empresas em que investem. Exercem profissões e têm outros negócios, aplicam em ações como em qualquer outro tipo de investimento, para obter renda ou lucro, desde que não tenham que administrar os empreendimentos que geram esse lucro." ${ }^{134}$ (grifou-se)

Como visto acima, os motivos do não comparecimento dos minoritários à assembleia geral, pouco, ou mesmo nada tem a ver com seu peso político. Donde se entende, consequentemente, que dar-lhes a tarefa de tomar a decisão em caso de conflito formal do controlador pouco provavelmente teria alguma

${ }^{132}$ Voto da diretora Norma Jonssen Parente no âmbito do julgamento do Inquérito Administrativo CVM N $\mathrm{N}^{\circ}$ TA/RJ2001/4977. Disponível no site da CVM <http://www.cvm.gov.br/port/inqueritos/2001/rordinario/inqueritos/4977.asp>. Acesso em 10 de maio de 2011.

${ }^{133}$ COELHO, Fabio Ulhoa. Curso de Direito Comercial. $8^{\text {a }}$ ed. São Paulo: Saraiva, 2005. v. 2, p. 272 a 273: "Como se pode imaginar, são diferentes os graus de vinculação do acionista à companhia, nos três casos. Enquanto os empreendedores costumam nutrir especial apreço pela história da companhia, entusiasmam-se com as particularidades da atividade econômica desenvolvida, animam-se com a concorrência no segmento de mercado específico, sofrem com as dificuldades da empresa e se sentem gratificados com os sucessos alcançados, os investidores debruçam-se sobre informações econômicas, satisfazem-se com números das demonstrações financeiras, e cultivam frio desinteresse pelo cotidiano das sociedades nas quais investem. Entre os rendeiros e especuladores, pode-se visualizar também um grau diverso de vínculo com a companhia, um pouco maior naqueles e quase nenhum nestes. Nas temporadas de ataque às moedas dos países em desenvolvimento, rendeiros se preocupam e especuladores vibram."

${ }^{134}$ BULHÕES PEDREIRA, José Luiz; LAMY FILHO, Alfredo. Direito das Companhias. $1^{\text {a }}$ ed. Rio de Janeiro: Forense, 2009. v. I, p. 781. 
influência significativa no absenteísmo assemblear. Mais provável é que esses acionistas continuem a exercer seu papel de meros investidores de capital.

A corrente materialista alega, por fim, que tal decisão aumentaria o risco sobre a condução dos negócios sociais podendo, inclusive, prejudicar os próprios minoritários a médio e longo prazo. Deve-se isso ao fato de que a transferência do poder decisório passaria das mãos daquele acionista tecnicamente mais preparado e que melhor conhece a empresa para os minoritários que, como bem dito por José Luiz Bulhões Pedreira e Alfredo Lamy Filho, não têm capacidade técnica para gerir os problemas da empresa. ${ }^{135}$ Vejamos, nesse sentido, o que disse o ex-diretor da CVM Luiz Antonio de Sampaio Campos no âmbito do julgamento do Inquérito Administrativo CVM $n^{\circ}$ RJ2001/4977:

\begin{abstract}
"Recordo aqui, inclusive, o fato de que, no caso do acionista controlador, ao se the exigir a abstenção, a lei estaria retirando de suas mãos a decisão primeira sobre o interesse social, muito embora fosse ele quem estivesse em melhor condição para julgar a adequação de determinada deliberação ao interesse social, pois, ao menos teoricamente, é ele quem, dentre os acionistas, melhor conhece a situação da companhia, acompanha de perto seus negócios e que está com ela mais comprometido." 136
\end{abstract}

\title{
3.6. Abuso das Minorias
}

Os materialistas alegam que ao se impedir o acionista conflitado de votar que, ressalte-se, é o controlador na maioria das vezes, estar-se-ia abrindo

\footnotetext{
${ }^{135}$ BULHÕES PEDREIRA, José Luiz; LAMY FILHO, Alfredo. Direito das Companhias. $1^{\text {a }}$ ed. Rio de Janeiro: Forense, 2009. v. I, p. 782: “(...) fato notório de que em toda companhia aberta há duas espécies irredutíveis de acionistas: o empresário-empreendedor, que cria e expande a empresa, a ela se dedica permanentemente e profissionalmente, vive todos os seus problemas, e se realiza nessa atividade; e o investidor de mercado que pretende, tão somente, aplicar o capital".

${ }^{136}$ Luiz Antonio de Sampaio Campos no âmbito do julgamento do Inquérito Administrativo CVM no RJ2001/4977. Disponível no site da $\quad$ CVM <http://www.cvm.gov.br/port/inqueritos/2001/rordinario/inqueritos/4977.asp>. Acesso em 10 de maio de 2011.
} 
espaço para o abuso da minoria, ocasionando, muitas vezes, a própria inviabilidade do negócio e, finalmente, acarretando um prejuízo à sociedade. Esse risco é inclusive reconhecido por formalistas confessos, tais como Marcos Barbosa Pinto, diretor da CVM:

"Mas não seria arriscado demais remediar essa situação concedendo um poder de
veto aos acionistas minoritários? Não custa lembrar que muitas companhias
brasileiras têm free float baixo e que o absenteísmo nas assembléias brasileiras é
bastante elevado. Portanto, é considerável o risco de que a decisão em questão fique
nas mãos de minoritários pouco representativos, que podem ser movidos, inclusive,
por interesses ilegítimos."

Os formalistas, contudo, fortemente combatem essa tese alegando que existem remédios jurídicos aplicáveis inclusive para o caso de voto abusivo da minoria. Tal remédio está previsto no próprio artigo 115, especialmente o seu parágrafo $3^{\circ}$. Vejamos como Modesto de Souza Barros Carvalhosa se manifestou acerca do tema:

\begin{abstract}
"Essa visão psicológica do comportamento dos minoritários, na espécie, não parece encontrar fundamento na prática. Ademais, se configurado esse quadro, sobre tal conduta incidirão as cominações da lei por abuso de direito de voto. A configuração do ilícito, no caso, é flagrante. Não pode, com efeito, a minoria, a quem se atribui o encargo de votar as contas dos acionistas administradores e dos acionistas conferentes de bens de capital, abusar da prerrogativa de voto ao formar o colégio decisório da assembléia geral, deliberando contrariamente ao interesse social e dos demais acionistas, por mera emulação ou para obter vantagens." 138
\end{abstract}

Nas palavras de Marcos Barbosa Pinto:

"Quanto aos minoritários oportunistas, não é preciso ir muito longe para a encontrar o instrumento com o qual combatê-los: o próprio impedimento de voto. Como vimos acima, um acionista que não tenha interesse conflitante não tem nenhum incentivo para votar contra uma operação benéfica à companhia. Portanto, se queremos coibir o

\footnotetext{
${ }^{137}$ Voto do diretor da CVM Marcos Barbosa Pinto face ao Processo RJ2009/13179. Disponível no site da CVM <http://www.cvm.gov.br/port/descol/respdecis.asp?File=7190-2.HTM>. Acesso em $10 \mathrm{de}$ maio de 2011.

${ }^{138}$ CARVAlHOSA, Modesto de Souza Barros. Comentários à Lei das Sociedades Anônimas. $3^{\mathrm{a}}$ ed. São Paulo: Saraiva, 2003. v. II, p. 465.
} 
voto oportunista, o melhor a fazer é justamente identificar os conflitos de interesse e impedir o acionista conflitado de votar, seja ele controlador ou minoritário."139

$\mathrm{O}$ argumento formalista, a primeira vista, parece sólido. Contudo, feita uma análise mais delicada, percebe-se que ele não pode prosperar frente aos fatos impostos pela realidade. Ocorre que essa solução requer que se prove que cada um dos acionistas minoritários que votaram contra a deliberação o fizeram de forma abusiva. Na prática, isto seria impossível dado o número imenso de minoritários em companhias abertas. Além disso, seria extremamente difícil e caro encontrar provas para reverter cada um desses votos. A recuperação dos prejuízos causados, por meio de perdas e danos, acresça-se, sofreria com a morosidade e a dificuldade de execução de uma eventual vitória judicial.

Os materialistas, quanto a esse ponto, alegam que seria infinitamente mais fácil reverter uma decisão do controlador conflitado ou responsabilizá-lo por perdas e danos do que fazer o mesmo com cada um dos acionistas minoritários. Os riscos de se impedir o controlador de votar, dessa forma, seriam muito maiores.

\subsection{O Princípio da Presunção de Boa-Fé}

Etimologicamente, a boa-fé deriva do latim bona fides, que significa fidelidade, crença, confiança, sinceridade, convicção interior. O Princípio da Presunção da Boa-Fé reza que deve-se partir do pressuposto que ambas as

\footnotetext{
${ }^{139}$ Voto do diretor Marcos Barbosa Pinto face ao julgamento do Processo Administrativo CVM no RJ/2009/13179. Disponível no $\quad$ site $\quad$ da $\quad$ CVM <http://www.cvm.gov.br/port/descol/respdecis.asp?File=7190-2.HTM>. Acesso em 10 de maio de 2011.
} 
partes realizarão o negócio jurídico em respeito à lei, às boas práticas do mercado e à ética.

Esse Princípio permeia nosso ordenamento jurídico em diversos pontos, mas encontra sua referência basilar no artigo 113 da Lei 10.406, de 10 de janeiro de 2002, o Código Civil Brasileiro:

“Art. 113. Os negócios jurídicos devem ser interpretados conforme a boa-fé e os usos do lugar de sua celebração."

Tal Princípio é aplicado, inclusive, ao direito empresarial. A Lei das S.A. faz em diversos dispositivos referência à boa-fé. Dentre eles, o parágrafo $1^{\circ}$ do artigo $107^{140}$, parágrafo $6^{\circ}$ do artigo $159^{141}$ e o parágrafo $2^{\circ}$ do artigo $201^{142}$.

Um dos argumentos da corrente materialista em prol de seu entendimento é que impedindo o exercício do direito de voto com base no parágrafo $1^{\circ}$ do artigo 115 , estar-se-ia afastando o Princípio da Presunção da Boa-Fé. Vejamos, nesse sentido, o que disse Luiz Antonio Sampaio Campos face ao julgamento do Inquérito Administrativo CVM No TA/RJ2001/4977:

\begin{abstract}
"A presunção a priori é algo, a meu ver, muito violento e assistemático dentro do regime do anonimato, pois afasta a presunção de boa-fé, que me parece ser a presunção geral e mais tolhe um direito fundamental do acionista ordinário que é o direito de voto, no pressuposto de que ele não teria como resistir à tentação. Dito de outra forma, estar-se-ia a expropriar o direito de voto do acionista no pressuposto de que ele poderia vir a prejudicar a companhia mediante o seu exercício, em virtude de
\end{abstract}

\footnotetext{
${ }^{140}$ Art. 107. $\S 1^{\circ}$. Será havida como não escrita, relativamente à companhia, qualquer estipulação do estatuto ou do boletim de subscrição que exclua ou limite o exercício da opção prevista neste artigo, mas o subscritor de boa-fé terá ação, contra os responsáveis pela estipulação, para haver perdas e danos sofridos, sem prejuízo da responsabilidade penal que no caso couber.

${ }^{141}$ Art. 159 . $\S 6^{\circ}$. O juiz poderá reconhecer a exclusão da responsabilidade do administrador, se convencido de que este agiu de boa-fé e visando ao interesse da companhia.

142 Art. 201. $\S 2^{\circ}$ Os acionistas não são obrigados a restituir os dividendos que em boa-fé tenham recebido. Presume-se a má-fé quando os dividendos forem distribuídos sem o levantamento do balanço ou em desacordo com os resultados deste.
} 
um aparente conflito de interesse. Haveria a presunção de que o acionista perpetraria uma ilegalidade acaso fosse lícito que proferisse o seu voto, numa espécie de consagração da fraqueza humana. Prefiro, em situações genéricas, entender que as pessoas cumprem a lei, que não se deixam trair por seus sentimentos egoísticos, porque, como disse, a boa-fé é a regra igualmente o cumprimento da lei e a inocência. Ora, se isto não fosse verdade, talvez fosse melhor não haver sociedade, pois a confiança é algo fundamental nas relações societárias, até mesmo nas companhias abertas, pois ninguém, em sã consciência, gostaria de ser sócio de alguém em que não confia, principalmente se este alguém for o acionista controlador. Parece-me, assim, evidente a distorção, pois a presunção de hoje e sempre é que as pessoas cumprem a lei."

\section{No mesmo sentido, Julio Costas Comesaña:}

"Consideramos que un deber general de abstención de voto es excesivo. En primer lugar, porque no parece que pueda presumirse iuris et de iure que el socio se decantará siempre por el interés extrasocial ante cualquier clase de conflicto con el interés social. En segundo lugar, si se considera como parece razonable que es la Junta General la competente para decidir cuando existe conflicto de intereses al margen de las situaciones enumeradas por la LSRL, también parece igualmente razonable estimar que el socio o socios en conflicto no pueden participar en esta votación previa, con lo que estaríamos invirtiendo la regla de la mayoría propiciando el abuso de la minoría, pero también, si el socio interesado forma parte de la minoría, el deber genérico de abstención de voto puede convertirse en un instrumento de la mayoría para expropiar los derechos de la minoría reconocidos por la Ley." "143

A corrente formal, por sua vez, rebate esse argumento alegando, principalmente, que a abstenção de voto se trata de uma regra de natureza precaucionária. Nesse sentido, manifestou-se o diretor da CVM Otávio Yazbek no julgamento do Processo Administrativo CVM no RJ2009/13179:

\footnotetext{
"Isso me leva ao último dos pontos que gostaria de, nesta instância, analisar que é o do caráter profilático ou precaucionário, já referido, de uma opção legal dessa natureza. Com efeito, ainda que se deva, usualmente, presumir a boa-fé das partes, nada impede que a lei estipule regimes de prevenção, em especial quando há uma posição privilegiada para um determinado agente econômico ou marcadas assimetrias informacionais em favor deste."
}

\footnotetext{
${ }^{143}$ COMESAÑA, Julio Costas. El Deber de Abstención del Socio en las Votaciones. Valencia: Tirant lo Blanch, 1999, p. 61, conforme citação do diretor da CVM Luiz Antonio Luiz Antônio, em face do julgamento do Processo Administrativo Sancionador CVM TA/RJ2001/4977. Disponível no site da CVM <http://www.cvm.gov.br/port/inqueritos/2001/rordinario/inqueritos/4977.asp>. Acesso em $10 \mathrm{de}$ maio de 2011.
} 
Junta-se a ele, em defesa da abstenção, Norma Jonssen Parente e Marcos Barbosa Pinto, cujos extratos abaixo fazem parte de seus votos manifestados no âmbito do julgamento do Inquérito Administrativo CVM No TA-RJ2002/1153, e do Processo RJ2009/13179, respectivamente:

\begin{abstract}
"Novamente o elemento psicológico é afastado da apreciação objetiva do conflito. A regra da lei n. ${ }^{\circ}$ 6.404/76 é comando jurídico e não simples regra moral. $\underline{\mathrm{O} \text { acionista }}$ não é o juiz soberano para decidir sobre a existência ou não do conflito, sabido que o mesmo é puramente formal. Do contrário, fosse um comando moral, efeito inerente da corrente que defende as considerações substancias e ex post do conflito, a decisão do acionista seria soberana e incontrastável frente até ao Judiciário, já que o análise do animus daquele seria praticamente impossível." (grifou-se)

“(...) E, sinceramente, não vejo nela qualquer contrariedade com o princípio da presunção de inocência. Esse princípio diz que uma pessoa não pode ser considerada culpada de um ato ilícito antes da apreciação de sua conduta pelo órgão julgador. Ele não diz que a lei deve, ao definir quais condutas serão consideradas ilícitas, presumir que todos os indivíduos se portam sempre de maneira exemplar."
\end{abstract}

\title{
3.8. Conflito de Interesses $x$ Benefício Particular
}

Como sabemos, o legislador incorporou ao parágrafo $1^{\circ}$ do artigo 115 os casos de votação sobre benefício particular. Ao fazê-lo, contudo, o legislador arrastou esse termo ao cerne do debate sobre a interpretação do conflito de interesses.

A controvérsia em questão baseia-se em dois pontos. Primeiramente, existe uma corrente confusão entre os institutos jurídicos do conflito de interesses e do benefício particular. O segundo aspecto está na forma de enquadrar ao termo, o impedimento de voto previsto no parágrafo $1^{\circ}$ do artigo 115. Faz-se, portanto, necessária uma breve análise do instituto. 
Como visto no Capítulo 2 desta obra, a expressão benefício particular, utilizada no parágrafo $1^{\circ}$ do artigo 115 da Lei das S.A., tem, assim como o termo conflito de interesses, suas raízes históricas fincadas na Lei 3.150 de 1882. Vale relembrarmos o que dizia o artigo 15 , parágrafo $10^{\circ}$ da referida Lei:

“§10. Não podem votar nas assembléas geraes os administradores para approvarem seus balanços, contas e inventarios, os fiscaes os seus pareceres, e os accionistas a avaliação de seus quinhões, ou quaesquer vantagens estipuladas nos estatutos ou contrato social." 144 (sic) (grifou-se)

Posteriormente, com a promulgação do Decreto-Lei 2.627, adotou-se a expressão benefício conforme se vê abaixo no seu artigo 82:

“Art. 82. O acionista não pode votar nas deliberações da assembléia geral relativas ao laudo de avaliação dos bens com que concorrer para a formação do capital social, nem nas que venham a beneficiá-lo de modo particular."

Mas, afinal, o que é o benefício particular? Conforme muito bem definido por Rubens Requião, citado por Marcelo Lamy Rego: "Não são vantagens que acionistas, ou grupo deles, venham, em conjunto, gozar, mas vantagens que favoreçam o acionista isoladamente, de "modo particular"”. ${ }^{46}$

Este conceito de benefício particular, contudo, é muitas vezes confundido com o conflito de interesses. Modesto de Souza Barros Carvalhosa entende que o conflito de interesses estaria incorporado ao conceito de benefício particular:

\footnotetext{
${ }^{144}$ Disponível no site do Planalto <http://www.planalto.gov.br/ccivil_03/LEIS/1851-1900/L3150.htm> . Acesso em 10 de maio de 2011.

145 Disponível no site do Planalto < http://www.planalto.gov.br/ccivil/Decreto-Lei/Del2627.htm>. Acesso em 10 de maio de 2011.

${ }^{146}$ REGO, Marcelo Lamy. Direito das Companhias. $1^{\mathrm{a}}$ ed. Rio de Janeiro: Forense, 2009. v. I, p. 413.
} 
"O conflito de interesses também ocorre quando a deliberação da assembléia geral beneficiar alguns acionistas e não outros." 147

Os dois conceitos, contudo, devem ser vistos de forma distinta. Mas qual a diferença entre eles? A diferença é que o conflito de interesses é de uma vantagem ilícita, prejudicial aos interesses da sociedade e dos demais acionistas. Já o benefício particular seria uma vantagem lícita, permitida por lei e prevista no estatuto social da companhia. Nesse sentido, Erasmo Valladão Azevedo e Novaes França, Modesto de Souza Barros Carvalhosa e Trajano de Miranda Valverde, citado por Marcelo Lamy Rego:

"A vantagem conferida a um ou mais acionistas, comumente, consiste em uma participação nos lucros líquidos da sociedade, durante certo tempo, ou no direito, algumas vezes extensivo aos herdeiros, de receber determinada soma, por mês, ou anualmente, a título de pensão ou aposentadoria."148

"Nesse benefício restrito, a lei não pressupõe a existência de um ilícito ou de qualquer intenção do beneficiado no sentido de lesar a companhia ou os demais acionistas." 149

"O Próprio Valverde dá como exemplo de tais vantagens a bonificação de ações, o direito de preferência ou o direito estatutário de receber pensão ou aposentadoria, que são vantagens perfeitamente lícitas, mas que podem ter o condão de quebrar o princípio da igualdade de tratamento dos acionistas."150

Outra diferença fundamental entre os dois institutos é que no caso de benefício particular existe somente uma prestação unilateral da companhia em prol do acionista. Diferentemente da situação de conflito de interesses em que existe, necessariamente, uma contraprestação da parte beneficiada. Ou seja,

${ }^{147}$ CARVAlhOSA, Modesto de Souza Barros. Comentários à Lei das Sociedades Anônimas. $3^{\mathrm{a}}$ ed. São Paulo: Saraiva, 2003. v. II, p. 466.

${ }^{148}$ FRANÇA, Erasmo Valladão Azevedo e Novaes. Conflito de Interesses nas Assembléias de S.A.. ed. única São Paulo: Malheiros, 1993. p. 73

${ }^{149}$ CARVAlHOSA, Modesto de Souza Barros. Comentários à Lei das Sociedades Anônimas. $3^{\mathrm{a}}$ ed. São Paulo: Saraiva, 2003. v. II, p. 466.

${ }^{150}$ REGO, Marcelo Lamy. Direito das Companhias. $1^{\mathrm{a}}$ ed. Rio de Janeiro: Forense, 2009. v. I, p. 413. 
apesar de frequentemente confundido, a contratação com a companhia não é caso de benefício particular, mas caso de conflito de interesses formais.

E quanto à aplicação do impedimento de voto? Há juristas que, alegam que o benefício particular deveria ter o mesmo tratamento do conflito de interesses material. Outros, baseados no princípio do nemo iudex in causa propria $^{151}$, entendem que a deliberação sobre benefício particular, tal como as votações sobre laudo de avaliação ou aprovação de contas, seria um caso de proibição de voto. Neste sentido manifesta-se Erasmo Valladão Azevedo e Novaes França:

"Pode-se concluir, assim, que, na hipótese de deliberação que beneficie o acionista de modo particular, está-se também, tal como nas duas primeiras hipóteses previstas no $\S 1^{\circ}$ do art. 115 , diante de um caso de divieto di voto, sendo nulo o voto proferido em desrespeito à proibição, independentemente de qualquer indagação acerca do conteúdo da deliberação ou de eventual prejuízo, potencial ou atual, à companhia." ${ }^{\text {"152 }}$

Junta-se a ele, Marcelo Lamy Rego:

“As três primeiras hipóteses, são hipóteses, são hipóteses às quais a lei dá tratamento semelhante ao divieto di voto, tendo o legislador prescrito situações formais em que o acionista não pode exercer o voto."153

\subsection{A Lei 10.303 de 2001}

\footnotetext{
${ }^{151}$ FRANÇA, Erasmo Valladão Azevedo e Novaes. Conflito de Interesses nas Assembléias de S.A.. ed. única São Paulo: Malheiros, 1993. p. 89.

CARVALHOSA, Modesto de Souza Barros. Comentários à Lei das Sociedades Anônimas. $3^{\mathrm{a}}$ ed. São Paulo: Saraiva, 2003. v. II, p. 466: Nesse sentido, Carvalhosa alega que "O impedimento de voto tem como base o envolvimento pessoal do acionista para intervir na decisão de um negócio jurídico em que ele é especialmente interessado."

${ }^{152}$ FRANÇA, Erasmo Valladão Azevedo e Novaes. Conflito de Interesses nas Assembléias de S.A.. ed. única São Paulo: Malheiros, 1993. p. 90 - 91.

${ }^{153}$ REGO, Marcelo Lamy. Direito das Companhias. $1^{\text {a }}$ ed. Rio de Janeiro: Forense, 2009. v. I, p. 411.
} 
Propunha a Lei 10.303 de 31 de outubro de 2001 a inclusão dos parágrafos $5^{\circ}$ a $10^{\circ}$ no artigo 115 da Lei das S.A. Esses dispositivos possibilitavam a convocação de assembleia geral para deliberar sobre a existência de conflito de interesses em transações que envolvessem a companhia e seus acionistas. Pretendia, desse modo, facilitar a caracterização da situação conflituosa a fim de impedir o acionista conflitado de exercer seu direito de voto.

O Poder Executivo, contudo, decidiu vetar a inclusão desses perágrafos. Dentro das exposições de motivos para o veto, destacam-se os seguintes extratos referentes ao artigo 115:

\begin{abstract}
"A necessidade de se vetar os parágrafos acima transcritos decorre de manifesto conflito com o interesse público, em razão da constatação de que a assembléia para deliberação acerca da existência de conflito de interesses de que tratam os citados dispositivos se afigura inócua em termos de proteção ao acionista minoritário. Com efeito, não há como afastar o voto do acionista controlador no conclave pretendido sob pena de se atribuir aos minoritários o inédito poder de, indiretamente, vetar qualquer deliberação a partir da alegação de existência de conflito do controlador, e de se desconsiderar o próprio conflito de interesses do minoritário na assembléia especial, o que demonstra a inexistência de efetividade na proposta apresentada."
\end{abstract}

"Em realidade, as regras acima enfocadas trariam, na prática, apenas confusão, podendo, inclusive, servir para supostamente confirmar a inexistência de um conflito cuja presença caberia ao Poder Judiciário avaliar, ou mesmo para motivar um aumento de ações judiciais envolvendo o controvertido tema de que se cuida." 154

Como pode-se facilmente observar nos trechos em destaque, não pretende o Estado permitir a outorga aos minoritários da competência de identificar o conflito de interesses, por entender que estar-se-ia abrindo espaço para o abuso desses acionistas. Pelo contrário, essa tarefa caberia somente ao Poder Judiciário. Donde se entende, consequentemente, que a análise de tal

\footnotetext{
${ }^{154}$ Mensagem da Subchefia para Assuntos Jurídicos no 1.213, DE 31 DE OUTUBRO DE 2001. Disponível no site do em <http://www.planalto.gov.br/ccivil/leis/Mensagem_Veto/2001/Mv1213-01.htm〉. Acesso em $10 \mathrm{de}$ maio de 2011.
} 
situação far-se-á posteriormente à tomada da deliberação, exatamente como defendem os adeptos à corrente material. 


\section{CAPÍTULO 4 \\ A Comissão de Valores Mobiliários}

\subsection{A CVM}

Foi por meio da Lei $n^{\circ}$ 6.385, de 07 de dezembro de 1976, que se determinou a criação da CVM. Essa lei passou a ser conhecida, posteriormente, como a Lei do Mercado de Valores Mobiliários, já que não somente criava a referida autarquia, mas também procurava regular o mercado de valores mobiliários em complementação à Lei das S.A. e à Lei $\mathrm{n}^{\circ} 4.728$, de 14 de julho de 1965, que inaugurou no direito brasileiro a distinção entre companhias abertas e fechadas.

A CVM é uma entidade autárquica em regime especial com autonomia administrativa e orçamentária. Sua criação foi inspirada na Securities and Exchange Comission, autarquia reguladora e fiscalizadora do mercado de valores mobiliário americano, criada em $1934 .{ }^{155}$

A competência da CVM baseia-se na normatização das operações com valores mobiliários, na autorização de sua emissão e negociação, assim como a de fiscalização das sociedades anônimas abertas e dos agentes que operam no mercado de capitais. ${ }^{156}$

Este capítulo traz uma série de casos em que a CVM se manifestou acerca da interpretação do termo conflito de interesses constante do parágrafo $1^{\circ}$ do artigo 115 da Lei das S.A.. Essas manifestações deram-se por vezes com base em sua competência de fiscalizar, em que, tendo ou não sido provocada, a

\footnotetext{
${ }^{155}$ COELHO, Fabio Ulhoa. Curso de Direito Comercial. $8^{\mathrm{a}}$ ed. São Paulo: Saraiva, 2005. v. 2 , p. 72.

${ }^{156}$ COELHO, Fabio Ulhoa. Curso de Direito Comercial. $8^{\mathrm{a}}$ ed. São Paulo: Saraiva, 2005. v. 2, p. 72.
} 
CVM se propõe a averiguar ilegalidades e impor condutas ou sanções com o objetivo de prevenir ou reprimir danos aos investidores.

Outras manifestações, contudo, deram-se com base em sua competência de exercer atividade consultiva, por meio de suas "manifestações de entendimento", objetivando trazer maior segurança jurídica ao mercado de capitais. Essas consultas de caráter interpretativo são, normalmente, motivadas por consultas ou reclamações e vinculam a Administração Pública quanto à opinião esposada naquele caso.

A administração da CVM compete a um colegiado composto por cinco membros, sendo um presidente e quatro diretores, todos nomeados pelo Presidente da República depois de aprovados pelo Senado Federal. O mandato dos membros é de cinco anos, sendo vedada a sua recondução.

\subsection{Histórico de Decisões da CVM}

\subsubsection{O Caso TIM}

Em 25 de abril de 2000 foi realizada assembleia geral extraordinária da CTMR Celular S.A. (“CMTR”), controlada diretamente pela Tele Celular Sul Participações S.A. ("TCS"). Nela, foi aprovado, por unanimidade dos acionistas presentes - incluída a contagem do voto manifestado pela TCS - o pagamento de $1 \%$ da receita líquida da CMTR à título de royalties pelo uso da sua marca à Telecom Itália Móbile ("TIM"), empresa também controlada pela TCS, mas de forma indireta. 
A Superintendência de Relações com Empresas ("SEP”) - órgão vinculado à CVM -, por entender que havia abuso de poder e conflito de interesses por parte da TCS no exercício de voto na assembleia, interpôs o termo de acusação na CVM. Instaurado o Processo Administrativo Sancionador CVM no TA/RJ2001/4977 ${ }^{157}$, questionou-se sobre a possibilidade do exercício regular do voto da controladora TCS e sobre seu conteúdo, em face do disposto no caput e parágrafo $1^{\circ}$ do artigo 115 da Lei das S.A..

Julgado em 19 de dezembro de 2001, prevaleceu no órgão colegiado da autarquia - por maioria de votos - o entendimento de que, pelo fato de a TCS figurar em posições contratuais opostas - como controladora direta da CTMR e indireta da TIM -, haveria, necessariamente, conflito de interesses. Adotou-se, portanto, a corrente doutrinária do conflito formal de interesses donde deriva o entendimento que a situação conflituosa seria verificável $a$ priori.

$\mathrm{O}$ voto vencedor foi liderado pela diretora relatora Norma Jonssen Parente, que defendeu que a acionista controladora TCS deveria ter se considerado impedida de votar em assunto em que tinha interesse conflitante ou que a beneficiava de modo particular. Alegou não ser sequer necessária a verificação de que os interesses da TCS estavam contrapostos aos da CTMR:

“(...) o benefício do controlador decorre do próprio contrato, por figurar ele nos dois lados, razão pela qual deveria abster-se de votar, independentemente de o contrato ser ou não equitativo. (...) o conflito de interesses não pressupõe que os interesses sejam opostos, mas que o acionista tenha duplo interesse".

Argumento este, duramente criticado no voto do diretor Luiz Antonio de Sampaio Campos, que tratou de definir com mais clareza, apoiado na doutrina

\footnotetext{
157 Disponível no site da $\quad$ CVM <http://www.cvm.gov.br/port/inqueritos/2001/rordinario/inqueritos/4977.asp>. Acesso em 10 de maio de 2011.
} 
nacional e estrangeira, o que seria o verdadeiro conflito. Luiz Antonio, único a manifestar-se em sentido oposto, afirmou que o conflito de interesses seria aquela situação onde não existe a possibilidade de convergência ou conciliação entre esses dois interesses, sendo inevitável que se sacrifique um em face do outro. A sua caracterização, ainda, só poderia ser verificada a posteriori, ao analisar-se caso concreto. Seguiu, assim, a corrente doutrinária do conflito material:

“(...) deve-se permitir ao acionista [controlador] votar, na suposição de que ele não faltará com os deveres que lhe são impostos no artigo 115, caput, e no artigo 116, parágrafo único (...); mas comprovado, por ligeiramente que seja, que este faltou com o seu dever, seu voto será tido como ilegal e a deliberação poderá ser anulada, se este voto tiver sido determinante para a formação da maioria necessária à validade da deliberação."

Além disso, o diretor Luiz Antonio defendeu que somente o próprio acionista saberia de antemão qual interesse iria privilegiar e que, por isso, ele seria o único capaz de avaliar seu estado de interesse conflitante.

Já o diretor Marcelo Fernandes Trinidade, discordou de Norma Parente no que tange o abuso do direito de voto pelos diretores da companhia. Segundo ele, não havia elementos de prova capazes de autorizar a afirmação de que o voto tenha sido exercido em prejuízo da companhia, ou que as condições contratuais não fossem equitativas. Entretanto, acompanhou a relatora no que concerne à abstenção do exercício do voto, não com base no conflito de interesses, mas por entender que a contratação com a companhia enquadrar-seia na hipótese do benefício particular:

“(...) entendo que na deliberação sobre a celebração de um contrato bilateral entre a companhia e o acionista está previamenre impedido o voto deste último, não porque enxergue necessariamente no contrato um conflito de interesses - interesses que, aliás, normalmente convergem -, mas porque nele vejo um benefício particular (a contraprestação), benefício este que, concedido ao acionista contratante, não é estendido aos demais acionistas, por razoes óbvias. (...) A meu juízo, nesses casos o 
acionista deve abster-se de votar, em obediência à regra do $\S 1^{\circ}$ do art. 115 da Lei $6.404 / 76$, pois a regra do impedimento do voto deve ser posta em prática previamente à deliberação."

Os diretores Wladimir Caselo Branco Castro e José Luiz Osorio de Almeida Filho acompanharam o voto da relatora. Todavia, este, acrescentou o seguinte:

“(...) entendo que à CVM não cabe analisar o mérito desses contratos [de royalties], substituindo o acionista no exercício do seu poder de voto. Porém, deve ela cuidar para que haja a devida transparência acerca das circunstâncias que envolvem esse tipo de contratação."

Este Processo foi posteriormente alvo do Recurso Voluntário 4120, perante o Conselho de Recursos do Sistema Financeiro Nacional ("CRSFN"), órgão recursal na esfera administrativa e vinculado ao Ministério da Fazenda. Este órgão, contudo, negou - por maioria de votos - o provimento do recurso por entender que a interpretação mais adequada para a parte final do dispositivo em tela deveria ser que o voto do acionista que se considerar em conflito é vedado a priori. Entretanto, acrescentou o CRSFN que é o próprio acionista quem deve julgar se está ou não conflitado e se ele não o fizer, essa situação deverá ser verificada em fase ulterior, levando-se em conta apenas os aspectos formais. Manteve, assim, a decisão da CVM.

O entendimento de que o conflito de interesses seria material, expressado pelo voto do diretor Luiz Antonio, inicialmente minoritário, ganhou forças na CVM e passou a ser majoritário q partir do julgamento do "Caso PREVI", que analisaremos a seguir. 


\subsubsection{O Caso PREVI}

Em 30 de novembro de 1999, os acionistas da Tele Norte Leste Participações S.A. (“TNLP”) aprovaram, em assembleia geral extraordinária, um acordo de prestação de serviços gerenciais entre a TNLP e sua controladora, a Telemar Participações S.A. (“TELEMAR”).

Apesar da TELEMAR ter se abstido de votar na assembleia, a SEP, baseada no fato de a Caixa de Previdência dos Funcionários do Banco do Brasil ("PREVI") e a Fundação Sistel de Seguridade Social ("SISTEL") possuírem participações indiretas tanto na TNLP como diretas na TELEMAR, identificou um possível conflito de interesses. Propôs, então, a abertura de inquérito administrativo para a apuração completa dos fatos, com eventual imposição de penalidades às acionistas PREVI e SISTEL que exerceram seu direito de voto.

Instaurado o Processo Administrativo Sancionador CVM $\mathrm{n}^{\circ}$ TA/RJ2002/1153 ${ }^{158}$, foi esse julgado em 6 de novembro de 2002, tendo prevalecido o entendimento de que não havia conflito de interesses, com base na corrente substancialista.

O voto vencedor foi liderado pelo diretor Luiz Antonio de Sampaio Campos, derrotado no julgamento do caso anterior e seguido pelos diretores Luiz Leonardo Cantidiano - presidente da CVM à época - e Wladimir Castelo Branco Castro que, como é de se observar, mudou de entendimento. Restou vencida a diretora relatora Norma Jonssen Parente, que havia liderado o voto

\footnotetext{
158 Disponível no site da $\quad$ CVM <http://www.cvm.gov.br/port/inqueritos/2002/rordinario/inqueritos/TARJ2002_1153.asp>. Acesso em 10 de maio de 2011.
} 
vencedor no Processo Administrativo Sancionador CVM no TA/RJ2001/4977, o Caso TIM.

A diretora Norma, seguindo o entendimento de seu voto anterior, baseou sua argumentação na interpretação de que para a averiguação de conflito de interesses não seria necessário que os interesses sejam opostos, mas apenas que o acionista tenha duplo interesse no negócio. Porém, depois de ter esse argumento duramente combatido pelo diretor Luiz Antonio no Caso TIM, em resposta, Norma Parente aprofundou suas explicações sobre o conflitos de interesses:

“(...) tem-se que o conflito de interesses ocorre sempre que o acionista encontra-se em posição dupla frente à sociedade. Ao mesmo tempo em que ele possui o dever legal de votar em favor dos interesses da sociedade, surge o seu interesse privado na outra ponta, de modo que é impossível atender plenamente aos dois, sendo inevitável o sacrifício de um em nome do outro. Para evitar que o interesse social seja renunciado pelo acionista, a lei 6.404/76 impediu o mesmo de deliberar nas assembléias em que possa haver o conflito." (grifei) (voto Norma, p. 11)

Continuou sua argumentação fazendo uma diferenciação entre voto abusivo e o conflituoso. Para ela, no primeiro caso há, necessariamente, uma avaliação substancial do voto, a posteriori. Diferentemente do que ocorre na segunda hipótese, já que a verificação de tal situação se daria a priori.

Já o diretor Wladimir Castelo Branco Castro, seguindo seu novo entendimento, manifestou-se a favor da corrente materialista. Defendeu sua tese afirmando que não se deve partir da premissa de que o acionista não votou de boa-fé. Por isso, o conflito deveria ser apurado após o exercício do voto:

\footnotetext{
"A esmagadora maioria dos juristas entende que o efetivo conflito de interesse no exercício do voto deve ser expresso em uma vantagem auferida pelo acionista e, a meu sentir, não está devidamente caracterizado nos autos que os acionistas tenham votado com o intuito de obter qualquer vantagem para si."
} 
O voto do diretor Luiz Antonio de Sampaio Campos baseou-se numa análise da doutrina e da jurisprudência nacional e estrangeira, que o leva a afirmar, por fim, que "não está (...) comprovada a ocorrência de conflito de interesses, nem que o contrato aprovado seria lesivo ao interesse social." Já nas palavras do diretor-presidente Luiz Leonardo Cantidiano:

\begin{abstract}
"Olhando a parte final do $\S 1^{\circ}$, pelo outro lado, verifica-se que se a deliberação não puder beneficiar o acionista de modo particular e/ou se o seu interesse estiver sintonizado com o interesse da companhia ele estará admitido a votar. Ele poderá votar. Pois bem, no caso concreto o interesse da acionista Telemar e de suas acionistas indiretas, (que são os acusados PREVI e SISTEL), era a meu ver convergente com o interesse da companhia que obteria, em razão do contrato celebrado, uma assistência técnica de experientes e bem sucedidos empresários, o que proporcionaria melhor desempenho das atividades que as companhias operacionais adquiridas no processo de privatização pretendiam desenvolver."
\end{abstract}

Entendeu Cantidiano, inclusive, que a TELEMAR, ao abster-se de votar na deliberação em assembleia da TNLP, foi além do que a lei determinava. Poderia ela ter votado já que o voto estaria sendo dado numa situação que não configurava conflito de interesses e não lhe gerava benefício particular.

Note-se que este caso é bastante peculiar dada à composição da estrutura societária do grupo econômico em pauta. Como pode-se ver com mais clareza no Anexo 1, a participação direta dos fundos PREVI e SISTEL na TNLP era de meros 9,59\% à época da instauração do processo. Já a participação indireta dos fundos, fazia-se por meio da TELEMAR, controladora com 52\% das ações ordinárias da TNLP. A TELEMAR, por sua vez, tinha 19,89\% de suas ações ordinárias nas mãos da FIAGO, outra entidade controlada pelos fundos. Perceba-se que a PREVI e SISTEL, neste caso, sequer detinham a maior parte do capital votante da TELEMAR, daí as consequências de uma proibição de voto poderem ser imprevisíveis, como explorado mais adiante na Conclusão desta obra. 
Apesar da decisão fundamentada da autarquia de valores mobiliários, seu entendimento foi reformada por meio do Recurso 4585 proposto perante o CRSFN. O órgão recursal manteve o entendimento do julgado anterior (Caso TIM) de que a situação conflituosa no exercício de voto do acionista em assembleia se daria com base em aspectos meramente formais. No âmbito da CVM, contudo, o entendimento materialista continuou a prevalecer por anos, como veremos a seguir na análise do Caso AMBEV.

\subsubsection{O Caso AMBEV}

No dia 03 de março de 2004 foi anunciada a associação internacional da Companhia de Bebidas da América S.A. ("AMBEV") e Interbrew S.A. ("INTERBREW"). Essa reestruturação societária foi, à época, a maior operação do tipo em companhia aberta no Brasil. Este complexo negócio dividia-se, basicamente, em duas etapas:

$\mathrm{Na}$ primeira fase, houve uma permuta de ações entre os acionistas da Braco S.A. ("BRACO") - controladora da AMBEV - e a INTERBREW, que passou a ser denominada de Interbrew AmBev S.A. ("INBEV"). Esta companhia emitiu 141,7 milhões de ações em favor dos acionistas daquela. Em troca, a INBEV passou a deter diretamente as ações de BRACO controladora da AMBEV.

Acordou-se que na estrutura final do grupo econômico haveria uma sociedade Holding, a Stichting Interbrew S.A. ("STICHTING”). Essa companhia, era detida em $44 \%$ pelos antigos acionistas da BRACO e em 56\% pelos antigos acionistas da INBEV. Apesar da diferença na participação societária de cada um dos grupos, o controle da STICHTING seria 
compartilhado de forma equânime. A STICHTING, por sua vez, passou a deter o controle da INBEV, com $56 \%$ do seu capital. O restante ficou dividido entre os antigos acionistas da INBEV - com $18 \%$ - e o Mercado - com $26 \%$.

$\mathrm{Na}$ segunda etapa, realizada em paralelo, decidiu-se, por meio assembleia geral extraordinária realizada em 18 de maio de 2004, que a AMBEV emitiria 19,3 bilhões de ações em favor da INBEV em troca de 100\% das ações da Labatt Brewing Canadá Holding Ltd. ("LABATT”), empresa detida pela INBEV.

Ao final da operação, a AMBEV tinha 57\% do seu capital nas mãos da INBEV, de forma indireta. Do restante, $8 \%$ do capital eram detidos pela FAHZ - fundação ex-controladora da Companhia Antarctica Paulista S.A. - e 35\% do capital dispersos pelo Mercado. Para facilitar a visualização da estrutura final do grupo, veja-se o Anexo 2.

Em 08 de abril de 2004 a PREVI apresentou reclamação na CVM alegando que haveria irregularidades envolvendo as operações de permuta das ações e incorporação da LABATT. A SEP não acolheu a reclamação. O fundo interpôs, então, recurso perante a CVM. Alegava o fundo que houve, dentre outros, a prática de abuso de poder de controle e conflito de interesses no exercício de voto dos acionistas controladores da AMBEV na operação. Instaurou-se, assim, o Processo CVM no RJ2004/5494 ${ }^{159}$ para averiguar os fatos e fundamentos da reclamante.

A argumentação da PREVI baseava-se no fato de que a incorporação da LABATT era condição para a permuta de ações. Por isso, estariam os

159 Disponível no site da CVM <http://www.cvm.gov.br/port/descol/resp.asp?File=2004047ED16122004.htm>. Acesso em 10 de maio de 2011. 
controladores da AMBEV em conflito de interesses e não poderiam ter votado na deliberação que aprovou a incorporação.

No julgamento desse processo, ocorrido em 16 de dezembro de 2004, o Colegiado da CVM rejeitou a instauração de inquérito administrativo. Justificou-se a decisão pelo fato de não haver indícios de que a referida incorporação havia sido realizada segundo os exclusivos interesses da BRACO, em detrimento dos objetivos sociais e dos demais acionistas da AMBEV.

Relator do processo e líder do voto vencedor, o diretor Wladimir Castelo Branco Castro, mantendo o entendimento do julgado anterior, consignou que a verificação do conflito de interesses seria substancial e, portanto, comportaria um controle ex post do exercício do direito de voto pelo acionista.

Não obstante, defendeu, ainda, que o conflito de interesses, conforme previsto no parágrafo $1^{\circ}$ do artigo 115 da Lei das S.A., sequer poderia ser alvo de discussão no caso já que se tratava de incorporação de empresa sob controle comum. Ou seja, a incorporação da LABATT havia ocorrido quando a INBEV já havia se tornado acionista indireta da AMBEV e, consequentemente, a ter um acionista controlador comum. Aplicar-se-ia, portanto, o disposto no artigo 264, caput e parágrafo $4^{\circ}$ da Lei das S.A., que reconhece a submissão do interesse da companhia de controle comum ao interesse do grupo, afastando a incidência do parágrafo $1^{\circ}$ do artigo 115. O diretor Marcelo Fernandes Trinidade acolheu integralmente o voto do relator no que concerne a situação de conflito de interesses do acionista controlador. 
Já a diretora Norma Parente, mais uma vez divergindo do entendimento materialista, defendeu que a operação, apesar de realizada em fases distintas, deveria ser examinada em conjunto. Principalmente pelo fato de a incorporação, realizada posteriormente, depender intrinsecamente da permuta de ações, conforme o próprio contrato de contribuição e subscrição. Não se aplicaria, desse modo, o disposto no parágrafo $4^{\circ}$ do artigo 264 da Lei das S.A., mas o parágrafo $1^{\circ}$ do artigo 115 . Além disso, por entender que o conflito de interesses seria formal, como das vezes anteriores, acolheu a tese de que havia abuso de poder de controle e conflito de interesses no exercício do voto da BRACO.

\subsubsection{O Caso TRACTEBEL}

Em 21 de dezembro de 2009, a Tractebel Energia S.A. ("TRACTEBEL") divulgou fato relevante sobre a aprovação, por seu Conselho de Administração, da celebração de um contrato de compra de 99,99\% das ações de emissão da Suez Energia Renovável S.A. (“SER”), da GDF Suez Energy Latin America Participações Ltda. ("GDF"), sua acionista controladora. A proposta, conforme exigido pelo artigo 256 da Lei das S.A., seria encaminhada, ainda, para deliberação em assembleia geral extraordinária da TRACTEBEL.

Após ter solicitado esclarecimentos, a SEP determinou que a GDF deveria se abster de votar na assembleia que deliberasse sobre tal matéria, com base no disposto no parágrafo ${ }^{\circ}$ do artigo 115 da Lei 6.404/76. Para a superintendência, a acionista GDF não poderia participar da deliberação que aprovasse contrato com parte relacionada, já que poderia beneficiá-la de modo particular e estaria, ainda, em conflito de interesses com sua controlada. 
A TRACTEBEL, por sua vez, propôs recurso solicitando a revisão do entendimento manifestado pela SEP. Pretendia que fossem excluídas do impedimento à votação da acionista controladora, ao menos, as transações com partes relacionadas que foram negociadas por meio do comitê especial independente, criado nos moldes do Parecer de Orientação CVM n ${ }^{\circ} 35$.

No julgamento desse recurso, que originou o Processo Administrativo $\mathrm{n}^{\circ}$ RJ 2009-13179, realizado em 9 de setembro de 2010, prevaleceu no colegiado da CVM o entendimento de que a acionista controladora GDF não poderia participar da decisão sobre a celebração do contrato entre TRACTEBEL e outra empresa do grupo controlador. Inclusive, entendeu-se, por maioria de votos, que a criação de um comitê especial independente não seria suficiente para afastar o conflito de interesses na negociação.

O diretor relator Alexsandro Broedel Lopes, que liderou o entendimento do colegiado da autarquia, adotou, no julgamento do caso, a corrente formalista de conflitos de interesse. Para ele, a contratação entre a TRACTEBEL e GDF seria clara hipótese conflituosa. Apesar disso, segundo ele, o acionista controlador poderia votar se conseguisse fazer prova de que agiria, por algum instrumento de governança corporativa, em prol do interesse da TRACTEBEL. O comitê independente criado pela companhia, contudo, não atende a essa função já que só conta com membros da administração, quando o verdadeiro conflito se dá em face dos direitos dos acionistas minoritários que não foram convidados a participar do comitê.

Além disso, destaca que o Parecer CVM n 35 deixa expresso que sua aplicação é direcionada, especificamente, para as hipóteses tratadas no artigo 264 da Lei das S.A., que criou um regime especial para as operações de fusão, 
incorporação e incorporação de ações envolvendo sociedade controladora e controlada ou sob controle comum. Portanto, a criação do comitê independente, nos moldes do Parecer, não afasta a incidência do parágrafo ${ }^{\circ}$ do artigo 115 da lei societária.

A diretora Maria Helena Santana também defendeu que o acionista estaria impedido de votar. Entretanto, a justificativa para seu voto baseou-se no entendimento de que o caso em tela tratava de benefício particular para o acionista, já que o benefício da venda das ações que indiretamente lhe pertenciam, não poderia ser compartilhado com os demais acionistas. Alegou, ainda, que as consequências de sua decisão teriam impacto reduzido nas companhias de capital aberto já que a grande maioria das transações com partes relacionadas não é submetida à assembleia, sendo aprovadas exclusivamente no âmbito dos órgãos de deliberação.

Manifestou-se no mesmo sentido o diretor Otavio Yazbek que, apoiado nos ensinamentos de Fabio Konder Comparato, defendeu que o primeiro juízo sobre a situação de conflito de interesses deve ser feito pelo próprio acionista. Isto não quer dizer, contudo, que ele estaria livre para votar já que os acionistas minoritários poderiam, também, suscitar a questão na própria assembleia. Acrescentou, ainda, que caso a situação conflituosa não fosse verificada $a$ priori, ainda caberia a anulação do voto do acionista que o exerceu. Para ele, ainda que se deva presumir usualmente a boa-fé das partes, nada impede que a lei estipule regimes de prevenção, como seria o caso da proibição de voto constante no parágrafo $1^{\circ}$ do artigo 115 .

Além deles, o diretor Marcos Barbosa Pinto, manifestou-se no mesmo sentido, fazendo uma brilhante análise do conflito de interesses, abordou a evolução do entendimento jurisprudencial, sua interpretação à luz do 
ordenamento jurídico e, ainda, um estudo sobre eficiência econômica de cada uma das formas de interpretação.

O único voto em sentido contrário ao do relator foi o do diretor Eli Loria que, seguindo a corrente substancial, defendeu que se a operação estivesse sendo realizada de acordo com as práticas de mercado, não haveria motivos para a anulação do voto.

Por fim, não se pode deixar de mencionar o resultado da assembleia geral extraordinária de 19 de outubro de 2010, da qual a GDF se absteve de votar, conforme orientação da CVM: Foi nela aprovada, de forma unânime, a referida aquisição. 


\section{CONCLUSÃO}

Examinado o conflito de interesses, podemos tecer algumas considerações à guisa de conclusão. Dessa forma, tratemos doravante de responder à indagação mais elementar que vem à mente do leitor: de que tipo de conflito de interesses trata, afinal, a Lei das S.A.?

Como vimos, ambas as correntes - formal e material - se esforçam em apresentar argumentos em defesa de suas teses. Após uma análise mais aprofundada do estudo, todavia, fica evidente que a corrente formal não pode prosperar já que seus argumentos podem ser todos, um a um, descartados. Prevalece, assim, a corrente que me parece mais pertinente: a que se apóia na interpretação substancial do conflito de interesses.

O confronto entre as teses começa na própria definição do termo conflito. Conforme ficou demonstrado, para a configuração da situação conflituosa requer-se mais do que a simples oposição de interesses, como defende a tese formalista. Exige-se um sacrifício efetivo do interesse da companhia face ao interesse egoístico do acionista. Isso, por sua vez, não pode ser presumido, sob pena de se aleijar o Princípio da Boa-Fé. O sacrifício do interesse social deve ser provado por elementos materiais, requerendo, consequentemente, que se faça uma análise caso a caso do voto proferido pelo acionista em assembleia.

Nesse sentido, verificamos ainda a ratio legis do artigo 115 da Lei das S.A. que abarcou situações de atentado ao interesse social verificáveis, tanto por um critério subjetivo, como por um critério objetivo. Para o enquadramento no caput faz-se necessária a análise subjetiva do dolo, graças ao uso do termo com o fim de. Já no parágrafo $1^{\circ}$, elencaram-se critérios 
estritamente objetivos para a proteção do interesse social, a saber: (i) se ele for administrador, em casos de aprovação de contas; (ii) se for acionista contribuinte, para o caso de formação do capital social; (iii) se for acionista beneficiado, na hipótese de benefício particular; e, por último, (iv) se for acionista materialmente conflitado, em casos de conflito de interesses. Foi esse critério objetivo que fez o legislador brasileiro juntar no mesmo dispositivo legal tanto os casos de conflito formal - os três primeiros - como a cláusula genérica de conflito material - o último.

Apesar das críticas formalistas a essa diferenciação de comandos, restou evidente que o próprio legislador a admitiu ao direcionar o parágrafo $4^{\circ}$ do artigo 115 somente para a última hipótese do parágrafo $1^{\circ}$. Assim, diferentemente dos demais casos, possibilitou-se a anulação, a recuperação das perdas e danos e a devolução dos benefícios, às deliberações tomadas com conflito de interesses. Aos demais casos restou recorrer à nulidade.

Ressaltou-se nesta obra, além disso, a importância do respeito ao Princípio Majoritário, elemento basilar da organização democrática societária. Enumeraram-se, para isso, as perigosas consequências que uma interpretação formalística poderia acarretar. Exemplo disso seria a dependência excessiva em um pequeno número de acionistas minoritários - instáveis e que pouco contribuíram para a formação do capital social. Seria possível o legislador terlhes outorgado a competência para gerir os negócios da empresa? Parece-me que não seria justo, principalmente porque os resultados dessas decisões afetariam, sobretudo, àqueles que mais investiram nessa sociedade. Vimos, inclusive, que se tivesse tomado tal rumo, estar-se-ia abrindo espaço para o abuso dessas minorias, dificilmente contornável por processos judiciais. 
Percorremos também o histórico de entendimentos da CVM a respeito do conflito de interesses. Como se pôde perceber, a autarquia está longe de ter uma posição definitiva. Em dado momento, apega-se à corrente formal, em outro, agarra-se à tese material, variando, sobretudo, de acordo com a composição do seu colegiado. A CVM, dessa forma, já perpassou por três fases distintas.

Na primeira delas, evidenciada pelo julgamento do Caso TIM, em 2001, estudou-se a clássica ipotesi di scuola, como referiu-se Galgano ao dissertar sobre o conflito na contratação entre controladora e controlada. Nessa fase o órgão adotou a tese formalista do conflito de interesses, liderada pela exdiretora Norma Jonssen Parente, que continuou a defender seu entendimento em outros julgamentos posteriores.

Logo depois, em 2002, com a apreciação do Caso PREVI, a autarquia radicalmente mudou sua leitura do parágrafo $1^{\circ}$ do artigo 115 . Liderado pelo ex-diretor Luiz Antonio de Sampaio Campos, desconstruiu-se cada um dos argumentos formalistas, deixando evidente a prevalência da corrente material, tanto no âmbito nacional, como no internacional. Nessa fase atraiu-se, inclusive, novos adeptos à corrente material, tais como o ex-diretor Wladimir Castelo Branco Castro. Este entendimento substancialista continuou a prevalecer no órgão colegiado da autarquia por anos. Inclusive, foi reforçado pelo julgamento do Caso AMBEV, em 2004.

Mais recentemente, em setembro de 2010, no julgamento do Caso TRACTEBEL, o órgão colegiado da CVM, com sua nova composição, retrocedeu seu entendimento aos patamares de 2001. Determinou, assim, o impedimento de voto da acionista controladora da TRACTEBEL com base no conflito formal de interesses. Com esse comportamento instável, a CVM 
acabou por gerar enorme insegurança jurídica no mercado de capitas brasileiro, o qual deveria justamente proteger.

Como não podia deixar de ser, inúmeros autores insurgem-se contra tal decisão. Como visto, fora alguns poucos juristas, liderados por Modesto de Souza Barros Carvalhosa, a doutrina é hoje quase unânime na aceitação da tese material de conflito de interesses. Dentre eles, destacam-se José Luiz Bulhões Pedreira, Alfredo Lamy Filho - autores do anteprojeto da Lei das S.A.-, Erasmo Valladão Azevedo e Novaes França, Luiz Antonio Sampaio Campos, Nelson Eizirik, Fran Martins, Marcelo Lamy Rego e Luiz Gastão Paes de Barros Leães, este último cita Luigi Mengoni no trecho abaixo:

\begin{abstract}
"Aliás, como adverte Luigi Mengoni em magistral estudo sobre a matéria, a 'proibição de voto' como sistema de tutela do interesse social vem sendo restringida gradativamente a hipóteses excepcionais, em face das necessidades do mundo econômico moderno, caracterizado pela concentração empresarial. Nas relações entre sociedades controladoras e controladas, estas perdem grande parte de sua autonomia empresarial. (...) Daí a tendência a adotar um sistema de controle ex post do exercício de voto; fulminando-o quando, do conflito de interesse, resulte ele objetivamente idôneo a acarretar dano à sociedade ou a outros acionistas, ou perseguir vantagens indevidas, para si ou para outrem."
\end{abstract}

O Caso PREVI é emblemático. Nesse julgamento, o voto de Norma Jonssen Parente, evidenciou ainda mais os riscos que poderiam derivar da intransigente interpretação formalista. Como se viu, defendeu a ex-diretora da CVM que a PREVI e a SISTEL deveriam abster-se de votar na assembléia que deliberasse sobre a contratação das empresas em que detinham participação ínfima (Veja-se o Anexo 1):

"O conflito de interesses entre, de um lado, PREVI e SISTEL, e de outro, Tele Norte Leste Participações, é evidente. Os dois fundos de pensão possuem participação tanto

\footnotetext{
${ }^{160}$ Citado pelo diretor Alexsandro Broedel Lopes faço ao julgamento do Processo Administrativo ${ }^{\circ}$ RJ 2009-13179. Disponível no site da $\quad$ CVM <http://www.cvm.gov.br/port/descol/respdecis.asp?File=7190-4.HTM>. Acesso em 10 de maio de 2011.
} 
na controladora (TELEMAR PARTICIPAÇÕES S.A.), através da FIAGO PARTICIPAÇÕES, quanto na controlada (TNLP), de maneira direta, conforme se pode verificar de sua estrutura acionária, em 30.11.99, apresentada pela própria defesa, às fls. 100 do processo." 161

“(...) a lei brasileira é clara e proíbe liminarmente o voto ao acionista que estiver em conflito de interesse. A lei sequer permite que se discuta a significância do conflito. Simplesmente, havendo conflito, proíbe o voto. A lei tampouco excepciona a regra para permitir o voto em conflito desde que exercido no interesse da companhia. A lei é taxativa, seu teor não comporta exceções. A lei optou por liminarmente proibir o voto. (...) Portanto, a preservação da harmonia e segurança da atividade empresarial, também, impunham a medida preventiva."

Impedir o exercício do direito de voto de um fundo por deter participação minoritária em sociedades alegando que se trata de uma "proibição liminar" em prol da proteção do interesse da companhia, traz graves consequências que os formalistas insistem em negligenciar. Especialmente se considerarmos que os fundos de investimento têm hoje aplicações em inúmeras empresas no país, nos ramos mais diversos possíveis, algumas delas, inclusive, em sociedades que podem vir a contratar entre si.

Imaginemos a seguinte hipótese: A Paranapanema S.A. ("PARANAPANEMA") decide vender seu minério de ferro à Usinas Siderúrgicas de Minas Gerais S.A. ("USIMINAS"). Entretanto, observado que a PREVI possui $23,96 \%$ capital da primeira e $10,40 \%$ do capital da segunda ${ }^{163}$, de acordo com a corrente formalista, o fundo estaria impedido de votar em qualquer das assembleias que deliberasse sobre tal contratação.

Não é só. A PREVI estaria também "liminarmente proibida" de votar em qualquer contrato de compra e venda de minério da PARANAPANEMA

\footnotetext{
${ }^{161}$ Norma Jonssen Parente face ao julgamento do Inquérito Administrativo CVM no TA-RJ2002/1153. Disponível no site da CVM <http://www.cvm.gov.br/port/inqueritos/2002/rordinario/inqueritos/TARJ2002_1153.asp>. Acesso em 10 de maio de 2011.

${ }^{162}$ Norma Jonssen Parente face ao julgamento do Inquérito Administrativo CVM no TA-RJ2002/1153.

${ }^{163}$ Revista Valor, Grandes Grupos. dez. 2010.
} 
sob o risco de tentar barrar a contratação buscando tornar mais atraente o preço pago por sua siderúrgica, a USIMINAS. O mesmo valeria para a essa siderúrgica na compra de minério.

Vamos além. O BNDES Participações S.A. ("BNDESPAR"), como sabemos, é um dos maiores veículos de investimentos do país. Como tal, possui participação em empresas que muitas vezes concorrem entre si. Possui, por exemplo, 21,08\% do capital das Centrais Elétricas Brasileiras S.A. ("ELETROBRAS"), 26,41\% do capital da Companhia Paranaense de Energia (“COPEL"), 21,46\% da Light Energia S.A. ("LIGHT") e 8,42\% da CPFL Energia S.A. (“CPFL”). ${ }^{164}$

Poderia o BNDESPAR participar da deliberação sobre a implantação de um projeto capaz de alavancar a geração de energia de qualquer das companhias? Se seguirmos à risca o entendimento dos formalistas, conforme manifestado por Norma Parente, a resposta é clara: não. Segundo esse entendimento, por ter participação em empresas concorrentes, o BNDESPAR estaria formalmente conflitado e, consequentemente, impedido de votar em qualquer assembleia dessas companhias, sob o risco de privilegiar a concorrente. Impõe-se, assim, mais uma vez, a "proibição liminar" de que trata Norma Parente.

Desse modo, não é difícil imaginar a quantidade de impedimentos de voto que poderiam ser impostos aos fundos de investimento com base no conflito formal de interesses, considerando que tais fundos possuem investimentos tão vultosos e dispersos no mercado. Segundo a própria CVM,

${ }^{164}$ Revista Valor, Grandes Grupos. dez. 2010. 
os fundos de investimento são hoje cerca de metade dos participantes do mercado (10.999), com aplicações que superam $40 \%$ do PIB nacional. ${ }^{165}$

Inclusive, ao adotar o entendimento formalista, a CVM confronta-se com suas próprias normas. Vejamos abaixo, nesse sentido, o que diz o artigo $2^{\circ}$ da Instrução Normativa CVM no 391 de 16 de julho de 2003:

\begin{abstract}
"Art. $2^{\circ}$ - O Fundo de Investimento em Participações (fundo), constituído sob a forma de condomínio fechado, é uma comunhão de recursos destinados à aquisição de ações, debêntures, bônus de subscrição, ou outros títulos e valores mobiliários conversíveis ou permutáveis em ações de emissão de companhias, abertas ou fechadas, participando do processo decisório da companhia investida, com efetiva influência na definição de sua política estratégica e na sua gestão, notadamente através da indicação de membros do Conselho de Administração."166
\end{abstract}

Outro exemplo de conflito formal poderia ser o existente na deliberação que tratasse da nomeação do acionista controlador para compor o Conselho de Administração de uma empresa qualquer. Deveria ele se abster de tal votação? Mais uma vez, para manter a coerência com a tese formal, teríamos de alegar que sim. E não sobrevive o argumento dos formalistas de que esse caso seria excepcionalíssimo e, por isso, não haveria conflito de interesses. Alegando isso estão eles próprios insurgindo-se contra sua tese. Vejamos as palavras de Modesto de Sousa Carvalhosa nesse sentido:

\begin{abstract}
"Não se considera benefício particular que dê ensejo ao conflito de interesses, inibidor do exercício do voto, a eleição de acionista para cargos da administração ou fiscalização da companhia. Neste caso, é perfeitamente lícito que o acionista vote em si mesmo para o preenchimento do cargo. Entende-se que, na hipótese, não há
\end{abstract}

165 Disponível no site da CVM <http://www.cvm.gov.br/port/relgest/cvmra2005.pdf> e 〈http://www.cvm.gov.br/port/relgest/RelatórioGestão_CVM_2010.pdf〉. Acesso em 24 de maio de 2011. Relatório mais recente é de 2005.

166 Instrução Normativa CVM no 391 de 16 de julho de 2003. Disponível no site da CVM <http://www.cvm.gov.br/asp/cvmwww/atos/exiato.asp?File=\%5Cinst\%5Cinst391.htm>. Acesso em 10 de maio de 2011. 
benefício particular próprio, já que a eleição e o desempenho das respectivas funções fazem-se em favor da sociedade e não do acionista investido." 167

Ora, apesar do que disse Carvalhosa, não se pode negar que é sim possível o abuso do poder de controle por meio da indicação dos administradores. Veja-se, para comprovação inequívoca de tal fato, o que dispõe a Lei das S.A. no parágrafo ${ }^{\circ}$ do artigo 117:

“§ $1^{\circ}$ São modalidades de exercício abusivo de poder: (...)

d) eleger administrador ou fiscal que sabe inapto, moral ou tecnicamente;

e) induzir, ou tentar induzir, administrador ou fiscal a praticar ato ilegal, ou, descumprindo seus deveres definidos nesta Lei e no estatuto, promover, contra o interesse da companhia, sua ratificação pela assembléia-geral;

f) contratar com a companhia, diretamente ou através de outrem, ou de sociedade na qual tenha interesse, em condições de favorecimento ou não equitativas; (...)"

Como visto, nem sempre a eleição do administrador faz-se em benefício da companhia. Tal forma de abuso, note-se, é listada lado a lado à execução de um contrato com a companhia, constante do item "f". O próprio Modesto Carvalhosa se contradiz ao afirmar que as "vantagens ilicitamente perseguidas por meio do voto podem não ser meramente patrimoniais. Também as vantagens políticas com que se obtém o controle mediante a utilização abusiva de formas legais (...)."168

E os minoritários - em sua maioria pessoas físicas -, poderiam elas escapar aos rigorosos limites impostos por tal interpretação? Mais uma vez, para manter a coerência com a doutrina formal, a resposta deveria ser não.

${ }^{167}$ CARVAlHOSA, Modesto de Souza Barros. Comentários à Lei das Sociedades Anônimas. $3^{\mathrm{a}}$ ed. São Paulo: Saraiva, 2003. v. II, p. 467.

${ }_{168}$ CARVAlHOSA, Modesto de Souza Barros. Comentários à Lei das Sociedades Anônimas. $3^{\mathrm{a}}$ ed. São Paulo: Saraiva, 2003. v. II, p. 458. 
Exemplo que se pode dar é o de João Pereira, investidor que aplica suas pequenas poupanças em algumas poucas empresas por ele mais conhecidas, tais como a Petróleo Brasileiro S.A. ("PETROBRAS") e a OGX Petróleo e Gás S.A. ("OGX"), ambas do mesmo ramo. Da mesma forma que o BNDESPAR está impedido de votar na assembleia por deter participação em empresas concorrentes, João Pereira também o estaria, sob o risco de pretender privilegiar uma delas. O motivo para isso é que o parágrafo $1^{\circ}$ do artigo 115 , em momento algum, restringe sua aplicação aos acionistas controladores. Pode-se enquadrar, desse modo, qualquer minoritário.

As consequências negativas da interpretação da corrente formalista são infindáveis e por eles negligenciadas. Porém, parte da doutrina esmerou-se em apontar tais riscos. Veja-se, nesse sentido, o que têm a dizer José Luiz Bulhões Pedreira e Alfredo Lamy Filho:

"A pessoa que é acionista desempenha, simultaneamente, diversos outros papéis sociais, nos quais busca fins e tem interesses que são estranhos aos da companhia, ou com eles conflitam. Pode, por exemplo, ser administrador ou empregado da companhia, fornecedor de bens ou serviços adquiridos pela companhia ou comprador dos seus produtos, empresário de empresa concorrente, parente de algum de seus diretores ou seu acionista controlador. Ao prescrever o exercício do direito de voto no interesse da companhia, a lei proíbe ao acionista colocar a serviço de qualquer outro papel que ocupe um poder jurídico que é conferido para o desempenho da função de membro da Assembléia Geral. A caracterização do direito de voto como 'direito-função' e a distinção entre os atos do acionista enquanto sócio e como pessoa são outros modos de exprimir o mesmo princípio." ${ }^{69}$ (grifou-se)

Se, ainda assim, decidíssemos seguir a corrente formal, teríamos de aceitar que cada acionista formalmente conflitado estaria impedido de exercer seu direito de voto, não importando, para isso, se ele realmente quer exercer seu voto em prol da companhia. Não poderiam os fornecedores ou

\footnotetext{
${ }^{169}$ Citado por Luiz Antonio Sampaio Campos face ao julgamento do Inquérito Administrativo CVM $\mathrm{N}^{\circ} \quad$ TA/RJ2001/4977. Disponível no site da CVM <http://www.cvm.gov.br/port/inqueritos/2001/rordinario/inqueritos/4977.asp>. Acesso em 10 de maio de 2011.
} 
consumidores votar, tampouco os empregados da empresa, muito menos os acionistas ou o controlador contratantes e, além do mais, as pessoas vinculadas a cada um deles. Mas quem, afinal, poderia votar? Se seguíssemos à risca a tese formal, ao fim, não restaria mais ninguém. De alguma forma, todos os acionistas são direta ou indiretamente afetados pelas decisões da companhia.

O inevitável resultado do entendimento dos formalistas, por eles ignorado, seria agravar a redução do quorum de deliberação nas assembléias, estimulando, assim, o absenteísmo, sem mencionar a clara afronta ao Princípio Majoritário, ambos tratados no Capítulo 3.

A tese formal a respeito do conflito de interesses traz uma insegurança jurídica indesejável, já que se poderia levantar tal hipótese em qualquer deliberação, por qualquer motivo, inviabilizando, assim, o funcionamento das empresas e dos grupos empresariais. Este, claramente não era o objetivo do legislador. Vejamos, mais uma vez, a exposição de motivos da Lei das S.A., ${ }^{\circ}$ 196, de 24 de junho de 1976:

"O artigo 115 cuida dos problemas do abuso do direito de voto e do conflito de interesses entre o acionista e a companhia. Trata-se de matéria delicada em que a lei deverá deter-se em alguns padrões necessariamente genéricos, deixando à prática e à jurisprudência margem para a defesa do minoritário sem inibir o legítimo exercício do poder de maioria, no interesse da companhia e da empresa." $" 170$

Ora, a CVM deveria justamente tratar de evitar tal situação. Inclusive, a função de proteger o mercado de capitais e seus partícipes consta no artigo $4^{\circ}$ da Lei 6.385 que, como visto, criou a CVM:

“Art . 4 ${ }^{\circ} \mathrm{O}$ Conselho Monetário Nacional e a Comissão de Valores Mobiliários exercerão as atribuições previstas na lei para o fim de:

\footnotetext{
${ }^{170}$ Disponível no site da CVM <http://www.cvm.gov.br/port/atos/leis/6404_Exposicao.asp>. Acesso em 10 de maio de 2011.
} 
I - estimular a formação de poupanças e a sua aplicação em valores mobiliários;

II - promover a expansão e o funcionamento eficiente e regular do mercado de ações, e estimular as aplicações permanentes em ações do capital social de companhias abertas sob controle de capitais privados nacionais;

III - assegurar o funcionamento eficiente e regular dos mercados da bolsa e de balcão; (...)"171

Os romanos já nos ensinavam as consequências da summum jus, summa unjuria. Em outras palavras, a aplicação rigorosa da lei pode ensejar injustiças. Um bom jurista dedica-se, sobretudo, a buscar a verdadeira mens legis, antes de ater-se à estrita literalidade do dispositivo legal.

O parágrafo $1^{\circ}$ do artigo 115 da Lei das S.A. não proíbe o exercício do direito de voto do acionista formalmente conflitado. Lida sistematicamente, podemos entender que a lei busca combater o conflito material. Seu objetivo não é, portanto, criar novas restrições ao exercício do direito de participação política do acionista, mas evitar que ele possa se beneficiar ilegalmente sem ser punido por isso ou sem ter de ressarcir a empresa pelas perdas e danos.

Por tudo o que foi exposto, apesar de alguns poucos ainda insistirem em defender a coerência dos argumentos da tese formal, fica claro, após uma cuidadosa análise, tanto da Lei, como das consequências práticas de tal interpretação, que a melhor e mais pertinente alternativa é a interpretação material do conflito de interesses.

\footnotetext{
${ }^{171}$ Disponível no site do Planalto <http://www.planalto.gov.br/ccivil_03/Leis/L6385.htm>. Acesso em 10 de maio de 2011.
} 


\section{BIBLIOGRAFIA}

ASCARELLI, Túllio. Problemas das sociedades anônimas e direito comparado. $2^{\text {a }}$ ed. São Paulo: Saraiva, 1969. 22 p.

BARROS LEÃES, Luiz Gastão Paes de. Estudos e Pareceres sobre Sociedades Anônimas. São Paulo: Revista dos Tribunais, 1989. 9 p.

BATALHA, Wilson de Souza Campos. Comentários à Lei das Sociedades Anônimas. $1^{a}$ ed. Rio de Janeiro: Editora Forense, 1977. v. 2. 13 p.

BORBA, José Eduardo Tavares. Direito Societário. $9^{\mathrm{a}}$ ed. Rio de Janeiro: Renovar. 23 p.

BUGARELLI, Waldirio. Manual das Sociedades Anônimas. $4^{a}$ ed. São Paulo: Atlas, 1987. $9 \mathrm{p}$.

BULHÕES PEDREIRA, José Luiz; LAMY FILHO, Alfredo. Direito das Companhias. $1^{a}$ ed. Rio de Janeiro: Forense, 2009. v. I, 95 p.

BULHÕES PEDREIRA, José Luiz; LAMY FILHO, Alfredo. A Lei das S.A...1 ed. Rio de Janeiro: Renovar. v. II, 127 p.

CAMPOS, Luiz Antonio Sampaio. Direito das Companhias. $1^{a}$ ed. Rio de Janeiro: Forense, 2009. v. I, 18 p.

CARVAlHOSA, Modesto de Souza Barros. Comentários à Lei das Sociedades Anônimas. $3^{\mathrm{a}}$ ed. São Paulo: Saraiva, 2003. v. II, 56 p. 
CARVAlHOSA, Modesto de Souza Barros. Problema Flagrante. Revista Capital Aberto. São Paulo, p. 30, jan. 2011.

CARVAlHO SANTOS, J.M. de. Código Civil interpretado. $6^{a}$ ed. Rio de Janeiro: Freitas Bastos, 1958. v. 15. 5 p.

COELHO, Fábio Ulhoa. Curso de Direito Comercial. $8^{\mathrm{a}}$ ed. São Paulo: Saraiva. v. II, $24 \mathrm{p}$.

COMPARATO, Fabio Konder; SAlOMÃO FILHO, Calixto. O Poder de Controle na Sociedade Anônima. $4^{\mathrm{a}}$ ed. Rio de Janeiro: Forense. 113 p.

DIAS, Rui Manuel Pinto Soares Pereira. Responsabilidade por Exercício de Influência Sobre a Administração de Sociedades Anônimas: Uma análise de direito material e direito de conflitos. ed. única. Coimbra: Edições Almedina, 2007. 12 p.

DINIZ, Maria Helena. Código Civil Anotado. $11^{\mathrm{a}}$ ed. São Paulo: Saraiva, 2005. 15 p.

EIZIRIK, Nelson. Mercado de Capitais, Regime Jurídico. $2^{a}$ ed. Rio de Janeiro: Renovar. 2008. 122 p.

EIZIRIK, Nelson. Temas de Direito Societário. $1^{\text {a }}$ ed. Rio de Janeiro: Renovar, 2005. $39 \mathrm{p}$.

FRANÇA, Erasmo Valladão Azevedo e Novaes. Conflito de Interesses nas Assembléias de S.A.. ed. única São Paulo: Malheiros, 1993. 88 p. 
FRANÇA, Erasmo Valladão Azevedo e Novaes. O que vale é a substância. Revista Capital Aberto. São Paulo, p. 31, jan. 2011.

GREGÓRIO, Danilo; AZEVEDO, Simone. No mesmo barco. Revista Capital Aberto. São Paulo, p. 56, nov. 2010.

MARTINS, Fran. Comentários à Lei das Sociedades Anônimas. $2^{a}$ edição. Rio de Janeiro: Forense, 1984. 75 p.

MAXIMILIANO, Carlos. Hermenêutica e aplicação do direito, Rio de Janeiro: Forense, 2002. $47 \mathrm{p}$.

OLIVEIRA, Fernando A. Albino de. Poder Regulamentar da Comissão de Valores Mobiliários. São Paulo, 1989. 36 p.

REGO, Marcelo Lamy. Direito das Companhias. $1^{\mathrm{a}}$ ed. Rio de Janeiro: Forense, 2009. v. I, 52 p.

REQUIÃO, Rubens. Curso de direito comercial. 21 a ed. São Paulo: Saraiva, 1995. v. 1.12 p.

Boletim de Jurisprudência. Revista Capital Aberto. p. 34, nov. 2010.

Dicionário Aurélio Buarque de Holanda Ferreira: conflito.

Dicionário Antônio Houaiss: conflito.

The New Encyclopadia Britannica, ed. 15. 1986., vol. 3, p. 529. 
Revista Valor, Grandes Grupos. dez. 2010.

\section{Sites:}

The Cardozo Electronic Law Bulletin. Disponível em <http://www.jus.unitn.it/cardozo/obiter_dictum/codciv/codciv.htm>. Acesso em 10 de maio de 2011.

Site do Planalto: 〈http://www.planalto.gov.br>. Acesso em 10 de maio de 2011.

Site da CVM: <http://www.cvm.gov.br>. Acesso em 10 de maio de 2011. 


\section{ANEXO 1}

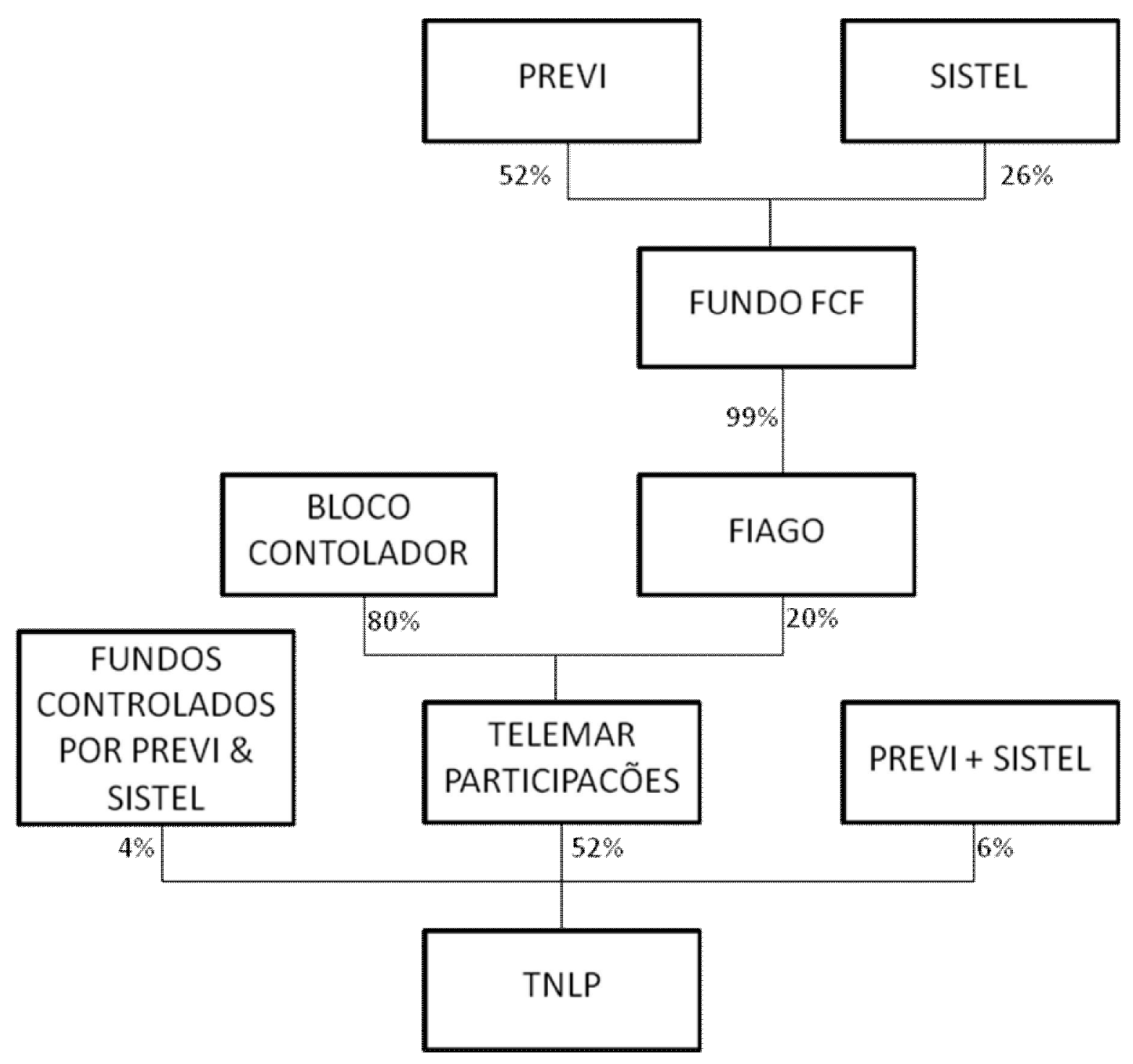




\section{ANEXO 2}

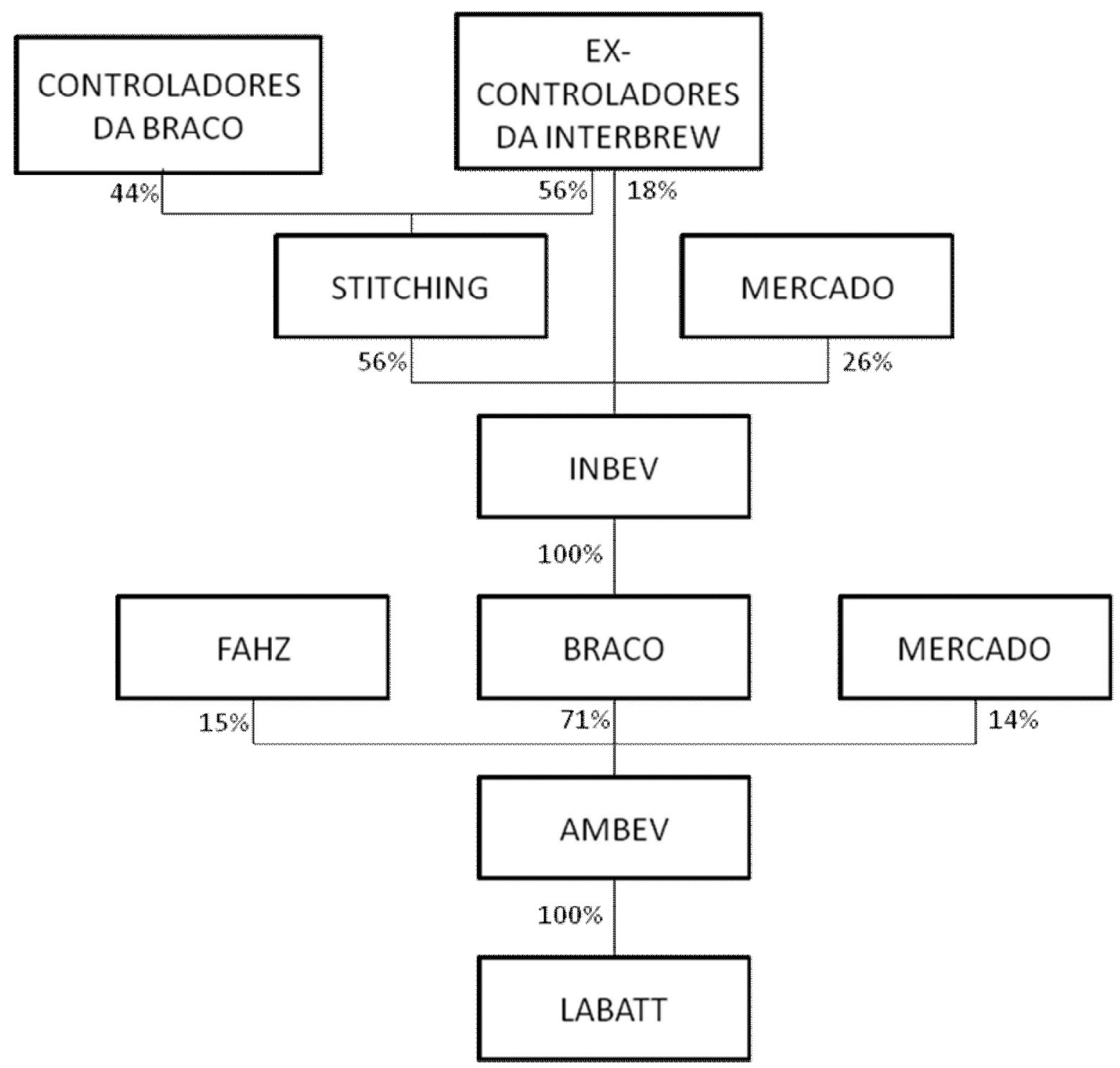

